\title{
THE RURAL PROBLEM
}

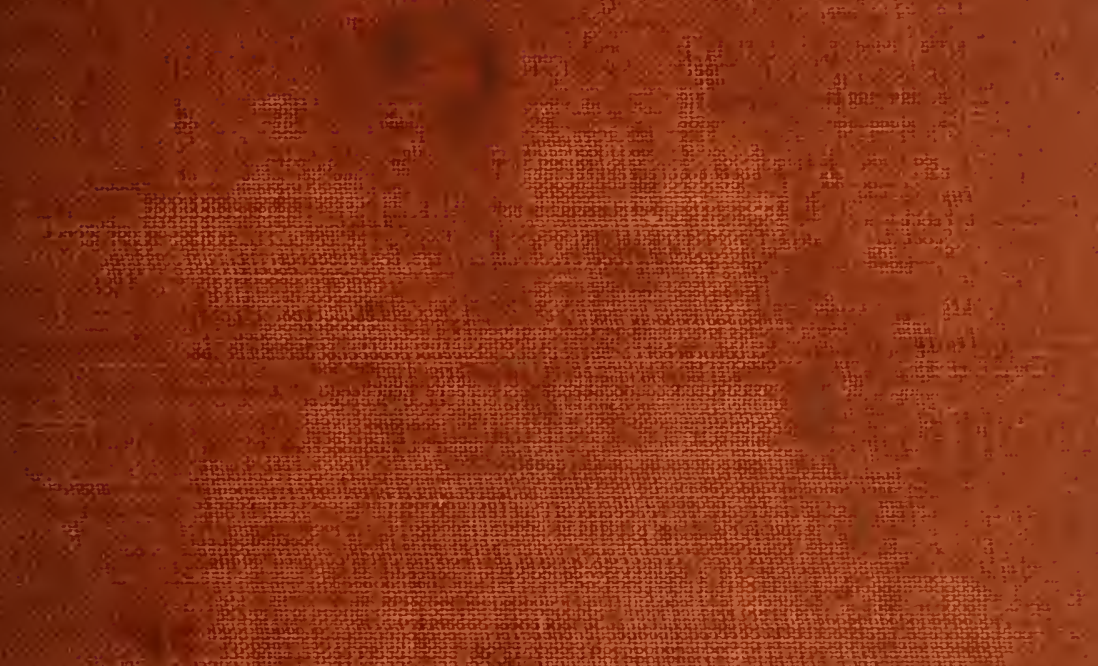

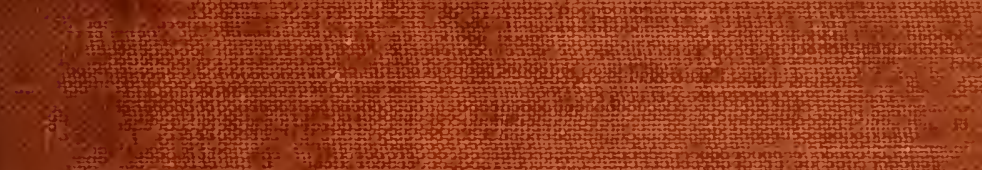

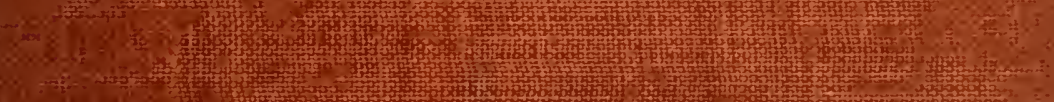

Fin

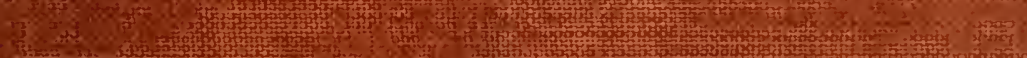

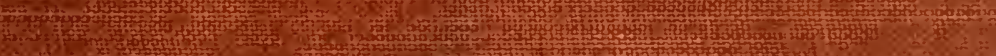
Y

Trow

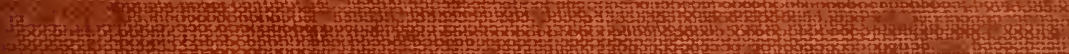
This

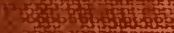

\section{WHNYY D IIRBบ}

西 a

1.

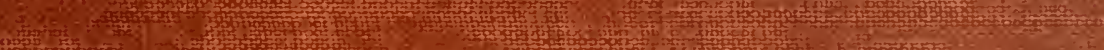
X 


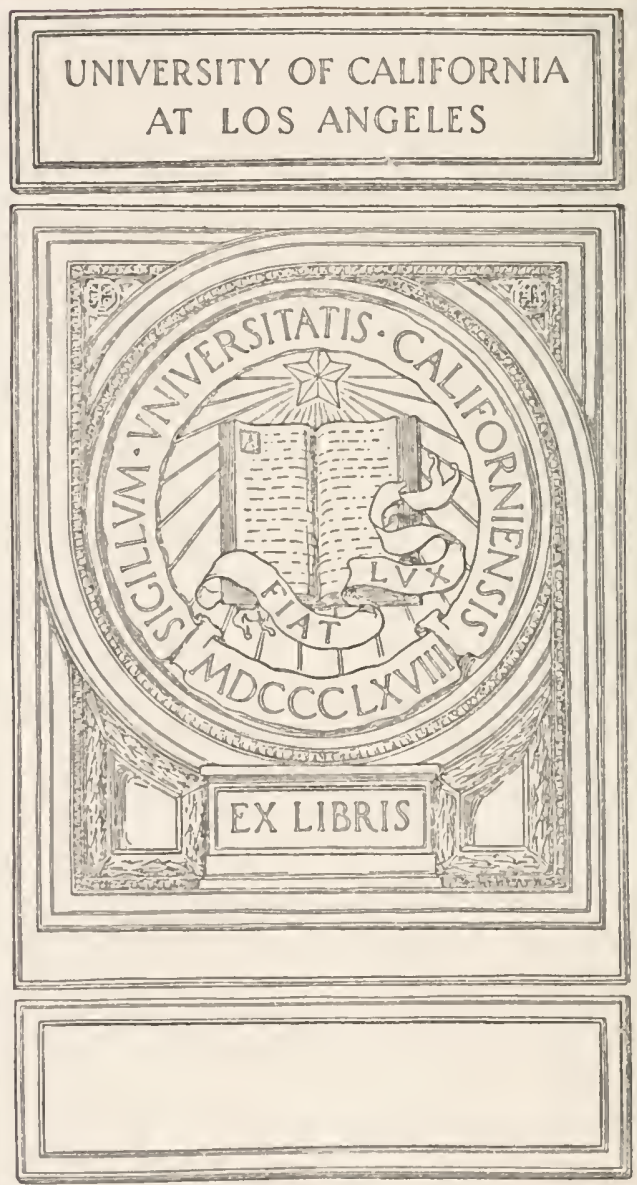





\section{Digitized by the Internet Archive in 2008 with funding from Microsoft Corporation}




\section{The RURAL PROBLEM}





\section{The}

Rural Problem

By

HENRY D. HARBEN

LONDON

CONSTABLE \& COMPANY LTD

I 9 I 3 
W. H. Smith \& SoN,

55 Fetter Lane, London, E.C. 


\section{PREFACE}

T $\mathrm{N}$ the autumn of 1912 the Fabian Society formed a Comnittee to inquire into Land Problems and L Rural Development, and to report to the Society upon the whole subject. The members of the Committee included men and women with a very spccial knowledge of certain aspects of country life. They heard the evidence of witnesses of varying shades of political and economic opinion, and consulted many of the leading living authoritics on different branches of the subject.

It fell to my lot, as Chairman of this Committee, to draw up a Report, the original draft of which appeared in August as a special supplement to Tine New Statesmax. The draft, with some correction and modifications, and witli the addition of numerous appendices, was afterwards adopted as the Report of the Committee ; and it is this Report which is now made public in the following pages. One menber, Mr. Oldershaw, disagreed with the Minimum Wage policy, especially as regards its effect on the farmer; the rest of the Comnittee were at one on all the main issues. It was intended to include a chapter on Women in Agriculture, but the facts were so difficult to obtain that we decided mercly to draw attention to the crying need for further official infornation. 
Athough personally responsible for the Report, I am indebted to the work of my colleagues on the Cominittee for most of the information it contains. Wliere so many helped it is impossible to thank them all; but I feel bound to acknowledge the valuable memoranda prepared by Mr. and Mrs. E. R. Pease, Mr. H. R. Gledstone, Mr. C. M. Grieve, Mr. R. A. Bray, I.C.C., Mr. Hugh Aronson, and Mr. G. P. Blizard, parts of which have been incorporated in the present rolune. I am particularly indebted also to Mr. Sidney Webb for many useful suggestions, to Miss Gertrude Wrestbrook for preparing the bibliography, and to the Secretary of the Committee, Captain A. Imbert-Terry, for his constant help, not only during the inquiry, but also in preparing the Report.

The Land Question is likely to be much diseussed on public platforms and in the Press during the next few years. This volume claims to be a scrious contribution to the diseussion. We have tried to present in a handy form facts and figures up to date on many aspects of the question, and we hope that these will render the book useful even to readers who may differ from some of the conclusions we have based upon them.

(Signed) Henty D. Marben.

September, 1913. 


\section{CONTENTS}

PAGE

CHAPTER I.-The Dechine of the Countryside $\quad \ldots \quad 1$

CHAPTER II.-The Poverty of the LAbourer $\quad \ldots \quad 7$

Wages-Hours of Labour-Other Family EarningsThe Cost of Living in Agricultural Districts-The Cottage Question.

CHAPTER III.-A Minimum Wage for Agriculture...

The Case for Legislation-The Machinery-The Amount of the Wage-The Effect on the Farmer-The Effect on the Landlord.

Chapter IV.-The Solution of the Cottage

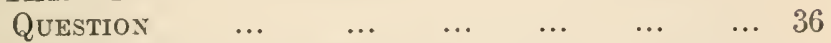

The Existing Law-The Financial Problem-A Government Housing Grant.

CHAPTER V.-Towardos Natioxalisation

Sentimental Value-Land Purchase-The Irredeemable Mortgage.

CHAṔTER VI.—Small Holdings $\ldots \quad \ldots \quad \ldots$

The Case for Small Holdings-The Small Holdings ActThe Limitations of Small Holdings.

CHAPTER VII.-Tenancy versus OWNership $\quad \ldots \quad \ldots 66$

CHAPTER VIII.EDUCATION $\quad \ldots \quad \ldots 6$.

CHAPTER IX.-The Organisation of Production $\ldots 73$

Co-operation-The Agricultural Organisation Society

-Co-operative Purchase-Co-operative Dairies and Factories-Credit Banks.

CHAPTER X.-The Organisation of Distribution ...

Co-operative Marketing-The Nationalisation of Railways-A State Motor Service. 
CHAPTER XI.-GAME

The Problem-The Abolition of the Game Laws-Tax on Game-preserving.

$\begin{array}{lllllll}\text { CHAPTER XII.-AFForestation } & \ldots & \ldots & \ldots & \ldots & 105\end{array}$

CHAPTER XIII.-RATES $\ldots$...

CHAPTER XIV.-Summary of Reconmendations _.. 112

APPENDIX A.-Compara'tive OUtput of Agriculture $\begin{array}{llllllll}\text { AND INDUSTRY } & \ldots & \ldots & \ldots & \ldots & \ldots & \ldots & 113\end{array}$

APPENDIX B.-Wages of Agricultural Labourers ... 115 APPENDIX C.-Report of an Investigator on Wages

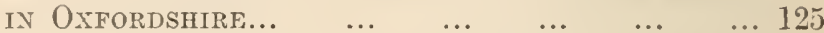

APPENDiX D.-History of Allotwents... $\quad \ldots \quad \ldots 127$

APPENDIX E.-Report by ax Ixvestigator ox a Soutil of Exgland Village $\ldots$... $\ldots$.

APPENDiX F.-State Action in Fixisg Wages... ... 131

APPENDiX G.-Table Showing Number of Labolrers Euployed ON TExant Farms axd Number OF ACRES PER LABOURER ... $\quad$...

APPENDIX H.-ReNt Per ACre of Tenayt Farus $\quad \ldots 137$

APPENDIX I.-Cost of Bullding Ix 1911 and 1913 ... 146

APPENDIX J.-Mendelism añd Agriculture $\ldots . \quad \ldots 147$

APPENDIX K.-EXTract Fron the A RTicles of AssoCiatiox of the Agricultural Organisation $\begin{array}{llllllllll}\text { SacIETY } & \ldots & \ldots & \ldots & \ldots & \ldots & \ldots & \ldots & 150\end{array}$

APPENDIX L.-EXPORTS OF DAIRY Produce From

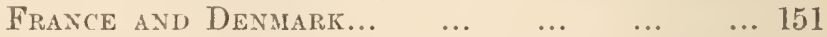

APPENDIX M.-Grants in Ain of Local Authorities $\begin{array}{lllllllll}1912-13 & \ldots & \ldots & \ldots & \ldots & \ldots & \ldots & \ldots & 153\end{array}$

$\begin{array}{lllllllll}\text { Bibliography } & \ldots & \ldots & \ldots & \ldots & \ldots & \ldots & \ldots & 155\end{array}$

$\begin{array}{llllllllll}\operatorname{INDEX} & \ldots & \ldots & \ldots & \ldots & \ldots & \ldots & \ldots & \ldots & 163\end{array}$ 


\section{CHAPTER 1.}

\section{THE DECLINE OF THE COUN'TRYSIDE.}

CO much attention has been given, of recent years, by politicians and by social workers to the condition of life in our erowded urbin areas, so much importance has been rightly attached to the development of our manufacturing industries, that the problems of country life and the interests of agrieulture have been foreed into the background. The reason of this is obvious. In England and Wales the population of urban districts* in 1911 was 28,162,936, as against a population of 7,907,556 in rural districts. The total output of the agrieultural land of Great Britain in 1907 was worth about $£ 210,000,000$, while in the same year the output of industry was about $£ 1,240,000,000$, or nearly six times as much. $\dot{\varphi}$

But although the comparative importance of the town may be increasing, the country still is, and ever must be, the home of millions of persons, the brecding-ground of millions of children. And although agriculture is now, and is likcly to remain, of far smaller importance than the urban industries, it still employs far more people than any other single industry. Moreover, the problems of the country are not localised, nor confined to a corner ; but are co-cxtensive with the whole area of the country, and are intinatcly bound up with our national life and health. The total extent of the land of England is $32,394,210$ acres, and of Vales 4,749,651; total, 37,143,861 acres, of which not less than 28,565,861 in England and 4,283,318 in Wales are agricultural landtotal, $32,849,1 \% 9$ acres, or $88^{\circ}+$ per cent. of the whole.t

While, therefore, it is foolish to regard the decline of agriculture with the despair which fills the heart of a Suffolk yeoman or a Wiltshire farmer, it is equally blind to be

* Census of England and Wales, 1911. Vol. I. (Cd. 625S, 1912.)

† See Appendix A.

¥ See Acreage and Live Stock Returns, Agricultural Statistics, 1912. Cd. 6.597 . 
indifferent, as is the average town politician to-day, to the enormous importance, racial and financial, of rural problems, to the pitiful waste of life and wealth that is going on unheeded all over the countryside.

The main symptoms of this decline are twofold. In the first place there has been an aetual decrease in the number of people engaged in agriculture. The report of the Board of Agriculture and Fisheries on this subject, published in 1906, says: "The reduetion in the number of persons returned as engaged in agriculture in Great Britain has been one of the most prominent features of the Census returns for the past 50 years, and it has never been more apparent than in the figures for 1901, when a decline of about 20 per cent. in the number of agricultural labourers during the preceding decade was indicated . . ."; and it goes on to say " the tenour of the majority of the reports indieates that sinee 1901 there has been some further reduetion in the number of men employed in farms, but the diminution is proceeding at a slower rate than during the 10 or 20 years preceding that date." *

It is not possible to give exact comparative tables for the past hundred ycars, because the Census returns beforc $\mathbf{1 8 5 1}$ give the number of families chiefly employed in agriculture, whereas the more recent returns give the number of persons. The following tables emphasise the extent of the actual decline :

Numeer fagaged in Agrictiture, United Kingdon, 1831-1901. $\dagger$ Table 1.-Agriculture (England and Wales) (p. 40).

\begin{tabular}{|c|c|c|c|c|}
\hline Census Year. & $\begin{array}{l}\text { Males ensaged } \\
\text { in Abriculture. }\end{array}$ & $\begin{array}{c}\text { Prop. per cent. } \\
\text { of total males } \\
\text { aged } 10 \text { and up- } \\
\text { wards. }\end{array}$ & $\begin{array}{l}\text { Females encaged } \\
\text { in Agriculture. }\end{array}$ & $\begin{array}{l}\text { Prop. per cent. } \\
\text { of total fcinales } \\
\text { aged } 10 \text { and up- } \\
\text { wards. }\end{array}$ \\
\hline 1831 & - & $31 \cdot 51$ & - & - \\
\hline 1841 & - & 25.93 & - & - \\
\hline 1851 & $1,544,08 \tau$ & $23 \cdot 5$ & 168,652 & $2 \cdot 4$ \\
\hline 1861 & $1,589,965$ & $21 \cdot 2$ & 115,213 & $1 \cdot 5$ \\
\hline $18 \% 1$ & $1,371,304$ & $16 \cdot 8$ & 85,967 & $1 \cdot 0$ \\
\hline 1881 & $1,288,173$ & $13 \cdot 8$ & $6,4,216^{\circ}$ & $0 \cdot f)$ \\
\hline 1891 & $1,233,936$ & $11 \cdot 6$ & 51,045 & 0.4 \\
\hline 1901 & $1,153,18.5$ & $0 \cdot \pi$ & $: 38,982$ & $0 \cdot 3$ \\
\hline
\end{tabular}

* Cd. 327\%, 1906.

† The Progress of the Nation, by G. IR. Pontek. New Edition, up to date, by F. WV. IIrRST, 191\%. 
Table 2.-Proportion borne by Males engagerl in Agriculture to tolal Male Population of 10 and upreards.

\begin{tabular}{c|c|c|c|c}
\hline Year. & United Kingdom. England \& Wales & Scotland. & Ireland. \\
\hline 1881 & $18 \cdot 8$ & $13 \cdot 8$ & $14 \cdot 4$ & $46 \cdot 0$ \\
1891 & $16 \cdot 2$ & $11 \cdot 6$ & $12 \cdot 7$ & $45 \cdot 7$ \\
1901 & $13 \cdot 6$ & $9 \cdot 5$ & $10 \cdot 7$ & $4.4 \cdot 3$ \\
\hline
\end{tabular}

The number of "Agricultural Labourcrs and Shepherds," which affords a more precise index, deelined in a still more marked degree.

$$
\begin{array}{rrrrrrrr}
1851 & \ldots & \ldots & 1,110,311 & 1881 & \ldots & \ldots & 830,452 \\
1861 & \ldots & \ldots & 1,098,261 & 1891 & \ldots & \ldots & 756,557 \\
1871 & \ldots & \ldots & 923,332 & 1901 & \ldots & \ldots & 609,105
\end{array}
$$

Secondly, there is the accompanying decrease in the population of the rural distriets. Again it is difficult to give exact figures, as almost every Census has had a different method of dividing its areas, and " rural " districts in the Blue Book are not always really rural. But the following table, even after making all necessary qualifications, tells a shocking tale, showing, as it does, a decrease of over a million in the rural population of England and Wales alone:

Census Returns, England and Wales, 1551-1911. Comparison of Urban and Rural Population, 1851-1911.*

Table 4.-England and Wales and its Sub-divisions into Urban and

\begin{tabular}{|c|c|c|c|c|c|}
\hline \multirow[t]{2}{*}{ : } & \multicolumn{3}{|c|}{ POPULATION. } & \multicolumn{2}{|c|}{$\begin{array}{l}\text { Prop. per cent. to total } \\
\text { Pop. of Eng. \& Wales. }\end{array}$} \\
\hline & $\begin{array}{l}\text { England and } \\
\text { Wales. }\end{array}$ & $\begin{array}{l}\text { Urban Districts } \\
\text { (as existing at } \\
\text { each Census). }\end{array}$ & $\begin{array}{l}\text { Rural Districts } \\
\text { (as existing at } \\
\text { each Census). }\end{array}$ & $\begin{array}{c}\text { Urban } \\
\text { Districts. }\end{array}$ & $\begin{array}{c}\text { Rural } \\
\text { Districts. }\end{array}$ \\
\hline $1851 \dagger$ & $17,927,609$ & $8,990,809$ & $8,936,800$ & $50 \cdot 2$ & $49 \cdot 8$ \\
\hline $1861 \dagger$ & $20,066,224$ & $10,960,998$ & $9,105,226$ & $54 \cdot 6$ & $45 \cdot 4$ \\
\hline $1871 \dagger$ & $22,712,266$ & $14,041,404$ & $8,670,862$ & $61 \cdot 8$ & $38 \cdot 2$ \\
\hline 1881 & $25,974,439$ & $17,636,646$ & $8,337,793$ & $67 \cdot 9$ & $32 \cdot 1$ \\
\hline $1891 \ddagger$ & $29,002,525$ & $20,895,504$ & $8,107,021$ & $72 \cdot 0$ & $28 \cdot 0$ \\
\hline $1901^{\top}$ & $32,527,843$ & $25,058,3 \tilde{\jmath}$ & $7,469,488$ & $7 \% \cdot 0$ & $23 \cdot 0$ \\
\hline 1911 & $36,070,492$ & $28,162,936$ & $\tau, 907,556$ & $78 \cdot 1$ & $21 \cdot 9$ \\
\hline
\end{tabular}
Rural Districts, as existing at each Census. Population and Proportion per cent. to Total Population, 1851-1911.

* Census of Eingland and Wales, 1911. Vol. I. Cd.6258, 1912. 5s.4d. + The figures for the aggregate of Urban and Rural areas for the Censuses of 1851-71 are only approximations.

+ The figures for 1891 refer to the areas as they existed at the date of publication of the report. 
The Census of 1911 shows a decrease in the population of the rural portions of several counties since 1901, as, for instance, by 2,725 in Cornwall, 1,138 in Herefordshire, and 1,286 in Radnorshire, amounting in this last case to a decrease of $7 \cdot 1$ per cent.*

Private inquiries reveal an even more striking decline in the prosperity of individual villages. Cerne Abbas, in Dorsetshire, where no new cottages have been built for over half a ecntury, presents an cxtraordinary instance in point.

Census of Inhabitants of Cerne Abias, Dorset.

$\begin{array}{lllllc}1821 & \ldots & 1,060 & 1881 & \ldots & 925 \\ 1831 & \ldots & 1,209 & 1891 & \ldots & 834 \\ 1841 & \ldots & 1,341 & 1912 & \ldots . & 585 \\ 1851 & \ldots & 1,343 & & & \text { (including } 46 \text { in } \\ 1861 & \ldots & 1,164 & & & \\ \text { workhouse). }\end{array}$

This decline in the rural population has been hastened by the miserable plight in which the workers of the land have found themselves, and which it will be the object of subsequent chapters to examine and describe. Owing to low prices and diminished eapital, the farmers altered their methods of farming with a view to conomising labour. The laying down of land to grass and the loss of two million acres of arable land threw out of work at least 60,000 to 80,000 labourers in the twenty years 1881-1901. A still greater displacement was eaused by the extended use of labour-saving machinery on the fifteen million acres still remaining under the plough. The substitution of mechanical for hand labour in threshing machines, chaff-cutters, pumps, ete., and the greatly increased use of drills, mowers, binders, manure distributors, and the like, have more than counterbalaneed any extension of dairy farming and market gardening.

Side by side with the displacement of labour in the country the ever-inereasing demand for workers in the towns has attracted all the energy and enterprise from the villages into the urban eentres. The carcer of the agricultural labourer offers at best little seope for ambition, and at worst a drudgery unequalled for its monotony and wretehedness. Not only is there little chance either for himself or for his children to raise themselves into a position of comparative

* Cd. 6258, 1912. 
seeurity, but often the barest necessities of life are denicd them. The wage of the labourer is seandalously low, his hours of work intolcrably long, his chances of recreation negligible. His cottage often belongs to his employer, and however ramshackle, unhealthy, or overerowded it may be, there is usually no other aviliable for miles around. 'There is no milk to be bought for his habies, even could he afford to buy it. 'T'here is no opening for his sons and daughters. The condition of his existence is one of servility and dependence upon others, against which any relic of spirit he possesses must rebel in vain.

And yet he knows better than anyone else that much of his suffering is wanton and mnecessary. He can sce that the land around him is either not fully utilised or is put to purely selfish uses which are of no benefit to the community as a whole. He knows that food could be grown on land which is now languishing for lack of capital or enterprise, that productive labour could be employed where now the gamekecper wanders with his gun and dog. Not until this knowledge of his is borne in upon the convictions of the rest of the community, not until the nation (with its fuller powers and truer sense of proportion) determines to take the rural problem as seriously as he does, will his unnecessary wrongs be righted, and a weak point be made strong again in the armour of our national life.

Sir; Horace Plunkett, the greatest agricultural reformer of our time, has maintained that the industrial revolution, as it has taken place in Great Britain and Amcrica, has destroyed the healthy relations of town and country populations, and that, in consequence, the civilisation of these countries has become dangerously one-sided. The tendeney, as civilisation advanees, for industry to displace agriculture, and for the mechanic to replace the peasant, is not necessarily regrettable, and it is a tendeney which it would be futile to attempt to arrest. But it carries with it the need of new ideals. The pieture of a country peopled with a prosperous peasantry must give way to that of a population mainly of well-paid mechanics and artisans with full access to the land, cnjoying with their families the health and beaty which slum life destroys, the recreation and activities 
which abound in mountain, field, and wood. And side by side with this picture must be one of a country life movement on the land itself which shall prevent agriculture and all that it represents in the national life bcing smothered by the neglect of our urban rulers. The status of the countryman must be raised and his opportunities inereased, the methods of agriculture must be revised in the light of modern knowledge and requirements, so that the land may bring forth her incrcase; and some part at least of the organising energies of the modern community must be brought to bear on problems which have hitherto been left by our urban rulers to take care ol themselves. 


\section{CHAPTER II. \\ THE POVER'TY OF 'THE LABOURER. \\ $\S 1$. W $\mathrm{AGES}$.}

GRICULTURAL labourers are elassed in the offieia returns* under the following four headings, each class being paid on the average a little worse than the last :

Wages and Numbers of Agricultural Labourers in England $\dagger$

\begin{tabular}{|c|c|c|c|}
\hline Class of Labourer. & Wages. & Number. & $\begin{array}{l}\text { Percentage of all } \\
\text { Asriculturists. }\end{array}$ \\
\hline Shepherds... & s. ${ }_{19}$ d. & 25,366 & $2 \cdot 6$ \\
\hline Cattlemen... & 19 & 85,099 & $8 \cdot 4$ \\
\hline Horsemen & 189 & 154,382 & $15 \cdot 6$ \\
\hline Ordinary Labourers & 176 & 356,221 & $36 \cdot 0$ \\
\hline
\end{tabular}

It will be notieed that the worst paid class of labourer is also by far the most numerous. It must also be remembered that these are only average figures. $17 \mathrm{~s}$. $6 \mathrm{~d}$., the average of ordinary labourers for the whole country, is far higher than mańy of the county averages-e.g., 14s. 11d. in Oxfordshire, 15s. 4d. in Norfolk. These figures include allowamces in kind; the cash wages are far lower: 12s. 11d. in Oxfordshire, 12s. 7d. in Norfolk, 12s. 5d. in Suffolk, 12s. 1d. in Dorsetshire.

And these county figures are again averages which reveal the existence of wages in individual cases far below anything mentioned in the returns. For instanee, the late Miss Maud Davies, in her elever book, Life in an English Tillage, gives

* In the Board of 'Trade Fiftcenth Abstract of Labour Statistics, Cd. 6228, 1912, the Board of Trade Report on the Inquiry into Earnings and Hours of Labour (v. Agriculture in 1907), C.d. 5.460, is given as the authority, and may be assumed to contain the latest available statistics.

†Tables of wages in cach county of England and Wales are to be found in Appendix $\mathbf{B}$.

$\ddagger$ Unwin, 1909 . 
between 14s. and $15 \mathrm{~s}$. as the wage in her Wiltshire village, as against the 16s. 9d. given in the official report as the comnty average. Mr. Mann found $14 \mathrm{~s}$. 4 .d. to be the arerage of a typical Bedfordshire village, as against the 17s. 5d. of the oflicial returns.* Mr. George Edwards, of the Agricultural Labourers' Union, has quoted 10s., 11s., and 12s. as the wages paid in Oxfordshire, as against the official 16s. 4 d.

In quoting the official reports it is therefore well to remember that :

(i) They do not inelude easual labourers, though these are stated to number a fifth of the total labour in agriculture.

(ii) They deal only with able-bodied adult men, and cxelude old and infirm men, and also women and young persons.

(iii) 'They are calculated from information supplied by a small and picked minority of employers, under whom conditions of labour are probably most free from reproach. 'The method employed has been to send schedules to farmers who are known to the Department and to the Local Authority; all of these are employers who would have least reason to wish to aroid answering questions about their workpeople. There are in Great Britain some 170,000 holdings over 50 acres in extent, and probably about the same number of large farmers. Yet only 45,000 schedules were sent out in the United Kingdom, and of these only 15,800 replies were receired suitable for use, covering 50,459 labourers in all.

(iv) A large portion of agricultural wages are paid in kind, such as free or eheap cottages, potatoes or potato ground, fuel, beer, or even board and lodging for unmarried men. Special payments, known as Michaelmas money, harvest money, and lamb money, ete., are also made at times of excessive work, amounting in some cases to as much as $\mathfrak{f 5}$ per annum.

In the ease of ordinary labourers these extra carnings and allowances ranged from an average of $7 \mathrm{~s}$. 4.d. in Westmorcland to 1s. 8d. in Middlesex. "'They were greatest in those counties where large numbers of the men were pro-

* Life in an Finglish Village. P. H. M4NN, Sociologieal Papers, 1904. † Cd. 6277. 
vided with board and lodging (e.g., Cumberland, Westmoreland, and Laneashire), and in counties in which extra payments for harvest were high, or much piecework was done (as in Lincolnshire, Suffolk. Hampshire, and Dorsetshire)." In the ease of horsemen, they ranged in 20 counties from 3s. to less than $4 \mathrm{~s}$, and in 16 others from 2s. to less than 3s. "In Wiltshire, Dorsetshire, the East and North Ridings of Yorkshire, and in Lincolnshire the average cash rate of pay did not reach 14s. per week," and "the average total earnings in these distriets was lower than the general average for England as a whole."* For eattlemen the value of extra earnings and allowanees for England, as a whole, averaged 3s., and for shepherds 3s. 8d. The average eash wages for England, as a whole, were: Labourers, 14s. 6d.; horsemen, 15s. 3d. ; eattlemen, 16s. 1d. ; shepherds, 15s. $11 \mathrm{~d}$.

It is therefore diffieult to ealeulate the exact value of the labourers' weekly wage, especially as employers tend to exaggerate the value of the payments in kind. "Further inquiry," sarys Miss Davies, "revealed a strong tendeney amongst some of the employers to estimate the extras given at a rather liberal rate."

\section{$\S 2$. Hours of LABOUR.}

There is no definite official information as to the hours worked by agrieultural labourers. The Board of Trade report quoted above estimates the working day for ordinary labourers as eleven or twelve hours in summer, inelusive of meal times; while in winter it is generally limited by the hours of daylight. Half an hour is usually allowed for breakfast, and an hour for dinner. But the hours of horsemen, cattlemen, and shepherds are admittedly longer than those of the ordinary labourer. Horsemen begin their duties before the rest of the farm is awake, and are often at work when the other hands have gone home to tea. The first milking usually neessitates rising in the very early hours of the morning; and all men in charge of animals, whether horsemen, eattlemen, or shepherds, have to bear a share of necessary Sunday work, for which, very often, no extra wage is paid. Calving 
and lambing entail night work of a partieularly tiring kind, in the course of which at least one labourer, and sometimes more, assists the farmer himself.

When all due allowance has been made for the uncertainty of the duties and the lack of positive information as to the number of hours worked, it is no exaggeration to say that an agricultural labourer may think himself lucky if he earns $3 \frac{1}{2}$ d. an hour, and many do not even earn $3 \mathrm{~d}$. Private inquiries in typical villages of cach county revealed that in those villages the wages amounted to 4 . an hour and over in five counties of England, 3d. an hour or under in 29 different counties, while in Dorset and Somerset cases were actually found of horsemen worling at 2 d. an hour during the summer.*

Holidays, exeept Christmas Day and Good Friday, are unknown in many parts of England and Wales, though the practice of granting Bank Holidays scems to be on the increase. Where men are engaged monthly or half-ycarly, deductions are not as a rule made for short periods of siekness, though sueh deductions are by no means umusual. But where the engagement is weekly many employers pay only for time actually worked. And in the Eastern, Midland, and Southern Counties, where a large proportion of the farming operations are performed on piecework, sickness or wet weather means loss of pay altogether.

What is not generally realised is that in the matter of hours the labourer is far worse off than he used to be. $A n$ eight hours' day for the agricultural labourer was actually the custom in England at the end of the eighteenth century. William Marshall, the agrieulturist, while mentioning that the ploughmen of Norfolk sometimes wrought as long as ten hours a day, says that in most parts of the kingdom eight hours a day was the ordinary custom for team labour +

Indeed, in some eountics the hours were even shorter. In Buekinghamshire, where labourers now work twelve hours in summer, the ploughmen of 120 years ago went out from Candlemas to Martinmas at 7 in the morning, and returned at 3 in the afternoon; and in the winter half-year they went

* See Appendix C.

†Rural Economy of Norfolk, IV. Manshat. (London, 1787), Vol. I. p. 138. 
out at 8 and returned at 3. They had also, of course, to attend to the feeding and cleaning of the horses at home.*

Marshall's Reviewo of Reports to the Board of Agriculture for the Midland Department of England gives particulars of the working time in the various counties. In Bedfordshire it was from 6 to 2 or 7 to 3 in the summer, and from daylight till 1 or 2 in the afternoon in the winter, with an interruption for a meal about 10 called " beaver-time." In Warwickshire it was from 6 to 2 or 7 to 3 in summer, and in winter about 6 hours. In Hampshire the rural labourers seldom reaehed work in winter before $S$ or 9 , or even 9.30 , and left about 3 ; while in summer they would generally be met returning from work about 5 ; the reason given being that they had a great choice of oecupation there, and could not be got to work longer at day work on a farm than other labourers wrought at task work in the forests or at the salt pans, or on the canals, or at the varicty of jobs to be found at Portsmouth.

In agriculture, as in other oecupations, the very long working day seems to have been the gradual fruit of the industrial revolution. But whereas in many other trades there have been reductions of hours which have brought back the working day to what it was three or four hundred years ago, in agrieulture there has been no swing of the pendulum.

\section{§3. Otier family Eariings.}

In estimating the poverty of the labourer and his family it is only fair to take into eonsideration the possibility (1) of the wage-earner adding to his wages by cxtra work outside his regular employment, and (2) of other members of his family adding to his incorne.

These two possibilities-and it will be seen that they are sufficiently remote-do not detract from the folly, amounting to a national seandal, of leaving the workers of the largest single industry of the country sweated and underpaid. But they do mitigate, in a few cases at least, the individual hardships; and no pieture of the agricultural labourer's position is complete until they have been taken into consideration.

* Agriculture of Buchingham, Janes Mancolm (1794), p. 39. 
(i) It is commonly supposed that the agricultural labourer adds considerably to his wages by kceping pigs and poultry and by selling or consuming the produce of his garden. The description already given of the hours worked by the labourer for his employer must be suffieient to convinee the most optimistie that there is not much time left lim to work for himself. Not infrequently he lives some distance from his work; and it is not by any means certain that he has the necessary land. The demand for allotments is strong evidenec of the insufficiency or lack of cottage gardens; and this demand is still unsatisfied in many villages.*

Morcover, allotments are generally only available at some distance from the labourer's cottage, which still further limits his time of working there. Only a minority of labourers possess either pigs or poultry. Any calculation as to the amount labourers actually manage to earn apart from their wages must be largely guess-work; but the best information lends support to the belief that on the average only a few pence a week are added to the wage in this way, and in vast numbers of cases nothing at all.

(ii) With regard to the earnings of the members of the family, the older sons sometimes find work on the farm and contribute from their earnings to the family income. The wages of boys on farms are low, and the tied cottage is often the means of exposing boys to the necessity of accepting wages lower than usual, or even, in well-authenticated cases, of working for nothing at all. $\uparrow$ But the fact that the agri-

* See Appendix D for facts re Allotments.

$\dagger \mathrm{A}$, aged 15 , works for a farmer who estimates his wage at $6 \mathrm{~s}$. per week, but pays him no cash, and says the rottage in which the boy's father (who is a criple) lives is worth fis. The loy fell off a eart, and was away from work 10 days. Rent had to be paid during this period; the fanily was ton frightened to apply for compensation for the boy, who was not insurer.

B, lif $\frac{1}{2}$ years of age, works for a farmer who values bis work at $7 \mathrm{s.,}$ gives him $4 \mathrm{~s}$., and takes $3 \mathrm{~s}$. as rent for cottage in which the father, who is a consunptive, lives. 'The farmer threatens to turn the family out if the boy does not work for lim. 'The mother spent a weck tramping round to try to find another rottage, but could find none. As result of drinking water from a pond adjoining the eottage, there was a case of typlioid (which cost the ratejilyers $\& 40$ for treatment in an isolation hospital), so water is now earried to the cottage from a woll 275 yards distant. 
cultural labourer is often receiving his maximum wage as early as twenty tends to make early marriage popular, and this, combined with the steady emigration of the younger men to the towns, decreases the importance of the help which the family can expect from their sons.

The girls and their mothers, if in the neighbourhood of a town, may both earn something at laundry work, and the girls often go into service in the neighbourhood and send their wages home. But agrieulture affords little opening for women at the present time.*

It may therefore safely be assumed that in the majority of eases the whole of the family ineome eomes from the one wage-earner, who is generally the father. How small that income is has already been shown; how inadequate to the needs of those dependent upon it can only be judged by a consideration of the cost of living.

\section{§4. The Cost of Living in Agricultural Districts.}

The best way of estimating the cost of living will perhaps be the quotation of weekly budgets of agrieultural workers in a state of comparative comfort. Unfortunately such budgets are extremely rare. Few efforts have been made to tabulate definitely the expenditure of rural labourers, and such as have been made have generally been published to illustrate the expenses of the badly paid labourer, and are therefore useless for the present purpose of finding out what the labourer ought to be able to spend rather than what he does spend. 'The best authorities are again Miss M. H. Davies and Mr. Mann. $\dagger$

* Official information fails us on this point, and it is imperative that the Board of Agrieulture should furnish proper statisties concerning the employnent of women. But, aeeording to the Census Reports, female labourers and farm servants numbered in 1851, 148,$475 ; 1861,90,525 ; 1871,58,112$; and women employed in agriculture numbered in $1881,40,346 ; 1891,24,150$. See also HasBacu, The II istory of the Agricultural Labourer, King \& Son, 1908; and the linglishwoman's Yearbook.

† Since writing the above has appeared IIow the Labourer Lives, by B. Sekbonim Rowntref: (Nelson, 1913), which is now the main authority. 
Mr. Mann, with Mr. Rowntree's help, sought to find the minimum standard of cost of food, cost of rent, and cost of elothing and household sundries in the village of Ridymount, 12 miles from Bedford, in the autumn of 1903. As a result he gives the following table:

\begin{tabular}{|c|c|c|c|c|c|c|c|}
\hline \multicolumn{3}{|c|}{ Food. } & \multicolumn{5}{|c|}{ s. d. } \\
\hline Flour & $\ldots$ & $\ldots$ & $\ldots$ & $\ldots$ & 1 & $8 \mathrm{p}$ & er stone. \\
\hline New Milk & $\ldots$ & $\ldots$ & $\ldots$ & $\ldots$ & 0 & $1 \frac{1}{2}$ & er pint. \\
\hline Skim or Sep & arates & Milk & $\ldots$ & $\ldots$ & 0 & $0 \frac{1}{2}$ & \\
\hline Oatmeal & $\ldots$ & $\ldots$ & $\ldots$ & $\ldots$ & 0 & $2 p$ & er lb. \\
\hline Bacon ... & $\ldots$ & $\ldots$ & $\ldots$ & $\ldots$ & 0 & 8 & , \\
\hline Cheese & $\ldots$ & $\ldots$ & $\ldots$ & $\ldots$ & 0 & 7 & , \\
\hline Sugar ... & $\ldots$ & $\ldots$ & $\ldots$ & $\ldots$ & 0 & $1 \frac{1}{2}$ & " \\
\hline Potatoes & $\ldots$ & $\ldots$ & $\ldots$ & $\ldots$ & 0 & $0 \frac{1}{2}$ & „, \\
\hline Margarine, & ard & $\ldots$ & $\ldots$ & $\ldots$ & 0 & 6 & ," \\
\hline Butter & $\ldots$ & $\ldots$ & $\ldots$ & $1 \mathrm{~s}$. to & 1 & 4 & , \\
\hline Biscuits & $\ldots$ & $\ldots$ & $\ldots$ & $\ldots$ & 0 & 4 & ", \\
\hline Cocoa ... & $\ldots$ & $\ldots$ & $\ldots$ & $\ldots$ & 1 & 0 & , \\
\hline Treacle & $\ldots$ & $\ldots$ & $\ldots$ & $\ldots$ & 0 & 3 & ", \\
\hline Onions... & $\ldots$ & $\ldots$ & $\ldots$ & d. to & 0 & 1 & ", \\
\hline Tea $\quad \ldots$ & $\ldots$ & $\ldots$ & $\ldots$ & $\ldots$ & 1 & 4 & , \\
\hline Coffee ... & $\ldots$ & $\ldots$ & $\ldots$ & $\ldots$ & 1 & 0 & ," \\
\hline Currants & $\ldots$ & $\ldots$ & $\ldots$ & $\ldots$ & 0 & $3 \frac{1}{2}$ & \\
\hline Suet $\ldots$ & $\ldots$ & $\ldots$ & $\ldots$ & $\ldots$ & 0 & 6 & , \\
\hline
\end{tabular}

These figures approach so nearly to those given by Rowntree that the autlior decided to adopt his standard of the neeessary minimum cost of food for the maintenance of physieal health :

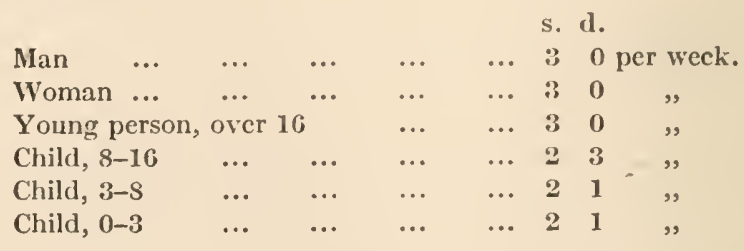

Similar detailed calculations as to the cost of household sundries, due allowance bcing madc for the fact that a certain amount of firewood and fuel eould be pieked up, led to the compilation of the following table, which repre- 
sents Mr. Mann's view of the absolute minimum necessary expenditure per week :

\begin{tabular}{|c|c|c|c|c|c|c|c|}
\hline \multicolumn{2}{|l|}{ Family. } & \multicolumn{2}{|c|}{ Food. } & \multicolumn{2}{|c|}{ Rent. } & $\begin{array}{l}\text { Household } \\
\text { Sundries. }\end{array}$ & Total. \\
\hline 1 Man or 1 woman & ... & & & & & s. d. & $\begin{array}{ll}\text { s. } & \text { d. } \\
5 & 8\end{array}$ \\
\hline 1 man and 1 woman $\because$ & ... & 6 & 0 & 1 & 6 & 24 & 910 \\
\hline $1 \mathrm{man}, 1$ woman, 1 child & ... & 8 & 3 & 1 & 6 & 211 & 128 \\
\hline 1 man, I woman, 2 children & .. & 10 & 6 & 1 & 6 & 36 & 15 \\
\hline 1 man, 1 woman, 3 cliildren. & ... & 12 & 9 & 1 & 6 & 41 & 184 \\
\hline 1 man, 1 woman, 4 children . & $\ldots$ & 15 & 0 & 1 & 6 & 48 & 212 \\
\hline 1 man, 1 woman, 5 children. & $\ldots$ & 17 & 3 & 1 & 6 & 53 & 240 \\
\hline 1 man, 1 woman, 6 children . & $\cdots$ & 19 & 6 & 1 & 6 & 510 & 2610 \\
\hline 1 man, 1 woman, 7 children. & ... & 21 & 9 & 2 & 0 & 65 & 302 \\
\hline 1 man, 1 woman, 8 ehildren. & ... & 24 & 0 & 2 & 0 & 70 & 330 \\
\hline
\end{tabular}

In York 21s. 8d. was considered by Rowntree to be sufficient for man, wife, and three children. In the ease of the agricultural labourer, rent and the cost of fuel are lower.

Miss Davies gives the following figures as the very lowest on which efficiency is possible:

$\begin{array}{lll}\text { Food } & \ldots & \text { 3s. per adult, and 2s. 3d. per child. } \\ \text { Rent } & \ldots & \text { Saved from proceeds of garden.* } \\ \text { Firing } & \ldots & \text { Is. per houseliold. } \\ \text { Sundries } & \ldots & \text { 2d. per liead. } \\ \text { Dress } & \ldots & \text { Adult } 6 \text { d., and clild } 3 \mathrm{~d} .\end{array}$

From these figures the following table is compiled :

\begin{tabular}{|c|c|c|c|}
\hline & Food. & $\begin{array}{l}\text { Dress, Sun- } \\
\text { dries, etc. }\end{array}$ & Total. \\
\hline Amount required for 2 adults and 2 & s. d. & s. d. & s. d. \\
\hline $\begin{array}{cccc}\text { children... } & \ldots & \ldots & \ldots\end{array}$ & 306 & $\therefore 6$ & 140 \\
\hline $\begin{array}{c}\text { Amount required for } 2 \text { adults and } 3 \\
\text { children... } \ldots\end{array}$ & 129 & & \\
\hline $\begin{array}{c}\text { Amount required for } 2 \text { adults and } 4 \\
\text { children... } \ldots\end{array}$ & 150 & & 198 \\
\hline $\begin{array}{c}\text { Amount required for } 2 \text { adulls and } 5 \\
\text { children... } \quad \ldots \\
\text {... }\end{array}$ & 173 & j 3 & \\
\hline
\end{tabular}

* But see par. \$: (i) above 
These groups probably include most families of an average size, and the amounts given probably represent with comparative accuracy the amount required for the maintenance of a labourer's family. In addition, the following more detailed budget may be compiled from statistics connected with the fiseal controversy, and published with additional information as an appendix to Cd. 2376 of 1905 :

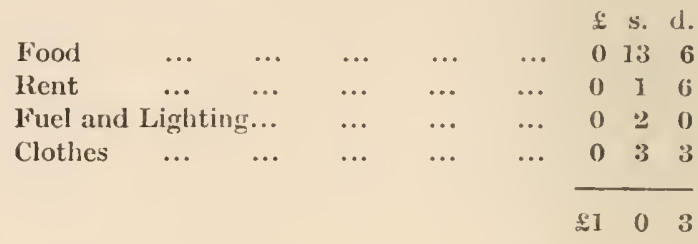

In these estimates no allowance is made for smaller household requirements, beer, tobacco, amusements, or eren the inevitable Sunday paper. 'The amount spent on beer and tobaceo will obviously depend upon the character of the individual family. Two shillings, however, may be added to give an approximate anount for this expenditure, and fourpence for insurance, and the total then becomes $22 \mathrm{~s}$. $7 \mathrm{dl}$. It may, therefore, be acepted that a labourer with a wage of under $22 \mathrm{~s}$. 7 d. a week, ten years ago, was not receiving sufficient to maintain a reasonable standard of comfort, and that one with less than 20s. 4 d. per week, with a family of a verage size, was unable to obtain the barest necessities of life. And the cost of living has inereased in the last ten years. But cven if we take this pound a week standard as being the living wage when there is only one wage-earner in the family, and where his wages are the only form of ineome, a reference to the tables quoted in the Appendix will show that the wages of ordinary agricultural labourers are several shillings below this level in every area outside the Northern Counties, and that the earnings of the men in charge of animals are considerably less over most of the Southern and Eastern Counties not in close proximity to London.

It must be remembered, too, that the agricultural labourer has been more hardly hit by the decrease in the purchasing power of his wage than almost anyone else. 
'This decrease has been estinlated by Mr. Chiozza Money at 20 per cent. from 1895 to 1911 . In the first place, this affects the agricultural labourer espeeially, because, as he is not in receipt of a living wage, it all eomes out of the bare neeessities of life in his case. And, in the seeond plaee, he las not shared to the same extent in the counterbalancing rise of wages during that period. 'The rate of wage of the workers generally has risen $12 \frac{1}{2}$ per eent. sinee 1895 , while the rate of agricultural wages has only risen 9.6 per cent. The Board of Trade Report above quoted gives the following tables :

Average Weekly farnings of the "Selected Class" of Agricultural Labourers.

\begin{tabular}{|c|c|c|c|c|c|c|c|}
\hline \multirow{2}{*}{\multicolumn{2}{|c|}{ Country. }} & & \multirow[b]{2}{*}{1907.} & \multirow[b]{2}{*}{1902.} & \multirow[b]{2}{*}{ 1893. } & \multicolumn{2}{|c|}{$\begin{array}{l}\text { Increase in } 1907 \text { as } \\
\text { compared with }\end{array}$} \\
\hline & & & & & & 1902. & 1898. \\
\hline $\begin{array}{l}\text { England } \\
\text { Scotland }\end{array}$ & $\cdots$ & $\cdots$ & $\begin{array}{rr}\text { s. } & \text { d. } \\
17 & 7 \\
19 & 7\end{array}$ & $\begin{array}{rc}\text { s. } & \text { d. } \\
17 & 5 \\
19 & 5\end{array}$ & $\begin{array}{rr}\text { s. } & \text { d. } \\
16 & 9 \\
18 & 2\end{array}$ & $\begin{array}{ll}\text { s. } & \text { d. } \\
0 & 2 \\
0 & 2\end{array}$ & $\begin{array}{cr}\text { s. } & \text { d. } \\
0 & 10 \\
1 & 5\end{array}$ \\
\hline
\end{tabular}

\begin{tabular}{|c|c|c|c|c|c|c|}
\hline Country. & 1830. & 1390. & 1900. & 1907. & 1908. & 1909. \\
\hline $\begin{array}{c}\text { *Enrland and Wales (156 } \\
\text { farms) } \ldots \\
\text { Scotland (98 farms) } \ldots\end{array}$ & $\begin{array}{l}92 \cdot 6 \\
89 \cdot 5\end{array}$ & $\begin{array}{l}91 \cdot 4 \\
93 \cdot 3\end{array}$ & $\begin{array}{l}100 \cdot 0 \\
100 \cdot 0\end{array}$ & $\begin{array}{l}102 \cdot 0 \\
104 \cdot 3\end{array}$ & \begin{tabular}{|l|}
$102 \cdot 4$ \\
$101 \cdot 9$
\end{tabular} & $\begin{array}{l}102 \cdot 6 \\
102 \cdot 8\end{array}$ \\
\hline
\end{tabular}

\section{§ 5. The Cottage Question.}

In the estimates of the cost of living above quoted, rent is given as 1s. or 1s. 6d. per week. This is based on the Board of Trade Report of 1905, which gave partieulars as to the highest rents, lowest rents, and usual rents in the distriets where the inquiries were made. The usual rent given raried from $1 \mathrm{~s}$. to $2 \mathrm{~s}$., and $1 \mathrm{~s}$. $6 \mathrm{~d}$. was the most usual

* Index Numbers based on Cash Wages only. 
figure, the landlords generally doing repairs and paying taxes.*

On pagc 44 of Chapter VII. Mr. W. C. Little, Senior Assistant Commissioner to the Royal Commission on Labour, reviewing the statements of the other Commissioners who had reported on typical agricultural districts in nearly every county in England, is shown as saying that the estimates of Assistant Commissioners and their informants as to the value of a cottage and a garden varied from $£ 210$ s. to $£ 54$ s. a year, the most usual sum being $£ 4$. Mr. Little further said: "Rent has generally no relation to the size of the cottage and cost of its construction, the accommodation it affords, the conditions as regards repair and sanitary arrangements, or to the earnings of the occupier."

A rent of 1 s. or $1 \mathrm{~s}$. $6 \mathrm{~d}$. is low compared with the rents paid in urban districts. But this does not mean that the rural labourer is really better off in this respect. For, in the first place, the cottages often belong to the employers, who charge a low rent instead of paying a decent wage ; and,

* See, on the other hand, the following table given in the Housing IIandbook Up to Date, by Alderuan Thompson (p. 175), King \& Son, 1910 :

Number of Rooms and Weekly Rent.

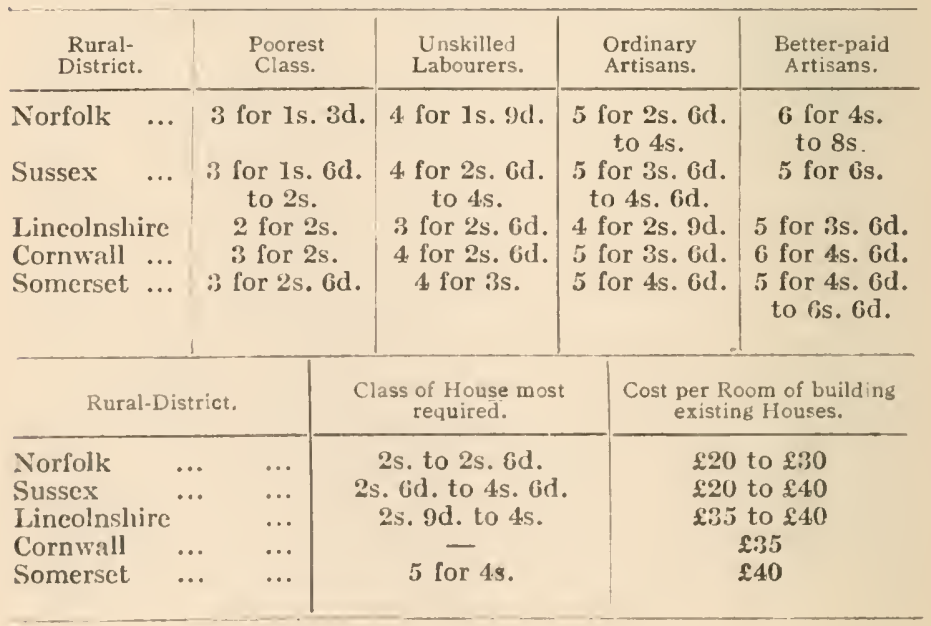


secondly, many of the cottages are often uninhabitable, being old, in bad repair, and far too small for the average family; thirdly, the dearth of cottages is so marked a feature of village life that most labourers have no choiee of a dwclling, but are compelled to put up with anything they can get.

Overcrowding is as prevalent in the country districts of to-day as in the worst slums of our towns. The Select Committee above referred to reported in 1906 that the Housing Acts had always been a dead letter in country districts, and that while in the towns, where public opinion is more acute, the Acts have been in comparison more uniformly administered, the authorities entrusted with their administration "in rural distriets have, generally speaking, deplorably failed in their obligations." Private inquiries* amply bear out the reports of County Medical Officers of Health and the evidence so abundantly brought before Public Committees of Inquiry.t The Medical Officer of Health for Bedfordshire reported of Biggleswade: "One frequently finds a bedroom is occupied by three or four adult members of the same family of both sexes." In Billericay, in Essex, an inquiry by the Medical Officer revealed 44 cases of overcrowding, and, speaking of this county as a whole, he reported "that there is a general want of cottages with three bedrooms, and, in consequence of this, overcrowding from time to time occurs, immorality is fostered, and diseases spread." He also complained that "there are no better houses into which the tenants can remove." This complaint is repeated ad nauseam in the Medical Reports. "The oecupier has been giren notice to quit, but there is nowhere for him to go." $\ddagger$ "MIany cases of overerowding were observed, and considerable diffieulty

* An investigator reports the following case on the Dorset coast. A damp old house with 2 small, ill-ventilated bedrooms, a draughty small kitchen, and an out-scullery, inlıbited by an old father and mother, a grown-up son and his wife and her illegitimate child, a widowed daughter with 4 young children, a very young unmarried girl and her illegitimate child, making 12 persons in all. No vacant rooms are to be had anywhere in the neighbourhood.

$\dagger$ See also Our I'illage IIomes, by Hugu Aronsos, 1913; and The Collage Homes of England, by W. Walter Crotch, 1908. ¥ Crowland, Lineolnshire. 
was experienced in dealing with this condition owing to the faet that there was usually no ehoiee of other and more commodious residenee to the families coneerned." * "If a house is condemned, there is no other for the people to go to." $\dagger$

The lack of cottages, as many Poor Law Guardians know, is sometimes the eause of families eoming to the workhouse. In one ease a man threw up his employment for this reason, and an inquiry by the Guardians proved that in the whole Union of some 40 villages there was not a single eottage available. In the next Union a similar ease oecurred. The Wroxham ease, in which, owing to a ehange of landlord, several tenants were given notiee to quit, brought this aspeet of the matter prominently before the public in Norfolk some time ago. There were no houses anywhere, and some 40 persons were temporarily provided for, partly by their neighbours and partly in boat-houses, until an old railway earriage was purehased by public subscription, where most of them lived, huddled together, for nine months, until the loeal member of Parliament had built six new eottages, in default of any other solution of the question.

But what need is there of further witness? The Select Committee reported in the following terms :

"The Committee have had abundant evidence before them as to the insufficieney of cottages in rural districts. Cases have been brought to their notice in which people have had to leave a village because of their lack of house accommodation, while others have been prevented from eoming to live in a district because no louse or eottage was to be found fit to live in, and there was no one financially interested in meeting the demand by building. The house famine in town and eountry which often exists in regard to the working classes is incontestable. The many investigations, Royal Commissions on Housing and Labour, ete., Seleet Committees of the House of Commons, and offieial departmental reports have placed the fact beyond eontroversy."

* Grantham.

$\dagger$ Oundle, Northamptonshire. 
Alderman Thompson, of the National Housing Council, calculated the shortage of cottages at 100,000 , and this is a generally aceepted estimate. But it was made some years ago, and the situation is yearly getting worse owing to the working of the Housing Acts.*

It is not only that cottages are lacking, but those that exist are as a rule too small. It was given in evidence before the Select Committee on Housing that of 124,763 houses in the rural districts of Northumberland 118,907 had less than five rooms. An inquiry made in 17 different counties showed that in 44 villages there were 464 cottages with only one bedroom, and 1,852 with only two, and in many cases what was called a seeond bedroom was really a landing.

The County Medical Offiecr for IIcrts reported of one village that there was no cottage with more than two bedrooms, and in one case they were slept in by two parents and eight children. Dr. Armistead inspected 365 houses in the Linton Rural District in 1911, and found that 77 per cent. of the houses had not got three bedrooms; 57 of them had only onc. There ean be no doubt at all on the evidence that the majority of cottages in the country have only one or two bedrooms; they are in thousands of eases oceupicd by families of from 6 to 10 persons, and sometimes by more than one family. But even apart from these cases it is obvious that the average cottage is overcroveded if inhabited by the average family.

The insanitary and, indeed, deplorable condition of cottage property is again amply proved by Medical Officers' reports throughout the country, $\dagger$ and by reports of inquiries held under the Housing Acts (1890-1909). Houses with no fireplaces, with no water supply, with no sinks and no privies are quite common in our villages. The slop water is thrown in the road, and the eloset is shared with other cottages. The walls are damp, the floors are laid directly on the earth and are rotten with moisture, the roofs let in the rain. And these things exist not in exceptional localities,

* See below p. 37, footnote.

$\dagger$ Report of the Select Committee, 1906, 376. 
but practieally all over the country.* In one case a man gave evidence before a Housing Inquiry that he had to move his bed from side to side whenever it rained. Another spoke of putting up an umbrella to keep off the rain in bed at night. And at the same inquiry, where every kind of abuse had been proved up to the hilt, the Sanitary Inspector declared that he knew villages where the conditions were worse, and the Local Authorities gave this as their reason for refusing to act. $\dagger$

An inquiry made in 1897 , extending over 4,179 cottages in 78 villages, revealed that 25 per cent. were bad or extremely bad, 60 per cent. had no fireplaces in any bedroom, 15 per cent. no water supply or a very bad one.

Another inquiry, extending over 240 villages of about 10,000 cottages, revealed the fact that about one-half were "bad."

On this aspect of the subject the report of the Select Committee is quite definite.

"More than one witness has urged by way of excuse on behalf of the Medical Officers and their Councils that the reluctance to condemn insanitary property was due to the fact that sufficient accommodation was not available, that the procedure was complicated, that it would only accentuate the evil, and that building by the Council was out of the question because of the loss that would be incurred. The only alternative that appeared to present itself was either to render the inmates homcless or to allow them to live in the surroundings responsible for much misery.

"This contention, however, loses its force in view of the absence of any cffort at adequate inspection. Nuisances may be suppressed and defects made good as they oecur without any question of demolition arising at all. If Medical Officers and Inspectors of Nuisances hâd earried out

* "When the owners of village slum property find it a profitable investment there is a strong disinclination to attract attention to the need for more or better cottages, as in the event of these being provided the bad cottages would become unoceupied. On many Rural District Councils members may be found who are interested in property of this kind " (Report of the Select Committee of the Housing of the Working Classes Acts Amendment Bill, 1906, 376).

+ Aronson, p. 22. 
the existing law in bringing the facts before the owners from time to time by notices and summonses, much could have been done to prevent houses getting into a state of disrepair. By strict supervision houses gradually falling into an insanitary condition might at slight cost be made habitable in the early stages. This in turn would pay the owners of the property, because repairs carried out regularly can be done at small cost, whereas neglect entails considerable outlay at the best, and the demolition order at the worst. Whatever difficulties there may be in the way of building new cottages, keeping the existing ones in reasonable repair under the existing law, so as not to be a nuisance or injurious to health, is practicable, and ought to be insisted upon."

But however great the need of inspection may be, it is obvious that the real need is more cottages. People do not live like pigs because they want to ; they would not put up with insanitary cottages if they had any possible alternative. There was a row of cottages in Buckinghamshire known as Hell Corner, whose inhabitants were living in a most degraded condition. A neighbouring landowner bought them up a few years ago as an experiment, and rehoused the same people in new, clean, and roomy dwellings, and in every case, with one exception, the new cottages are a model of cleanliness, and the tenants are perfectly satisfactory. There can be no doubt that had such cottages been available before, the families would have gladly moved into them. It is the dearth of cottages that is responsible for the faet that dirty, overcrowded, and insanitary dwellings are inhabited at all.

The same dearth is the direct cause of the tyranny of the tied cottage system, which has already been mentioned in connection with lay labour. This tyranny is well known, but it is sometimes misunderstood. The eases of political persecution which come into prominence in the daily Press ocensionally are really of small importance beside the constant pressure that is brought to bear on men to live in unhealthy places, drink unwholesome water, and work for wages even smaller than usual, simply by the lact that the cottage in which they live belongs to their employer, and they have nowhere else to go.

A good deal of public odium is attached to the employer 
in this connection, but it must not be forgotten that he is not the only instance of a property owner taking advantage of the dearth of cottages to exploit the tenant. The village publican who owns property will sometimes compel his tenants to come regularly to his house; the village buteher will palm off upon them meat that he eould not otherwise casily get rid of; no complaint can be made by the tenants, or out they go. If there were nore cottages, these things could not be, and the village labourer would be a freer man. The lack of cottagcs is at the root of all the petty tyrannies of village life. It is the most terrible symptom of the poverty of the agrieultural labourer, who cannot afford to pay out of his pitiful wage a rent large enough to make the building of new cottages a commcrcial undertaking. And so a whole generation of young country folk are caught up in the vieions circle which breeds out of present-day poverty further poverty and degeneration in the future. Born of fathers who are sweated and underpaid, whose hours of work are too long, to whom no chance of advancement has ever come, who are directly under the hecl of others, and who are the victims, more than any other portion of the community, of petty tyranny and social wrong, the children of the countryside not only lack food and milk and the barest necessaries of life, but are poisoned in the fetid air of erowded rooms, and are grudged the room to live.*

* See Appendix $\mathrm{E}$ for deseription of a typieal village in the West of England by an investigator. 


\section{CHAPTER III.}

\section{A MINIMUM IVAGE FOR AGRICULTURE.}

\section{\$ 1. Tine Case for Legislation.}

7 HE state of things just described points to the neeessity that agricultural wages must be raised. On this at least all students of the rural problem are agreed; difference only arises over the method to be pursued in order to raise them.

Various round-about ways have been suggested. Tariff Reform and Land Taxation have both been urged, largely on the ground that they would raise wages; while others, and perhaps sounder thinkers, look either to the State Development of Agrieulture or to the formation of Trade Unions among the labourers themselves as the surer way. But these things do not " raise" wages; all that even their advocates can claim is that they will lead to changes which will cause wages to rise. Economic predictions of this kind are at best slow and capricious, and when half the economists deny them they must be confessed to be uneertain.

There is a more direet and immediate method. If you want a thing done, just do it. If the nation wants higher wages for agricultural labourers, let it make a law to say so, and establish a legal minimum wage. Let those who doubt the practicability of this consider the numerous examples of minimum wage laws already existing.*

It cannot, of course, be gainsaid that a minimum wage law for agrieulture would be very different from a similar law, say, for the mining industry in this respeet: that in the latter case the wages of a few were levelled up, but the total wage bill was not materially inereased, whereas in the ease of agrieulture the wages of the great majority 
of labourers would be levelled up, and an enormous inerease in the total eost of agrieultural labour must inevitably result.

On the other hand, such an inerease can quite well be borne. If fair wages can be paid in eertain parts of the North of England, they eould be paid in the Midlands or in the South. Take the ease of Cumberland. In the west of that county we find 22s. and 23s. a week being paid, with no reduetion for wet weather and for the shorter hours of winter. Five or six weeks' full pay is commonly allowed for sickness, and no distinction of wage is made between the different elasses of labourers. The main reason for this is that close at hand there is employment to be had in the towns at $30 \mathrm{~s}$. to $40 \mathrm{~s}$. a week, and shorter hours withal. The competition of great industrial centres prevents the rural employer outside from sweating his men. What the natural law of competition ean do for the North a minimum wage law could equally well do for the South.

It may be argued that in the North, and in other places where wages are high, it will be found that the very industrial centres which cause the competition for labour provide also the markets which enable agrieulture to stand the strain of the ligher wage. There is an element of truth in this, and it cannot be too strongly urged that, if agriculture is to be revived, there must be a more systematic marketing of the produce, on lines to be reeommended in a later chapter. But, on the whole, the priec of agricultural produee is fixed not by local but by world eonditions. If that price admits of high wages in Cumberland or in Seotland, it will admit of them in Oxfordshire and Dorsetshire.

Another objection to a minimum wage law will come from those who look for reform not to artifieial statutory regulation from outside, but to the spontaneous proeess of organisation among labourers themselves. There have been many attempts to form Trade Unions in the eounty districts, but up to the present they have met with seant suceess. The backward eonditions of life and thought in the villages, the isolation of the labourers, and the tyranny of the tied-cottage system have combined to prevent the industrial movement from bearing fruit in the country. 
No doubt at the present moment there are signs of an awakening; and even if left to themselves, the men who till the fields will not be long in claiming a fairer reward for their labour. But one of the strongest arguments for a minimum wage law is that it will stimulate that movement. Such a law would eall into cxistenee, in every district, a board on which the workers would be direetly represented. It is impossible to orerestimate the far-reaching effect of this upon the agricultural labourers as a elass. If they have remained unorganised hitherto, it is because it has been found impossible to organise them under existing conditions, but the requirements of a Minimum Wage Act will provide just the neessary stimulus, and eannot fail to result in bringing them speedily into line with other sections of the industrial movement.

There are certain diffieulties in applying the prineiple of the minimum wage to agriculture, of which the true solution must be found.

The first point to decide is whether there should be one uniform national rate applying over the whole country; or whether the minimum should be different for different districts. It is inost important to have a uniform national rate, for the following reasons :

(1) If backward distriets are allowed to remain backward, the object of the minimum wage would be largely defeated at the outset.

(2) The cost of living in rural districts does not vary much all over the country, the chief variation being in the cost of rent.

(3) Differences within a county area would often be as great as differenees over the whole country. It is as easy to surmount the one diffieulty as the others.

(4) By a uniform national rate the constant difficulties that would arise on the margins of areas would be avoided. A farmer in Hertfordshire would rightly resent being compelled to pay a higher wage than his competitor in the same markets across the Buckinghamshire border.

A similar point to be decided is whether to have the same rate for all grades of workers, or to have a separate minimum for horsemen, eattlemen, and shepherds. In some districts 
where the wages are higher, as in the case of West Cumberland quoted above, there is no difference made between the different grades of workers. Moreover, the higher wages of horsemen and cattlemen frequently work out at a smaller rate per hour even than those of the general lahourer, in view of the longer hours of work. In any case, it would seem to be no part of the business of a national minimum wage law to emphasise such dilferences as exist, and the object of the law would be aehieved if there were only one general rate, applicable to all grades of workers, and raising the whole level of wages from below.

In view of the wide discrepancies that exist between the wages paid in different parts of the country, it has been suggested by those who have some expcrience of the working of Wages Boards that in the case of Agriculture the minimum fixed should not really be a minimum at all, but rather a mean figure, a sort of standard set up for the various localities to aim at. The argument appears to be that if a high minimum were fixed, it would be impossible of enforcement, whereas a low minimum would have a demoralising effect in those parts of the country where good wages are already paid. But any such juggling would, like a series of local rates, be running away from the problem. A minimum must be a minimum--it must be fairly high, and it must be enforeed all over the country, the only modification possible being to allow in certain backward districts a short period of time to elapse before it comes into force.

\section{§ 2. Tue Machinery.}

The most important question in connection with the minimum wage law for agriculture is the machinery by which it is to be administered. There is no need to discuss this in great detail here; it will be sufficient to sketch it in outline. The machine must include a National Board to deal with main principles, which are the same all over the country, and Local Boards to apply those principles to the circumstances of the various localities. Both the National Board and the Local Boards should properly consist of direetly elected representatives of both the employers and the employed. In 
the case of Local Boards there should be no diffieulty about this. There would be presumably a Loeal Board for each county area, and periodical elcetions would take plaee in each village, in whieh the labourers would not fail to take considerable interest, seeing that their poekets would be so direetly affeeted. Their class eonseiousness would thus be awakened, and the bonds of old servility and terrorism would be gradually east off. But this eould not happen all at onee, and in many districts intimidation would still be a very real thing for some years. But Wages Boards have proved a boon in trades less favourable to freedom and representation than agrieulture, and deviees, such as voting by sides and not by heads, ${ }^{*}$ have been adopted to counteract intimidation.

In view of this danger, however, it is very doubtful whether it would be safe to leave to the ehances of direet eleetion such important matters as the national rate and eurrent eonditions, which the National Board would have to decide. The first National Board must therefore be formed in some other way, either by representatives from the Local Boards or by nomination. Experience proves that bodies eomposed of representatives of representative bodies are always ineompetent. It will probably be best therefore to have a nominated National Board to start with. And this being so, why should not the national rate, for the first five years at least, be definitely fixed by Parliament itself putting figures in a Bill? The House of Commons, with all its defects, is not likely to be behind publie opinion in a matter of this kind, and is at least as eompetent to judge of the cost of living of the agrieultural labourer as any other body it could appoint.

The course here reeommended would appear a reversal of the decision taken by the House of Commons on the Coal Mines Act. But a eareful perusal of the speeches made on that oeeasion will show that none of the arguments against naming figures in that Bill apply with equal foree to agriculture. Moreover, in the ease of the coal mines, and also of the "sweated trades," the Boards are primarily interested in fixing wages to the satisfaction of those immediately

* In the case of the tailors. 
concerned, and are dealing with eireumstances peculiar to the particular industry. But in the case of agriculture the livelihood of hundreds of thousands of workers all over the country is coneerned, the cireumstanees are, or should be, of common knowledge, and the interests of urban workers are dircetly involved, seeing that the low wages paid in country districts tend to provide the towns with a constant influx of cheap labour.

As to details, the rate should be fixed for a whole week, to be paid, wet or fine, with a provision that if the man works more than, say, fifty hours, more must be paid. Both piece rate and time rate per hour must be relatively high, and if the piece rate were higher than the time rate, it would tend to avoid loss by bad weather. Eventually all payment in kind in lieu of eash wages should be abolished. But until this is done (and it would interfere seriously with local customs) part of the business of the Loeal Boards should be to work out the values of payments in kind, and to seeure that they are suffieient to raise the wage in every individual ease above the minimum. The Local Boards would also have to regulate, in their districts, the amount and kind of work which could be performed by young or old persons, who would be exempted from the provisions of the Aet, within eertain limits laid down by the National Board.*

Evasion of the Act would be made a criminal offence, and workers would be eneouraged to send information to the Boards of any such evasion. The Board would then make its own inquiries, and no one need know from whom the information came.

In order to meet the peculiar cireumstanees of agriculture and avoid the breakdown of the scheme by reason of the intimidation of the labourers and their lack of cohesion, the suggestion has been made to abandon the system of Wages Boards altogether, and administer the Act through the County Councils. No one who knows the composition of the

* In the case of old men, not worth the minimum wage, but able to do a little work, a State pension supplementing the lesser wage might he paid, leading up to the full old age pension later. 'The Loeal Board would liave to provide safeguards to ensure that this was not used by employers to enable them to evade the Act 
average County Couneil would consider the interests of the labourer safe in its hands. It has also been suggested that the wage might be fixed, as rents are fixed in Ireland, by an independent tribunal of a legal character. But this would omit one of the most important features of the scheme. It cannot be too strongly urged that the periodieal eleetion by the men of their own representatives on the Local Boards is fraught with the greatest promise for the organisation and independence of the agricultural labourers of the future.

\section{§3. The Amount of the Wage.}

It now only remains to discuss how much the minimum wage should be. 'The whole question of the minimum wage in any industry involves important issues of political theory. Should the wages be calculated to cover only the barest neeessities of life? What are necessities? Is the wage to be on a family basis? If so, low large may the family be assumed to be ? The average family of three children is really little more frequent than the family of four, five, or six. Are women to receive permanently lower wages than men? There are good reasons for believing that the ultimate solution of these diffieulties in modern countries will be found in the direction of fixing generous wages for adults on an individual basis only, and looking to some other form of provision for the children, as for other non-working sections of the community, the aged and the siek. Indeed such provision is already being made in certain States of America. But as things now are in England, the family of the agricultural labourer depends for existenee on the wage of the father, and the task of the moment is to raise those wages suffieiently to provide at any rate the minimum of civilised life for a family of the arerage size.

A reference to the tables given in the last chapter will prove conelusively that this cannot be clone at present prices under 21s. a week, eren calculating rent at the low figure of Is. But the present overcrowding will not disappear until the dearth of cottage aceommodation is remored by the provision of new cottages. It will be shown in the next chapter that if the new cottages are to be provicled at economic rents, the rent 
of cottage property will rise to 5s., which would necessitate a wage of at least $25 \mathrm{~s}$. a week for their inmates. In view of the difficulty of raising wages to this figure immediately, a scheme of state-aided cottage building is foreshadowed by whieh rents would not exceed 3s. a week, and if this scheme were adopted, a minimum wage of $23 \mathrm{~s}$. a week would meet the immediate needs of the case. To discourage casual labour, the wages should be $25 \mathrm{~s}$. a week if the engagement is for less than a year, and 5s. a day if the engagement is for lcss than a weck. The week should be limited to fifty hours, and overtime should be paid at a higher rate.

This reform is pressing, and is immediatcly practicable; the only modifieation being, as already suggested, that backward districts might, if the Local Wages Board thought fit, apply for a short extension of the period before the law was enforced in their district. In the interim the Local Board would, of course, arrange for a local minimum at a reduced rate.

\section{\$4. The Emect on the Farmer.}

In the long run it would prove true in agriculture, as in every other industry, that better pay means better work. The best authorities admit that in agricultural distriets wherc a fair wage is now paid the work done is proportionately better, and the higher wage throws no extra expense on the employer. Mr. Christopher T'urnor, for cxample, has given it as his opinion that the better-paid labour on his estate in Lincolnshire is less expensive than the far worse paid work of the labourers of Oxfordshire and Dorsetshire. But, however truc this may be, the same result eannot be expected to obtain immediately if wages are raised by Act ol Parliament. The process of improving the value of the work done to the same extent as the incrcased wage might takc a generation, while the incrensed cost of labour would immediatcly fall on the farmer.

It is difficult to estimate with any degree of certainty what that increased cost would be. In any given ease it depends on three factors-the wage at present paid, the kind of farming, and the number of acres per labourer on 
the farm. Thus it would vary not only from distriet to district, but actually from farm to farm.*

But be the inerease great or small, it is quite obviously a burden that the tenant farmer eannot afford, and should not be ealled upon to pay. This leads us to the conclusion that any Minimum Wage Law for Agriculture must contain a clause giving the tenant the right at any time within 12 months of the appointed day to give notice (say, 3 months' notice) to terminate the tenaney at the next quarter day. He will thus have an opportunity of transferring the burden on to shoulders that ean, and ought to, bear it. If he is already rented nearly as heavily as he can bear, $\uparrow$ this will ensure that the bulk of that burden is transferred, while the competition of others anxious for aceess to the land will secure that not more would be transferred than the actual cost of the inereased wage.

In eases where the land is at present let at a lower rent than the landlord could now obtain, or is in the occupation of a tenant whom the landlord dislikes, the effect of bringing the contract automatically to an end would be to enable the landlord to make a better bargain, or to get rid of his tenant sooner than he otherwise could. This is not a serious objection, as leases of farms are usually short, and

* The rate of wages now being paid in any district can be gauged roughly by reference to Appendix B. But the number of acres per labourer is not so easy to ascertain. An attempt is made, for what it is worth, to work out the county averages in Appendix G.

This calculation has at least a negative value, as proving that average figures are valueless, and that, even if extreme cases are left out of account, the number of acres per labourer varies so enormously that it is impossible to arrive at any general conclusion as to the increased cost of farming per acre which a minimum wage law would entail. In Durham, where the average wage is $22 \mathrm{~s} .9 \mathrm{~d}$., and the average number of acres per labourer appears to be $76^{\circ} 4$, a minimum wage of $23 \mathrm{~s}$. would only make a difference of $2 \mathrm{~d}$. per acre per year. Whercas in Suffolk, where the average wage is $16 \mathrm{~s} .7 \mathrm{~d}$., and there are only $26 \cdot 2$ acres per labourer, the avcrage increased cost of labour would be about $8 \mathrm{~s} .4 \mathrm{~d}$. per acre per annum.

† In spite of the large increasc in agricultural values during the last few years therc are considerablc numbers of old tenants whose rents have not been raised, on the principle, held by many landlords, that rent should not be raised on al sitting tenant, even wherc cconomic conditions justify. But the number of occupied farm houses is greater now than it lias ever been before, and when a tenant leaves there is usually competition for the farm. 
the risk to the tenant would be correspondingly small. But it can be practically met by bringing the lease to an end at the option of the tenant only, and, the clause being entirely for his benefit, thcre would be no injustice in leaving it to his option to enforee it.

This opportunity might, of course, be taken for the establishment of fair rent courts, such as have worked well in Ireland. But there are strong reasons against such a course.* Should fair rent courts be established for other reasons, the cost of the minimum wage might, and indeed would, be one of the factors to be taken into consideration. But there is a danger that, if the minimum wage law were connected in the minds of the farmers with any cumbersome legal process, this would be an additional source of unpopularity, with no corresponding benefit to any of the parties concerned. The farmer would be best able to calculate what the minimum wage law would cost him, and he would not require, and would very probably resent, the intrusion of third parties in the matter. Without rent courts the vast majority of eases would be easily and amicably settled. Both landlord and tenant would want to agree, because the one does not want to lose a tenant, nor the other to leave his farm. But if there are possibilities of litigation, the chances of settlement would be diminished.

\section{\$5. The Effect on the Landoond.}

It is nearly as clifficult to average the extent of the burden which would thus be borne by the landlords as it is to average the cost of the minimum wage to the employers of farm labour.

The rents of farms vary cnormously, and there is no official information available. $\dagger$ Where the rent amounts to $50 \mathrm{~s}$. or $60 \mathrm{~s}$. an aere, to transfer the cost of a minimum wage of 23s. would not often reduee the rent by more than 10 per eent., and frequently by 5 per cent. or less. But there are eases where rents are low, down even to 10 s. and 15s. an acre-these occur more frequently in districts where wages are also low, and the extra cost of the minimum

* Sec Report of Royal Commission on Agricultural Depression, 1897, pp. 103-117.

$\dagger$ See Appendix $\mathrm{H}$. 
wage would be correspondingly great. It might well happen that in such instanees the transfer would absorb 50 per eent. of the rent at present paid to the landlord.

This at least it is safe to say. Assuming the average number of aeres per labourer to be 50, and the average wage per labourer 18s. 4d. in England, then the average effect of a wage of 23 s. would be to add about $4 \mathrm{~s}$. 9d. per annum per acre to the cost of farming. Assuming again that the tenant can transfer the whole of this on to the landlord, and that the average rent per acre is at present $£ 1$ (as to which it is impossible to say, but $£ 1$ an aere is the figure that farmers themselves often quote as an arerage), then the minimum wage law would take about 24 per eent. from the rent of the average landlord. This $2 \%$ per cent. is, of course, the mean of eases where the burden would be far less or far more-less where the labourer is already fairly decently paid, more only when the landlord is receiving the existing rent at the price of the labourer's squalor and semi-starvation.

Proposals to "tax the landlord" are open to several objections, such, for instanee, as that they spring from political hatred of this particular class, that they would act as a relief to the industrial capitalist at the landowner's expense, that they would confer no benefit on the countryside, but actually eripple agriculture, on the prosperity of which the agrieultural labourer depends.

A tegal minimum wage for agrieultural labourers, though it would in effeet tax the landlord right hearily, is open to none of these objections. It would achiere its object directly, and not indireetly. It would go, every penny of it, straight into the poekets of those who need it most, and for whom it is intended. It is the key to the whole problem of rural development, which without it cannot be, and which with it will eome almost of itself. Not one elass only, but all elasses, not agriculture only, but the whole community, will share the prosperity which will ensue when a living wage abolishes, once and for all, the waste of material that is so pitiful a feature of modern village eon ditions, and brings at last the opportunity of eivilised life to the children of the soil. 


\section{CHAPTER IV.}

\section{TIIE SOLUTION OF THE COTTAGE QUESTION}

I

T has been made clear in the preceding pages that the rents of cottages are only low in many rural districts partly because many of them are old, insanitary, and overcrowded, and partly because they often belong to the employers who charge a low rent instead of paying a higher wage. There is no possibility of extracting from the present wage of the agricultural labourer a sufficient rent to make the building of new cottages a commercial undertaking. The result of this is that the natural expansion of the countryside cannot take place, and new cottages cannot be built execpt by philanthropic landlords in cxeeptional eases. But new cottages must be built, and rapidly, if the decline of the countryside is to be arrested. Before deciding on how this end can best be achieved, it is necessary to understand the state of the existing law, and what the financial problem is.

\section{§1. The Existing Law.}

The two prineipal Acts of Parliament which deal with Housing are: (a) The Housing of the Labouring Classes Act, 1890 ; (b) The Housing and Town Planning Act, 1909.

The effect of the latter Act was: (a) To make it compulsory on Local Authoritics to hold an investigation of all cottage property in their areas, whereas the former Act made such an investigation optional; $(b)$ to give the L.G.B. greater facilities to foree the local bodies to take action than had been the case heretofore; $(c)$ to give Local Authorities greater facilitics for building than under the Act of 1890.*

* The principal sections in the II. \& T.P. Act, which should be noted in this eonnection, are sections $1,3,10,11,12,17,18,37,73$. 
'The Act of 1890 being optional was valueless, and liardly ever applied. From 1890 to 1909 only nine loans to six R.D.C.'s were granted for the crection of labourers' dwellings under the Act.

Under the Act of 1909 considerably more has been effeeted. From 1909 to August, 1913, 71 loans have been sanctioned in respect of 37 R.D.C.'s for application in 54 parishes, amounting to $£ 87,662$; whilst further schemes amounting to $£ 110,000$ were under consideration by the Board in August.

Thus 5\& R.D.C.'s have becn stirred into action under the later Aet from 1909-1912, as compared with six R.D.C.'s under the prior Act from 1890-1909.*

Taking the figures as comparative, the progress appears good; but in view of the enormous dearth to be made good, little has really becu achieved. $\uparrow$ The Act is virtually uscless to deal with the rural housing problem, for the reason that the rents of eottages built under it are too high for the ordinary labourer. The rents have averaged between ss. $6 \mathrm{~d}$. and $4 \mathrm{~s}$. a weck, while in many cases they have been much ligher, 4s. 6d., 4s. 9 d., and even in some cases $6 \mathrm{s. \ddagger}$

\section{§ 2. Thie Financial Problem.}

There are one or two fallacies which have drifted into . almost general aceeptance in connection with cottage

* L.G.B. Annual Report, 1912-1913. Cd. 6981.

† In one respect the operation of the Sanitary clauses of the Act has only made the housing problem more aeute. Up to March 31st, $1912,28,667$ houses in rural districts were represented, under Section 15, as not being in all respects reasonably fit for habitation. Of these 14,626 were patehed up, but 722 were closed altogether, and 9,740 notices werc still in abeyanec, owing to scarcity of cottages in the neighbourhood. During the thrce years ending March 31st, 1912, 33,453 cottages were represented as being unfit for human habitation. Of these 3,270 were compulsorily elosed, and 14,255 either patched up or closed or demolished voluntarily without the issue of an order. Thus 3,992 cottages hatc been compulsorily closcl, large numbers of others voluntarily closed or demolished, but up to October 31st, 1912, only 398 new cottages had been built in their place. 1)uring the past ycar the same process of closing has gone on apace; but the loans at present sanctioned since 1909 only provide for the ereetion of 4.50 cottages.

$\$$ White Paper No. 293, issued by L.G.B. August 1st, 1912. 
building, and these it is well to clear out of the way before investigating the question as to what a cottage costs. Some people, especially politieians, speak as if the landlord, by withholding land altogether, or by asking too high a price for it, rendered eottage building impossible. There are doubtless cases in which, for his own selfish purposes, the landlord refuses to sell land for cottages altogether, but they are ecrtainly not very frequent where the land is wanted for agricultural labourers' cottages only, and they could, and should, be met by powers of eompulsion.

Speaking gencrally, the high priec of land eannot prevent cottage building. Let us take an extreme case. Let us suppose $£ 100$ an acre be asked for land that is only worth $\{25$, and let us assume that only 4 cottages are built on that acre, 18 15s. will be added thereby to the cost of caeh cottage, a sum whieh would only add a few pence to the rent per week. The addition of $£ 10$, or even $£ 20$, to the price per acre would make less than a penny differenee to the rent.

The same argument applics to the extra cxpense involved by rather stupid and inclastic byc-laws, and again to the high wages in the building trade. The differenec in the cost of a cottage if you pay a trade union rate of wage to the men is very small, seeing that the wages bill is not more than 30 per cent. of the whole cost of the cottage, and the differenee between high and low wages only a fraction of that again.

It is evident, then, that all the causes to which is popularly aseribed the lack of cottages, high price of land, expensive byc-laws, and trade union rate of wages, cannot, if taken together, involve $G d$. a week addition to the rent, and, as a matter of lact, in most cases they simply do not exist. The dearth of cottages is due simply and solely to the low wages of agricultural labourers, who cannot afford to pay for them; aggravated perhaps by our rating system.

What, then, is the actual cost of cottage building at the present time?

The Sclect Committec, previously quoted, stated in their Report that they "felt justificd in laying down the general proposition that cottages built in a pair ean be erected at something between $£ 150$ and $£ 175$ each to meet all the 
requirements of a reasonable code of bye-laws. But this could not include the cost of land, nor the provision of a water supply where none exists."

There is no doubt that, in eertain localities, eottages have been built more eheaply than this. But it does not follow that because a building has been ereeted for a certain sum in one district it ean be duplicated somewhere else for precisely the same price.* Moreover, the eost of building rose 30 per cent. between 1887 and 1912, and is still rising rapidly. After the coal strike prices went up enormously, and have not yet come down to within 10 per cent. of their previous level. $\dagger$

Experiments are oceasionally made with special materials, and it is not unreasonable to hope that some cheaper kind of building may supersede brick, which up to the present holds the field as the most obvious material for cottage building.

In view of the evidence it is impossible to estimate the cost of 5-roomed t cottages, even when built in blocks of four, at less than $£ 200$ apieee. Now an ordinary person who builds eottages would want at least 5 per cent. on his money after paying all outgoings, and most people want 6 per cent., or more, owing to the risk of losing rent which is involved. Suppose the cottage (3 bedrooms) cost $£ 200$ to build with the land, rent would work out roughly something like this :

\begin{tabular}{|c|c|c|c|c|c|c|}
\hline 5 per cent. on $£ 200$ & $\ldots$ & ... & ... & ... & $\begin{array}{c}\mathcal{E} \\
10\end{array}$ & s. \\
\hline Rates 4 s. on, say, $£ 8$ & ... & ... & $\ldots$ & ... & 1 & 12 \\
\hline Repairs, say & $\ldots$ & $\ldots$ & $\ldots$ & $\ldots$ & 1 & 0 \\
\hline Water rate (if any) & $\ldots$ & $\ldots$ & ... & $\ldots$ & 0 & 8 \\
\hline Empties (none if good & locality & & $\ldots$ & ... & & \\
\hline Collection $\quad \ldots$ & $\ldots$ & ... & ... & ... & 0 & 13 \\
\hline Insurance & $\cdots$ & $\cdots$ & $\cdots$ & ... & 0 & 4 \\
\hline
\end{tabular}

This works out at approximately 5s. 4d. a week. Ignoring the collection and water rate, which might be avoidable, the lowest rent at which a cottage can be built to pay may be stated roughly as 5 s. a week.

\footnotetext{
* The Cheap Cottage. G. Gondon Allex. Garden City Press, Ltd. $\uparrow$ See Appendix I.

¥ One cottage in five could be built with only two bedrooms
} 


\section{§3. A Government Housing Grant.}

The calculations of the needs of the average family, above given, prove that if 5 s. a week be paid in rent, nothing less than 25s. a week will provide even the neeessaries of life, and any diminution of that wage will also render void the hope of bettering the housing of the labourer on economic lines. To anyone with a knowledge of agricultural conditions, an attempt immcdiately to raise wages all over the country at onee to 25s. must appear fantastic. Some other method of solving the problem must therefore be found, and the only other possibility that offers is that of a Govermment Grant in aid of Cottage Building.

There are very serious objections to the policy of subsidising cottage building. Anything which tends to stereotype the present low wage is bad; and a Gorernment Housing Grant of a kind which would enable the labourers to continue to accept their present wage would be a grant in aid of the owners of land, or of eapital, or of both. Again, if really cheap cottages be provided at uneconomic rents, all other cottage building will automatically cease, and the State will find itself eompelled to re-house Great Britain. Whereas, if the grant be given under conditions which compel the Local Authority to keep their rents as nearly ceonomic as possible, this will prevent the plan from being immediately and widely effective.

On the other hand, the following weighty points must be borne in mind :

(i) 'The improbability that a minimum wage really sulfieient to stimulate cottage building will come at once.

(ii) The terrible consequences in health and waste of life every yeur that the present overelowding, and bad housing, and lack of housing continue.

(iii) The experience of Ireland,* and the transformation

* The Irish Labourers Acts (1883-1906). Labourers' cottages in Ireland are at present built under the $\Lambda$ ct of 1906 , as amended by the Aet of 1911.

Under these Acts :35,409 cottages have been ereeted, and 5,057 are now in proeess of erection, a total of 40,466 cottages in all, and the total loans granted for this purpose to date amount to $\$ 27,860,939$.

Under the 1911 Act provision is made for the advance of a total sum of $\$ 5,250,000$ by Artiele 12, Land Commission, by way of loans to 
which experts and casual visitors alike describe as almost magical, which has taken place in the districts of Ireland where the need was greatest, and where eottages have now been supplied. Not only has the standard of life been swiftly and surcly raised, and acute poverty been superseded by prosperity, but the character and independence of the population affected has been developed and strengthened in a truly remarkable degree. So far from pauperising the peoplc and keeping them in serfdom, as theorists predieted, they have been put in a position to fight for themselves, and have begun to do so.

In view of this evidence it is elear that, in spite of any economic prejudiees, something resembling the Irish policy must be adopted in England as well. A high minimum wage, if it could be obtained. would be the best solution; and no policy of subsidy should be adopted without the passing of a minimum reage law to prevent the subsidy being a mere bounty from the National Exchequer to the employers of sweated agrieultural labour. But as practical people we must advance along both lines at onec; and it may well transpire that the one policy, so far from frustrating, will actually play into the hands of the other.

And as for theory, municipal cottages, if accompanied by a minimum wage sufficient to cnable a man to pay a rent which will cover the bare cost, should afford a magnificent

the R.P. Councils for the purposes of the Acts. The State aid takes the form of a grant of 36 per eent. of the annual charge in respect of cash loan to a Couneil ; and at the present moment a sun of $£ 81,336$ is thus paid annually from the Exelıequer to Irish IR.D. Councils. The rents charged for these cottages vary from $9 \mathrm{~d}$. to $1 \mathrm{~s}$. $6 \mathrm{~d}$. per week, and to many an aere of land is attached. If we take the average for the whole of Ireland, we find that the expense is borue in the following proportions : Rents, 44.5 per cent. ; rates, 24 per cent. ; State contributions, $31 \cdot 5$ per cent. ; making a total of 100 .

The eost of the cottages varies from $\$ 120$ to $£ 200$.

The price per aere of land averages between $\$ 25$ and $\$ 50$, though it sometimes amounts to $£ 100$; it works out about 25 per cent. above the agricultural price.

The average rent is $1 \mathrm{~s} .3 \mathrm{~d}$., and varies from $9 \mathrm{~d}$. to $1 \mathrm{~s} .6 \mathrm{~d}$.

In some cases there have been grants from the local body to buy a cow, provided the milk is kept in the village.

It is remarkable that in County Cork, where an exceptional number of cottages have been built, the wage has increased more than elsewhere. 
opening for a sound business on Socialist lines, conducted for use and not for profit by the Community itself, a business which might soon be developed so as to provide not only cottages, but larger houses as well.

The ehief value of grants-in-aid is that they become a le ver by which the eentral authority ean foree the local authority into action. And in this case the lever should be drastically used. For instanee, the State should issue peremptory instructions for an expert survey * by an officer of the District Council, acting with an offiecr to be appointed by the Local Government Board. No grants for any service should be receivable by the District Couneil, or Board of Guardians, after six months from the passing of the Act, until such survey is presented. It should also make peremptory provision that any defieiency in sanitary dwellings revealed by such survey shall be made good by new eottages, by whomsoever built, within a year from the survey. The District Council must build if no one else does, and should receive loans at the lowest rate of interest $\dagger$ from the Public Works Loan Board for the full cost, and sinking fund. It should also receive annual grantst equal to the whole paid for sinking fund and

* Such a survey, periodically revised, is in practice in Holland, Germany, France, and Belgium.

$\dagger$ 'The rate of interest is most important, as it is fixed periodically by a Treasury Minute, and has been as low as 23 per cent., and as high as $4 \frac{1}{4}$ per cent. The difference, namely, $1 \frac{1}{2}$ per cent., would make a difference of 1 s. 2 d. per week in the rent of a $\$ 200$ cottage. The Report of the Select Committec points out that the Post Oflice Savings Bank Depositors only receive $2 \frac{1}{2}$ per cent. on their money, amounting at that time to $£ 150,000,000$, and that tlic Official Trustees had $£ 20,000,000$ of charitable funds in hand at $2 \frac{1}{2}$ per cent. They suggest that there is no reason why this money should not be employed for so necessary a public undertaking as cottage building.

+ The distinction between annual grants, as here advocated, and capital grants on the lines of the Irish Labourers Aets is important, and is well expressed in a memorial presented to the l'rime Minister in July, 1913, by the Executive Committec of the National Land and Home League : "We do not advocate a capital grant on the lines of the Irish Labourers Acts, because a rise in agrieultural wages, which we believe to be an urgent neecssity, would result in a part of the capital expenditure passing into the hands of the local authorities should wages rise sufficiently to allow a payment of ceonomic rents by the agricultural labourer. We therefore advocate instead an annual yrant to meet a part only of the loss incurred by local authorities, in order that these authoritics may have a motive to raise their rents as wages go up until the cottages are on a commercial basis." 
half of any deficit on the annual account, if the Local Gorernment Board is satisfied that such loss is inevitably or properly incurred. No grants-in-aid should be receivable for any service after two years from the passing of the Act until the necessary cottages are built.

The effects of these recommendations would be that in every locality eottages of a modern type would be readily obtainable at 3s. a week without any charge on the rates at all, and if for special reasons the loeality thought fit to charge less rent still in certain distriets, half the loss would be made up to them by State Grant, provided that the Local Government Board approved of the policy adopted. The total cost to the nation would be the amount of the sinking fund only, plus the annual grants-in-aid of rates in the special eases just mentioned. The fact that the locality ould bear half the cost in thesc cases would prevent the Local Authorities from adopting such a policy except when necessary. Supposing 100,000 cottages were thus built by Local Authorities at an average cost of $£ 200 \mathrm{cach}$, and that the period of redemption was extended to eighty years (at present it is only sixty for the cost of erecting buildings, and eighty for the purchase of freehold land); then if the cottages were let at an average of 3s. a week, the annual grants would amount to $£ 250,000$. If 25 per cent. of the cottages were let at 2 s. instead of $3 \mathrm{~s}$., the sum would be increased by $\mathfrak{i 6 5 , 0 0 0}$ a year.

Here you have the policy of the National Minimum applied to rural housing. Defective cottages must be put right; sufficient new cottages must be built; otherwise no grants for any service whatever to be receired by the Local Authorities concerned. But to enable these things to be done, every facility should be given in the form of new grants-inaid on the conditions above laid down. A thumping fine for backward districts: a thumping bribe for progressive districts: thus making a forward policy, whieh is really the most economical to the nation as a whole, also the most economical to the locality concerned. This is the true business policy on this question. 


\section{CHAPTER V. \\ TOWARDS NATIONALISATION}

§ 1. Sentimextal. Value.

$I^{\mathrm{T}}$

I' is not possible to diseuss satisfaetorily any poliey for rural distriets without taking into aceount the three interests eoncerned-the interests of the landowner, the tenant farmer, and the labourcr. Under the existing land system, with feudalism still a reality, the three interests are closely conneeted. By feudalism is meant the possession on the part of the landowner of peeuliar privileges, power, and position, in return for which he is supposed to render certain serviees, such as providing cottages at uneconomie rents, assisting in paternal fashion the poorer tenants, and generally spending money in ways that provide a eonsiderable amount of locil employment. Feudalism is, no doubt, on the decline, and must disappear. But if we attempt merely to hasten this disappearanee without having anything exeept individualistic enterprise to take its place, it is ecrtain that there will be, at any rate for a time, no little suffering in rural districts. A eonstruetive policy must aceompany the policy of destruetion.

Any eonstructive poliey must satisfy two conditions. First, it must improve the position and increase the number of the rural population. More moncy, and not less, must therefore be spent in rural distriets. Mere taxation, to be spent on inereased armaments and the like, will not suffiee. Secondly, it must lead on to Nationalisation. We do not want, for its own sake, the break-up of large estates and their sale to tenants. The fewer the owners the easier to nationalise and control.*

* There are at present only 5,000 large landowners in England owning over 1,000 acres; and these 5,000 own nearly half the land of England letween them. The whole of the soil is owned by about $1,000,000$ persons altogether. In both Germany and France, on the other hand, the ownership is more equally divided among about $5,000,000$ persons. 
There are at this moment some 12,000,000 acres of poorly laid down, neglected, unproductive grassland, which could be put to much better use *; and this deplorable fact is not due, as is often supposed, merely to the selfish sporting instinct of the landowner, but rather, as has already been stated, to the extensive methods adopted to meet the period of depression, involving the employment on the land of less labour and less manure than the conomic minimum. As a set-off against this eonsequent reduetion in the ceonomic value of the land, many estates have acquired what may be called a sentimental value. By this is meant the price the owner is willing to pay for feudal privileges, social position, and the like, and for the possession of a thing of natural beauty such as is many an old estate in this country. This sentimental value may easily amount to 40 per cent. of the total selling value of the estate, and part of it is actually due to the uneconomic way in which the estate is managed. If the pasture of a large park were cultivated intensively, each acre of that park might produce five or six times as much, but the total selling value of the estate would be considerably reduced.

Now, the fact of the existence of this large sentimental value is a strong argument against any extensive scheme of Statc purchase at present prices. $\uparrow$ But there are signs that this sentimental value is destined to decline rapidly. The position of the landowner is less attractive than it was;

* Laind Problems. By Curistopher Turnor, p. 17. (John Lane, 1911.)

$\uparrow$ Mr. Chiozza Money has rightly pointed out that, speaking generally, land is cheap in this eountry. One hundred pounds an aere, for instance, is really eheap, not dear, as compared with the price of money. If you build ten small houses on land worth as mueh as $£ 500$ an acre, the cost of each house would be as follows :

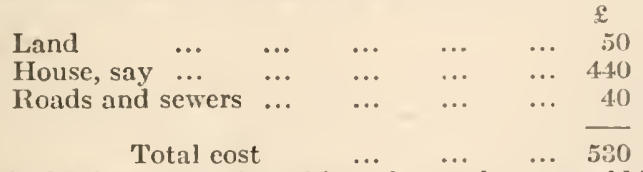

Now, if the land were worth nothing, the total cost would be reduced

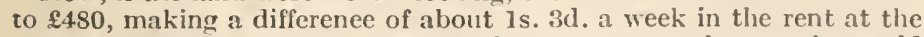
outside. But if the money were only 1 per eent. eheaper, it would make a differenee of $2 \mathrm{~s}$. a week. Cheap money is much more important even than cheap, land. 
his feudal privileges are disappearing ; new taxes and threats of taxes are unpleasant.

A big drop in sentimental value is, in itself, all to the good. It is desirable that ceonomic and selling value should approximate. But unless some eare is taken, this process will entail considerable temporary suffering, both to tenant farmer and to labourers, especially where owners have no other resourees than those derived from the land. The way this oceurs is obvious. 'The Finance Act of 1909, for instance, not only inereased the rates of the Death Duties, but also, which is far more important, ehanged the method of estimating the value on which they are based. The result of this has becn, in many eases, to double or more than double the amount to be raised. In order to meet this extra prospective burden, a mortgage would probably be raised on the estate, and an attempt made to redeem it in fifteen years, thus involving an annual charge on the estate of a considerable sum. This annual eharge would be met by the owner by a corresponding reduction in expenditure, involving primarily a reduetion in the wages bill, and the consequent discharge of a large number of people.

The moral of this is that some eonstructive policy for the land must aceompany the burden that is at present being placed on landowners, unless this is to involve a decrease in the amount spent on afforestation, buildings, cottages, and other improvements, and a eonsequent sudden and considerable reduction in the amount of wages paid.

\section{§2. Land Purcilase.}

Without a constructive poliey similar undesirable results would also aecompany the proposed minimum wage law. Such a law, followed by a corresponding reduction in the rent of agricultural land, would tend to strip such land of sentimental value, and reduee its value to an economic level. The landowner might feel himself obliged, in some eases, to allow land to fall out of cultivation. The time would then be ripe for a scheme of State Land Purchase, which would meet the landlord's complaint that he was foreed to keep land on which all the profits had been wiped out, and 
which would at the same time provide for derelopment by the community of land that private owners could not cultivatc. The poicer to acquire land for the community at a valuation is the next most important step in the solution of the rural problem.

The ideal of the single tax and the ideal of complete land nationalisation are both so far off as not to demand a searehing examination herc. But the first steps towards these ideals, viz., the proposal to tax land values, and the proposal to give the eommunity sweeping powers of purchase for any purpose-except that of selling again to a private individual -are both immediate and practical; of these the latter is by far the more neeessary of the two. In purely agricultural districts the site value is a negligible quantity.

The landlords of the country derive their ehief wealth from the need of the workers to have room to live, and the need of industry to have space for production and distribution. The Land 'Taxer proposes to make the landowner pay heavily for the privilege of restricting these needs; and argues that sueh taxation will result in loosening the bonds of private ownership, and minimising the restrietion of the needs. But this could be achieved more directly and effectively by giving to the community power to acquire belts of agrieultural land round the towns, and the means of locomotion and transit for their full derelopment; and in purely country districts by providing machinery to secure for the public all land which is not being properly developed, or which is required for housing, small holdings, or any other public purpose. If men are rich, whether as owners of land or any other form of wealth, tax them. If they are publie nuisances, whether by holding up land or in any other way, coerec them. But to mix up the two processes only leads to confusion.

To what extent land is actually held in private hands which is either not fully developed or of which the community has need for its own purposes will subscquently become more evident. It is suffieient for the moment to know that such a position exists; and the fact of its existence fully justifies a free community taking steps to put an end to it. All that is required for that purpose is a short Aet of 
Parliament, on the lines of Section 10 of the Housing and Town Planning Act, applying to local conditions generally and to the development of land. This would give power to a few inhabitants of any district to call machinery into play which would bring about an inquiry into the management of the land in question, and sceurc it, if necessary, lor the community at a reasonable price, based on the valuation now bcing made.

But though this simple proceceding could be thus simply carricd out, the time is ripe for a far larger application of the principle that land, as the physical basis of all life, should be at the full disposal not of private individuals, but of the community as a whole. This principle has been recognised in successive Acts of Parliament compelling private individuals to surrender land for public purposes. What is now required is not merely, as above suggested, to extend the principlc to cases where land is not fully developed or is immediately needed, but to prepare a way for securing to the land-users of the future that they shall be subject to no restrictions as to the use of their land execpt such as arc imposed upon them as tenants of the public, for the sake of the public; and at the same time for placing all land at the disposal of the community, as landlord, with power to pursuc a policy of national development. And for this purpose full powers should be given to the public departments and to the local bodies to acquire land not merely for present, but in anticipation of future uses.*

These powers involve the ereation of a National Board of Land Commissioners for the purpose of land purchase, to undertake the work of all the public authorities concerned. Such a Board should have power to purchase land compulsorily; and the present landowners should be safeguarded by a right of appeal to judicial authority, and also by the right of any landlord to sell land to the Commission at the approved purchase priec. This right should be subject to one important restriction, without which the State would find

* Speaking generally, the local authority is the proper authority to purchase for special purposes, and the State for general purposes. A loeal fall in the value of land would severely hit a local authority; but there is no general fall in the valuc of land, so the State could not be a loser. 
itself the owner of all the worst land, as this is what the landlords would be most anxions to sell. To avoid this, the Commission should be able to refuse to purchase unless the area is, in their opinion, suitable for reletting sueessfully. For instanee, seattered small looldings are of less value than one area of small holdings which ean be grouped together for purposes of eo-operation. Therefore the Commission, il asked to buy one small holding, should be able to refuse until -either by use of their compulsory powers or by the landlord yiclding-they could obtain a suffieient area for several.

There would be no diffieulty in administering the land either by the loeal authorities or by the Land Commissioners themselves. They would in some cases hold it and work it by an agent, as other landowners do ; but more frequently they would let it off for long periods, either in small holdings or in larger areas, retaining the power of redemption and guaranteeing a full eompensation for improvements.*

In answer to the fear of the finaneial magnitude of the above proposals, it is sufficient to point out that the nationalisation of the whole of the land of the country at onee-which is not what is proposed-would not be a much bigger operation than the late Lord Gosehen's Conversion of the National Debt.

As in the ease of many of the Irish landlords, payment. would be made with guaranteed land stock. The owners of the London Docks were similarly paid with Port of London stoek, and many of the shareholders in the old water conpanies were compensated by receiving Water Board stock.

Private ownership of land has so long been tolerated by publie opinion that it is only fair to the present owners that they should be bought outright, if they are displaced; at the same time, to buy the land at the sentimental value at present attached to it would be a very bad bargain for the community. The direet purchase of land by the Commis-

* "I have let over 7,000 acres in allotments and small holdings during the last five years. I have improved and adapted 28 existing louses, and built over 80 new smallholders' houses, and forty-four new sets of buildings have been provided, while, as the result of improved management and judicious eeonomy, the net income from the property lias inereased by $\$ 10,000$ al year" (from a speech by Earl Carrington, now Lord Lineolushire, when he was President of the Board of Agrieulture). 
sioners, whenever it is actually wanted or appears to be likely to be wanted by the public for any purpose whatever. at a price based on the official valuation. is the fairest method that can be desired of gradually gaining for the nation, with the minimum of individual hardship, that which to the nation rightly belongs.

\section{§3. The Irredeemable Mortgage.}

There is one other step that miglit be taken in the same direction. Under the Finanee Act of 1909, the State may, with the consent of the owner, take a proportion of the estate as payment for part or all the duty. It is not, however, probable that much use will be made of this provision. It would be inconvenient to the State to have fragments of estates seattered all orer the country. A development of this principle of payment in kind is quite feasible. Where the State does not take land it might, instead of requiring eash, aecept from the owner a mortgage on the estate to the amount of the duty due. This should be obligatory on owner and State alike. The mortgage should be irredecmable, and would constitute a permanent charge on the estate. The owner could probably obtain a mortgage in the ordinary way at 4 per ecnt., and the State might require this rate of interest, or, if it wished to popularise the practice, might accept $3 \frac{1}{2}$ per ecnt. It should be open to the State at any time to aceept land to the value of the mortgage, but it should not be permitted to acept cash. The mortgage would be attached to the land, and if parts were sold, should, in due proportion, attach itself to these parts. The Government valuation would make the apportionment easy.

The advantages of this proposal are many :

(i) The owner, being unable to free the estate from the charge, would not find himself driven so hard to obtain an inereased income from the estate by a sudden reduction of expenditure to meet a redemption fund. Of eourse the eharge would be permanent. But we should avoid to a considerable extent the danger of such large reductions of staff and expenditure.

(ii) A permanent eharge attached to land value would have 
beneficial effects. It would tend to decrease the value of land by more than the amount of the mortgage. From the point of view of sentiment land would, in the circumstances, become a less desirable object. There would be a gradual decay of sentimental values. This is desirable. The price of land, an article of necessity, should not be enhanced by a 40 per cent. load of sentiment.

(iii) The State, by acepting a mortgage instead of a capital sum, would be temporarily a loser. This also would be desirable. There was always some ground in the objection raised in connection with large Death Duties that they were taking capital for annual expenditure. The irredecmable mortgage would not be open to this charge. It would also have the additional advantage of compclling the State to resort to a larger ineome tax.

(iv) But perhaps the greatest advantage of the proposal lies in the fact that it leads gradually to Nationalisation. It gives the State an interest, and a rapidly inereasing interest, in the land. In any particular case the State might acquire an interest equal to, say, 12 per cent. of the selling value, and considerably more than this pereentage of cconomic value, which will, when sentiment is dead, represent the ultimate value. As the mortgage is irredcemable, and as the rate of duty depends on the valuc of real and personal estate together, the State would, in a comparatively short time, possess a major interest in the land. By this time the sentimental value would have disappeared, and the selling and ceonomic value be the same. It would then become a question whether the State, possessing so large an interest, should not on terms acquire the whole. This proposal of an irredeemable mortgage would represent a policy of gradually buying out the landowners with their own money. 


\section{CHAPTER VI.}

\section{SMAI,L HOLDINGS.}

7 HE recommendations hitherto made have been aimed first at levelling up the standard of life of the la1 bourers on the land, and, secondly, at securing for the shadow a policy of development under which the whole position of agrieulture would be transformed, and by which the countryside would inherit, though in different conditions, a double measure of its lost prosperity. It is hopeless to expect any policy of development while the work of agriculture is built upon sweated labour and an ill-fed population, or while the fount of rural wealth is drained by private interests. But, on the other hand, it is futile to remove these obvious impediments, exeept as a preparation for a definite national policy of land development. Such a policy to be complete must give free aceess to the land to all who desire it, and a fairer opportunity to all who have the aecess now ; must ereate order out of the chaos and muddle that stamps the production and distribution of our agrieultural produce; and must organise and bend to the service of the nation the full energies of the labourer, the small holder, the large farmer, and the State as well.

\section{$\S 1$. Tiie Case folr Simall Holdings.}

At the time of the Norman Conquest, and for some eenturies after, the whole of the peasantry-generally speakingowned or oceupied land. But in the thirteenth eentury, ${ }^{*}$ and perhaps earlier, the great economic morement commonly ealled the Enclosure of Commons began, and continued for over 600 years, until by 1850 it was praetically

* Statute of Merton, 1235. 
complete, with the result that large holdings and larger ownings had been substituted for small looldings and the complicated manorial system of owning.

There is no doubt that the main factor in this great agrarian revolution was economic. This is shown by the fact that consolidation and enclosure of holdings went on in all sorts of ways, and was promoted by all classes of people. In some counties-Kent, Essex, Devon, and Cornwall-it took place so early and so completely that very little is known about the process. Elsewhere it was brought about by exchange, by purchase and sale, and by general agrcement amongst the peasant occupicrs themselves, and * later on by landlord aggression, by private Acts of Parliament, and, finally, by provisional order.

The old three-field system was wasteful of labour, prevented agricultural progress, and maintaincd a low grade of cultivation. It had to go. During the eighteenth century the growing population increased the demand for corn, which is best grown on a large scale, and until about 1880 all the efforts of the State to counteract economic pressure, efforts cxtending from the days of Elizabeth to the Allotments Act of 188\%, proved vain. Big farms paid best, and the small farms and small holdings had to disappcar.

But in 1850 the tide turncd, + wheat began to fall rapidly in price owing to the reduction in the cost of carriage; the wheat farmers lost money, and the grazicrs, for a similar reason, were in no better case. The turn of the small holder had come. The home-grown produce which England wanted was fruit and flowers, vegetables and eggs, milk and butter, all things which can perhaps be produced best on a small scale, except indeed the last-named pair, which can be produced profitably by large holders and by small.

Small holdings pay because our big towns now demand what small holdings can best supply; and failing to get it, they import it from abroad. Our soil is undercultivated!

* See R. H. TAwney, The Agrarian Problem in the Sixteenth Century, 1912. See Levy, Large and Small Holdings. Also Jourson, The Disappearance of the Smallholder.

$\dagger$ See Levr, Large and Snall Holdings. Also Joussos, The Disappearance of the Smallholder. 
Our produce is under $\mathfrak{f} 4$ per acre of all cultivated land, grass, and arable.* Part of the 12,000,000 acres of pasture is not being turned to proper account. The sheep farming average is high cnough, but this is not true of other stock. The liead of stock has not increased of late years in proportion to the amount of land laid down to grass, which means that land is going out of cultivation. A far higher head could be carried. $\dagger$ We want the big produce per acre - $£ 20$, it is said, $\ddagger$ in Belgium-which small holdings and intensive culture alone can producc. The intercst of the country and of the landowner arc not necessarily identical in this matter. The landowncr prefers the largest net return, and the farmer also seeks the same thing. A big grazing farm, employing next to no labour and very little capital or supervision, may give only $£ 3$ an acre in produce and yct yield more profit to the farmer and rent to the owner than arable producing crops worth $£ 12$, whose cost of production in labour and capital is $£ 10$. But from a national standpoint, production of $£ 12$ an acre is obviously preferable to $£ 3$. And the small holder who is to make a living of $25 \mathrm{~s}$. or 30 s. a week off twenty acres must cultivate intensively and produce per acre far more than the average farmer does to-day.

This is the justification of the policy of the Small Holdings and Allotments Act, 1908. But the main argument for small holdings is not, after all, an economic one. There are other and valid reasons why the State should deliberatcly sct itself to increase the number of small holders.

In the first place, we want to put a stop to rural depopulation. It may not be true, though it is often asserted, that the family of a labourer in a big town dies out after three

* The yield per aere in Germany is $£ 55 \mathrm{~s}$. ; in France, $£ 5$ 9s. ; in Denmark, just under $£ 6$, and in Belgium, $£ 20$. See Land Problems. By Curistopher Turnor.

$\dagger$ The live stock per square mile in the various centres of Europe is as follows: Belgium, 180 ; 1)enmark, 160 ; Great Britain, 133; England and Wales, 160 ; Seotland, 76 ; Germany, 117 ; Franee, 95. The milk cows per square mile are: Belgium, 76; Denmark, 71 ; Germany, 50 ; Franec, 36 ; Great Britain, 30. (See Mr. Rowntree's Land and Labour; Lessons from Bclgium. Maemillan, 1911.)

$¥$ On the authority of M. Vuyst, Inspeetor-General of Agriculture in Belgium. 
generations. But it can hardly be controverted that a pcasantry, if properly housed and fed, is physically stronger than a town population under any conditions likely to be universal within the next few years. All vital statisties, and emphatically those of infant mortality, point to the superiority of country life. Intellectually, the life of a large town is unnatural in this sense, that the human race and its ancestors, during all time up to a century or so ago, have lived in the country, or within a mile of it, and the life of a dweller in a city wholly cut off from the sights and sounds of what Mr. II. G. Wells rightly calls the normal life is a new and disquieting phenomenon.

For centuries past statesmen have at intervals legislated against rural depopulation, * and there is no doubt that their instinct has been sound. Now this may be laid down without fear of contradiction, that cnterprising and self-respecting men will not stay in the country if they can escape. They will not bring up their sons to be agricultural labourers whilst their only prospect is a hard and narrow life on a miserablc wage of 10 s. to $20 \mathrm{~s}$. for a long day, seven days a week, and nothing better than an old-age pension to hope for at the end of it. The life of the proletarian in the big industries is hard enough, and is ill recompensed with his wages of 20 s. to $40 \mathrm{~s}$. a week. But it is better than the semi-scrfdom of the farm labourer, who gets half his wages, and has at the same time to touch his hat, go to church, vote as he is told, and generally sell his soul as well as his labour power to his employer and the other rulers of the parish. If men are to be kept in the country they must have a chance to get land, to build up a permanent home for themselves in which they ean bring up children and grandchildren, and to which they can look forward as a resting-place for old age.

Again, small holdings tend to raise wages and increase the prosperity, or rather prevent the decay, of village trade and industry. They raise wages because the small holder is often also a labourer, but a labourer who will only work for others if it is made worth his while to do so. Even allotments give a man some security against unemployment, some 
resource other than his weekly silver. Whatever makes the labourer independent tends to help wages up; and the smallest scrap of land, let alone a small holding with a county council cottage, turns the farm hand into a man.

As for village trade, it is scarcely necessary to point out that the small holder-at any rate till his co-operative society is fully at work-is a customer (and a good onc) for all that the village tradesmen supply: he has horses to be shod, a cart for the wheelwright, baskets and string, pigs' food and hens' food, and better clothing for himself and his family. Even if he buys co-operatively, the carriage has to be done by existing methods. Far more money circulates through a twenty-acre small holding with farm buildings, a cottage and intensive culture, than is turned over by an agricultural labourer on 15s. a week and the same twenty acres in grass feeding cattle or arable growing corn.

Socialism has been defined as giving peoplc what they want. Some who believe that good things are always disagrccable, and retain their faith in the inborn depravity of humanity, demur to the definition; but provided it be not pressed too far, or taken too literally, it is on the whole sound. Now there is no sort of doubt whatever that the people already in the country want land. Every village is full of men who are eager for the chance of hiring anything, from a little allotment up to a small farm of fifty acres. They want to stay in the country. They want to grow their own potatoes and keep their own pigs and fowls. They want to work for themselves the land they have spent their lives-so far-in tilling for others.

It is a grand thing to satisfy that widespread, deep-rooted desire for land, * that genuine land hunger of the British peasantry-and not of the peasantry alone, but of the small tradesmen and artisans of the villages and country towns. The people of England will be healthier, wealtinicr, wiser if more of them are in contact with the soil, not as mere daylabourers toiling for others, but as occupicrs at a fixed rent farming for themselves.

* Not a desire for ownership of land necessarily, as Mr. Belloc and his sehool mistakenly assert. 


\section{§ 2. Tine Siall Holdings ACt.}

The ery of "Back to the Land" may be very largely political eant, but it is based on a solid foundation of truth, of which the evidence is to be found in the working of the Small Holdings Aet of 1908. The annual report of the Small Holdings Commissioners, published in May, 1913,* gives full particulars of land aequired for small holdings under the 1908 Act. Briefly, to summarise, since the passing of the Act up to December 31st, 1912,

\begin{tabular}{|c|c|c|c|}
\hline 104,533 & , & ", & purchased for $£ 3,385,262$, and \\
\hline 50,414 & , & , & leased for $£ 63,528$; \\
\hline 124,709 & ," & , & let to 8,950 individuals ; \\
\hline 212 & ", & , & sold to 20 individuals ; \\
\hline 6,094 & , & , & $\begin{array}{l}\text { let to } 49 \text { co-operative small holdings asso- } \\
\text { ciations, who have sub-let to } 967 \text { of their } \\
\text { members. }\end{array}$ \\
\hline
\end{tabular}

In addition, 37,000 acres have been provided for 2,954 approved applicants by private landowners direet, mainly through the instrumentality of the councils, and 1,586 acres have been let to 192 individuals and 63 members of eooperative associations by councils of county boroughs.

The total number of applicants satisfied in five years is 15,176 and the number approved, but not yet satisfied, is 8,508 .

The average price of the land purchased is $£ 327 \mathrm{~s} .8 \mathrm{~d}$. an acre and the average rent of the land leased is $£ 15 \mathrm{~s} .2 \mathrm{~d}$. an acre.

The average size of the small holdings is between 13 and 14 acres; but this is a deceptive figure, as it varies very much in different parts of the country. The average for Woreestershire is under 5 aeres, while that for Northumberland is 31 acres.

Small holdings are supplied, as the result of the Aet, in three ways. The county couneils either buy the land outright; or they lease land under the Statute for terms of years, renewable under notice; or, thirdly, in 2,984 cases applicants approved by the eounty council have obtained their land by dircet arrangement with the owners. At present each of these methorls seems to be necessary, though each las its drawbacks. Purchase of land is best from many standpoints-it nationalises a certain area, it secures 
the small holdings for ever and allows the county couneil to build cottages freely. On the other hand, it tends to raise the price of land, it involves an inercase of eounty loans and, most serious of all, it is almost impraeticable where land has a substantial building value - that is, in the neighbourhood of large towns and, in the ease of London, in the greater part of the Home Counties. Land at Limpsfield, for example, which lets at 20s. an acre or less, is worth anything up to $£ 600$ or $£ 700$ for building. It is practically impossible for the county council to buy and let to small holders at a possible rent for eultivating. But in purely rural distriets county councils usually buy outright.

The most scrious objection to statutory leasing is that the county council cannot build. 'This diffieulty is got over by purchasing or hiring for 99 ycars a small area sufficient for building eottages. But this complicates the matter and in some eases is impracticable.

Direet arrangement with the owner has the advantage of rapidity and probably of eheapness, but the disadvantages that the tenant has not permanent security of tenure and is not relieved from the bondage of feudal tradition.

In spite of their respective drawbacks, it seems impossible, and on the whole undesirable, to make any change in this matter. County council purchase and hiring are each best in eertain distriets; and direet arrangement with the owner cannot be prevented even if we wish it to be.

That there is a real demand for small holdings eannot be denied. In the first year 23,000 applicants filled in forms but a considerable number were rejected on the ground of not having capital. Numerous approved applieants have lost heart owing to delays on the part of the county councils and have gone off to the colonies. Many applicants who have been approved for $4_{2}^{\frac{1}{2}}$ years are still without land. Many more would apply for land if they did not think the Aet a dead letter.*

* In Somerset there are 1,060 approved applicants for 13,536 acres still unsatisfied ; in the Holland Division of Lineolnshire 774 for 16,000 acres. In this county the demand is deseribed as "practically unlimited" and the arrears increase year by year. The unsatisfied demand in Cambridge is 504 applicants for 5,000 acres; in Lindsey 404 applicants for 6,500 acres; in Norfolk 433 applicants for 6,191 acres ; in Cheshire 219 applicants for 7,800 acres, etc. 
Why has more not been aceomplished? Because county eouncils are mainly composed of landowning and farming classes, who, as a general rule, are hostile to progressive legislation. Very little interest is taken by country people in loeal elections; many of the scats are never contested. Landowners fear the formation of an independent class of working men and women. Farmers fear their best labourers will become small holders and prove rivals; also that wages will go up. Then there is the prohibitive price demanded for land.* Cases are known where big landowners are eo-opted on small holdings committees. They offer their land for small holdings at rents two or three times in exeess of present figures. Lack of eapital makes it often impossible for applieants to pay outgoing tenants for unexhausted improvements or to stock the small holdings. Men living

* On a rough average the County Council of Dorsetshire charges to the small holder double the rent paid by the farmer, sometimes more. All small holders pay the County Council 15 per cent. for working expenses. Heath lands in Dorsetshire have been applied for and could be reclaimed; but they should be let frec at a nominal rent for the first few years, whercas the County Council asks $£ 2$ an acre. The higher rent charged for land let as small holdings is well shown in a paper read by Mr. Lester Smith, the Oxford County land agent, before the County Land Agents' Society, in which he 'gives the following examples of increases in the rent of from 61 per cent. up to as much as 158 per cent. :

(1) Land Leased Voluntarily.

\begin{tabular}{|c|c|c|c|c|c|c|c|c|}
\hline $\begin{array}{l}\mathrm{A} . \\
\mathrm{No} \text { : }\end{array}$ & \multicolumn{3}{|c|}{$\begin{array}{c}\text { B. } \\
\text { Area. }\end{array}$} & \multicolumn{3}{|c|}{$\begin{array}{l}\text { C. } \\
\text { Old Assessment } \\
\text { Gross Estimated } \\
\text { Rental. }\end{array}$} & $\begin{array}{l}\text { D. } \\
\text { Rent paid } \\
\text { by Council's } \\
\text { Tenants. }\end{array}$ & \multirow{2}{*}{$\begin{array}{c}\text { E. } \\
\begin{array}{c}\text { Increase D } \\
\text { over C. }\end{array} \\
\begin{array}{c}\text { Per cent. } \\
\text { (61 }\end{array}\end{array}$} \\
\hline 1 & $\begin{array}{l}a . \\
16\end{array}$ & & p. & $\begin{array}{l}\mathfrak{f} \\
14\end{array}$ & s. & d. & $\begin{array}{ccc}\& & \text { s. } & \text { d. } \\
23 & 0 & 0\end{array}$ & \\
\hline 2 & 118 & 0 & 30 & 103 & 7 & 6 & $\begin{array}{lll}180 & 0 & 0\end{array}$ & 74 \\
\hline 3 & 96 & 2 & 32 & 69 & 0 & 0 & $\begin{array}{lll}110 & 10 & 0\end{array}$ & 60 \\
\hline 4 & 64 & 1 & 2 & 46 & 6 & 6 & $8510 \quad 0$ & 84 \\
\hline
\end{tabular}

(2) Land Leased Compulsorily (Parts of Large Farms).

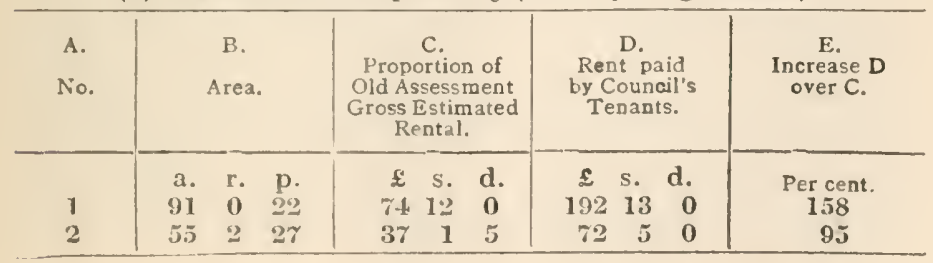


in farmers' cottages are afraid of losing their work and home if known to be applicants for small holdings. The provision of cottages is optional, not eompulsory. Councils often refuse to ereet cottages or buildings and offer applicants land two or three miles away from their home.

Roughly speaking, there are two classes of men who require small holdings - the man who has hardly any capital and who wishes at first only one or two acres which he can work at odd times while continuing as a wage-earner, and the man who has enough capital to start straight away and make his living off the land. There are plenty of these men, but at present they cannot get what they want. The Act must be strengthened, and the fundamental reform is that when the Government valuation is complete it must be made public, and be the basis for leasing and buying land by public bodies, or by the Land Commission above proposed. Innumerable instances could be given of the high price paid by county councils for land, which involved a high rent and consequent high rates for the tenant. In cases where compulsory powers have been taken to acquire land the price fixed by the Arbitrator has frequently been so high that the council has decided to drop negotiations. The cost of these proeecdings falls on the ratepayers, and naturally loeal boards hesitate about embarking on a course which may mean much legal and other expense and no land. With compulsory powers to purchase at the valuation price this obstacle would be removed.

Other amendments of the existing legislation dealing with this question are neeessary if the Acts are to be properly worked. The chief of these are in connection with the compensation of the outgoing teriant. It is obvious that he should be put to no loss in the matter; and yet some part of the payment to him (for loss of prospective profits, eost of removal, etc.) may be of no value at all to the ineoming tenant, and he should not be burdened with it in the form of extra rent. All sueh expenditure should be thrown on the small holdings aceount, as some of it is at present. The same argument applies to the sinking fund. 'There is no justiec in making small holders pay for seeuring a frechold in perpetuity to the county council. 
As regards administration, the Board of Agriculture should use to the full the powers it possesses under Section 20 of the Act, "in order to demonstrate the feasibility of the establishment of small holdings in any locality."

\section{§ 3. The Limtations of Silall Holdings.}

At this point three very scrious objections to the unlimited extension of small holdings must be faced.

(1) In the first place, it is argued that all this increased production would ereate a glut; there would be no market for the stuff, at any rate at a remuncrative price.

The answer to this is two-fold. First, it is a very long way off-so far as hardly to be worth attention at this stage. But, further, it is quite impossible that such a glut could ever be produced. A country in which agriculture became increasingly prosperous would consume more and more agrieultural produce. Two hundred years ago quite small people used dishes which required 20 yolks of eggr, a number which would be out of the purchasing power of any but the rich at the present time. The consumption of eggs and milk in Germany per head of population is double that of England; the consumption of vegetables in France is three times that of England.

In a densely populated country like ours the cause of gluts in the matter of foodstuff is not, and is never likely to be, over-production; they are due solely to defective methods of distribution. Gluts due to our chaotic marketing oceur even now, while people are starving on the one hand and foodstuff is wasted on the other. Marrows lic rotting in the country when the growers could make a profit if they sold them at a halfpenny apiece; at the same time they are priced at $6 \mathrm{~d}$. in the towns and are beyond the purse of the masses. This sort of thing is due entirely to disorganisation, and with the adoption of recommendations to be made in subscquent chapters all danger of a glut would disappear.

(2) The second objection is more forcible. For some kinds of agricultural production, and perhaps for all, large 
farming is probably more economical and more efficicnt than small farming. There is a grood deal of dispute about this and there are distinctly two schools of thought among rural reformers. It is undisputed that erops, especially cereals, cattle, sheep, ${ }^{*}$ and in the future probably beetroot, are best produeed on a large scale. It is also undisputed that fruit, vegetables and flowers, eggs and fowls, pigs, milk and dairy produce ean be very efficiently produced by small farmers.

But there is a large school of thinkers who hold that even these things ean be still better produeed on a large scale. If this be true much of the economic case for small holdings falls to the ground. This school maintains that agriculture is no exeeption to the rule obtaining throughout industry of the greater economy and efficiency of largeseale production. It brings evidence to show that, however good the produce of highly-skilled small holders may be, large farmers actually produce something still better, and that this is so eren in the ease of fruit, fowls, etc., which are the small holder's forte. At the fruit shows the finest fruit is shown by the farmers, not by the small liolders. 'The vegetables and cgoss produced by the latter are largely the result of the work of the wives, who are unpaid and the value of whose labour should be taken into account in any fair comparison.

The best size for a holding, they say, has been proved to be between 300 and 500 acres. Estates with only a few farms of more than 300 acres have suffered less from reduction in rentrolls than those where the farms were larger. But this is because few farmers have sufficient capital to support a large farm. With sufficient capital a farm of a 1,000 acres would usually give better results than if it were worked separately as two farms of 500 acres. One thousand acres, however, is probably about the maximum which one man can conveniently manage, and landowners employing experienced farmers to farm their land, instead of letting it out to tenants, have the best results when the farms do not execed 1,000 aeres in size.

* But the development of the co-operative management of herds might plaee small holders on very nearly the same footing as the large farmer even in this respeet. 
If this be so, and if, as is adnitted, the small holder will need to be equipped, financed, and organised by the State, why bother about him at all ? Why should not the State spend its money and organisation on large-scale farming straight away, cmploying more and more agricultural labour under better conditions and at higher pay? The suecess of the small holder in Denmark is attributed by this sehool entircly to the fact that they were first in the ficld and have the enormous British market close at hand.

After all, there exist in Germany a million holdings averaging 25 acres each and over a million averaging $7 \frac{1}{2}$ acres cach. The small holder ean give personal eare, which is especially important in the case of live stock; his wife and children help; there is a saving of waste, a saving of wages, a saving of management cxpenses. As against this the cost of equipment is bound to make the rent of a small holding proportionately higher; the small holder cannot regulate the labour of his horses and his men as the large farmer can do; much of his own time is wasted in jobs which could be done equally well by an unskilled labourer. The truth is that small holdings have a distinet economic advantage in some districts and under favourable conditions.

It is therefore necessary for the success of a small holder-

(i) That he should be the right man, a man of experience and method, with a knowledge of the district.

(ii) That the soil of his holding should be favourable. Heavy land, or land where pasture is of low food value, is bound to lead to failure.

(iii) That he should choose the kind of farming which needs close personal attention. Poultry, milk, and small fruit have been found the most successful; large fruit and butter should be avoided; market gardening should not be attempted at all unless close to a market; and corn growing can only be carried on suecessfully on a large farm.

(iv) That the holding should not be isolated, but in a colony where the full benefits of co-operation can be obtained. An area of at least 2,000 acres is necessary for this.

Emphasis has been laid on these points to counteract, if possible, the danger of the widespread belief that almost any 
man can makc a living on almost any piece of land. Agriculture is not an easy business; and yct people commit in eonnection with land follies which they would not dream of committing in connection with any other business. The Mayland Small Holdings experiment is a ease in point. In the month of August, 1905, Mr. Joseph Fels, who is known throughout the whole world as a shrewd business man, bought an estate situated on the IRiver Blackwater, in the parish of Mayland, in the eounty of Essex. Fired with the wholly laudable determination to use a portion of it for small holdings, he spared no expense in laying out the holdings and providing for some twenty-one men a substantial cottage each, with its own buildings and several acres of land. For lack of quite elementary business considerations the seheme broke down. In the first place there was no water at hand, and even for mixing the mortar for building pond water had to be purchased from neighbouring farms and carried to the site. The soil was heavy elay; and, as there were no roads, carting became extremely difficult in wet weather, two horses being required to move half a load. The place was so isolated that during the building the workmen had to eycle six or eight miles to and from their work. The soil was expensive to work and unsuited to market gardening. It had been devoted from time immemorial to corn-growing and had suffercd from reeent neglect; it was poisoned with weeds for gardening purposes, and, even after being repeatedly ploughed, the least neglect meant a jungle in which practically nothing but weeds could survive. Fruit-growing, which was the main business selected, is not remunerative for several years after planting, and it was found impossible for the men to make a living out of subsidiary gardening during the initial period. The men themselves were unsuitable, hecause, out of over 1,000 applieations, very ferw possessed the $£ 100$ of capital which was a eondition of acceptance, and these were mostly townsmen with little or no previous experience of the land. Even this $\mathfrak{E 1 0 0}$ proved to be far too little to provide tools, seeds, live stoek, as well as to kcep the man in food until the first scason's crops were harvested: and the income from these was so meagre that even the most thrifty of the men were left penniless in the second year. In 
spite of extraordinary generosity on the part of Mr. Fels in remitting rent and advancing money, the men could not afford to be generous to the land. Apart then from the uphill struggle which, in the most favourable cireumstances, small holders must always wage, against heavy railway charges, uneertain markets, lack of means of transit, and the general disorganisation and neglect of agriculture in England at the present time, the Mayland experiment was killed by the insufficient preparation before settlement, the inexperience of the men, the shortness of capital, bad situation, the unsuitable soil, and-in all fairness, it must be added-a run of unfavourable seasons.

The small holdings operations throughout the eountry generally must be condueted so as to avoid these numerous pitfalls and to fulfil the conditions of suceess above laid down. Otherwise a small holding, like a small beerhouse, or a seaside lodging-house, may in a brief period swallow up the savings of years and leave a man of worth stranded in middle life, broken in health and without a future. This is a real danger, and one that enthusiasts are apt to underrate. Only by reeognising it can it be averted, and a safe ladder be provided by which the small man ean climb in agriculture, as in other industries, from the position of a weekly wage-earner to one of economic independence. 


\section{CHAPTER VII.}

\section{TENANCY VERSUS OWNERSHIP}

$\mathrm{T}^{\mathrm{s}}$

HE, farmer as such has not yet figured conspicuously in our consideration of the rural problem, which has, up to the present, been preoceupied with the erying needs of the labourer, and with bringing into being that most desirable agrieultural factor the small holder. And yet it is on the farmer that rural prosperity ultimately depends. Nothing that has been urged in these pages clashes in any way with his interests, and mueh of it will indirectly strengthen his position. The minimum wage for labourers, provided he be safeguarded against the possibility of being called upon to bear at the outset an undue burden of expense, will in the long run bring to his aid the labour of men more intelligent and more reliable than any that have worked his farm hitherto. The seheme of national cottage building will revive village life and inerease the demand for his produce. The sweeping powers given to the publie to acquire land will rid the country of his worst enemy, the bad landowner, and will result in greatly inereasing his own sphere and security of tenure.* Finally, the rise of countless small holders, whom he at present views with suspicion, $\uparrow$ will surely create an imperative demand for many rural reforms which he has long desired, but desired in vain.

The interests of the farmers are, or should be, identical and co-extensive with those of the whole eountryside. The

* The tenants of State farms in Denmark enjoy extraordinary seeurity of tenure. In one case, for instance, the tenant of a $£ 1,000$ farm belonging to the township has not hesitated to build splendid stables on the farm at his own expense.

$\dagger$ This is partly due to the practice of taking a small piece out of a farm of, say, 200 acres to give to small holders, thus upsetting the whole equilibrium of the farm and damaging the farmer to a far greater extent than the mere value of the land taken. It eannot be too often urged that small holders should be as a rule grouped in large areas; the purchase of large traets of land for the purpose would not be so unpopular. 
tenure of land, the edueation of the rural population, the organisation of the market and the means of transit, the development of co-operation and credit banks, and last but not least the fairer adjustment of loeal taxation are all matters of vital moment to him. Anything that increases his present skill, anything strengthening his position in the world, is well worth doing for national reasons. Conversely he will participate-not alone, but chiefly-in the benefits accruing from those measures for the fuller development by the State of the resources of the country which are now about to be urged in the interests of all classes alike.

It may be taken for granted that the agriculture of the near future will be carried on by the two classes-i.e., the large farmers and the small holders - whose respective spheres of industry were discussed in the last chapter; and behind any consideration of what is known as the Land Question there must be some clear idea as to what is the ideal form of land tenure in each case.

In present-day polities the ideal of ownership is urged by one of the great parties in the State, beeause it is claimed that the sense of property is so deep-rooted in human nature that in practice the average man will only put his best work into what is his own. The separation of interests between landlord and tenant is bound, they say, to prevent development; the tenant is hampered by restrictive covenants and the fecling that his position is ultimately insecure, which is a direet incentive to bad farming. On the other hand, the laek of eapital is admitted to be a diffieulty in the way of small ownership. The Socialist favours for national reasons the ownership of all land by the State, and elaims that tenancy from the State can be so arranged as to give to the tenant freedom, security, and the use of capital, combining practieally all the advantages of ownership with none of its disadvantages.

Theoretically the question is the same for the farmer as for the small holder; what applies to the one applies to the other. But in practice it is not so. For small holders are being called into being, and their position ean be determined, one way or the other, without difficulty. But the tenure of land oceupied by farmers is bound to remain as at present for some 
time to come-that is to say, private individuals and not the State will continue to own the farms.* Landowners will he burdened with deatl duties and super-taxes on the one hand, while on the other hand the community will continue to take constantly larger powers of acquiring land. As this process develops the farmer will more and more tend to become the tenant of the community rather than of the landlord. But any drastic expropriation of the landlord is unlikely to take place yct, primarily for the reason that confiscation of property in land is obviously impracticable while other forms of property are allowed to escape.

The politically urgent problem is therefore the position of the small holder. From the public point of view ownership is undesirable for the reason, among others, that small owners are apt to divide their property at death, and this minute subdivision of land is recognised as a serious evil in countries where peasant proprietorship prevails. $\ddagger$

From the point of view of the small holder the case against ownership is overwhelming. He is always handicapped by want of capital, and he prefers to invest such capital as he possesses in stock, farming capital, etc., which yield a good return, rather than in land which will pay him only $2 \frac{1}{2}$ per cent. or 3 per eent. Virtually, however much capital he has, he prefers to rent a larger acreage rather than to purchase land, for the purchase of land ties him to one place and renders it difficult for him to increase his holding. A sucecssful tenant can move to a larger farm, but the chance that a small owner can buy more land adjacent to his own whenever he wants it is remote. But there is another

* Twelve per cent. of the farmers of England own their own land. In Denmark the proportion is over 80 per cent.

$\dagger$ The ease against ownership is stated very fully and clearly by EDwin Prate in his book The Transition in Agriculture, Chap. 18 and serl., which was published in 1906, just before the question became a party one with the Aet of 1907. Mr. Pratt is well known as a supporter of the Conservative Party in a general way and often writes from an extreme partisan standpoint. His strong opposition to peasant proprietorship is therefore valuable testimony from a souree certainly untainted.

$\ddagger$ La Terre, by Gure Kora, is based on the evila arising from this in France. 
reason, and one which the small holder is rather liable to forget. During the worst perind of agrieultural depression the man who was hit the hardest was the farmer who had borrowed money to buy his farm, beeause he lad the fixed interest to pay all the time; whereas the tenant farmer eould at least bring pressure to bear on his landlord to reduce the rent.

Of course, those who want ownership can get it. The Ownership Aet of 1892 was a eomplete failure. The Aet of 1907-now re-enacted by the Allotments and Small Holdings Act of 190s-has been, relatively, at any rate, a sueeess. But although purehase is possible as before, only $1 \frac{1}{4}$ per eent. in England and Wales and in England alone only just over 1 per cent. of the applieants desire to purehase their holdings.

In this ease, therefore, the course which Socialists beliere to be theoretieally correet is also that whieh is desired by the persons conecrned, not one of whom is in the least influeneed by the theory of the matter. 


\section{CHAPTER VIII.}

\section{EDUCATION.}

R. CHARLES BATHURS'T, M.P., seeretary of the Central Land Assoeiation, in a paper read before the Prevention of Destitution Conference last year, said that in many parts of the country no man under fifty was to be found who had any real skill in laying a hedge, thatching a rick, using a scythe, shearing a sheep, or milking a eow; and he pointed out that estate earpenters and woodmen were increasingly difficult to obtain, though the wages offered to such men are generally high. Not only is this undoubtedly so, but any countryman who complains of it, whether he be the squire of the village or the sixteen-shiling labourer, ascribes it directly to the existence of the village school. "Too much eddieation" has resulted in eomplete incapacity for the everyday work of the country. It is a striking comment on the work of our rural schools.

The universal demand of the ordinary village is that the boys should leave school earlier. The fact that this remedy is rejected with unanimity by all our edueationists (mostly town-bred) throws upon them the onus of finding a remedy of their own. And in the course of their search they will diseover that ignorance is not confined to the labourer, but that a large proportion of the farmers have but a rudimentary knowledge of the processes upon which their livelihood depends. Many of them do not even realise the value of education. In some distriets, at any rate, quite threequarters of the working farmers farming 100 aeres and under have had no education at all other than that given at the village school, teaching them to read, write, and do a little simple arithmetic. Among this class of farmer there is an enormous trade in compound manures, many of which are sold at two or three times their value, because the purchasers have no knowledge of what they ought to look for in the 
analysis of a manure and have never had any opportunity of acquiring it.*

The lack of opportunity to aequire sueh knowledge is serious enough in its results to-day, but to attempt to people the countryside with small holders without at the same time providing the necessary edueational opportunities would be the limit of folly. Education reform should have really preceded small holdings. But as it did not it is all the more pressing now. It should manifest itself in three distinct ways :

(1) In the elementary schools;

(2) By the establishment of practical farm schools, with land attached;

(3) In the appointment of agricultural instructors in every district under the county council.

(1) Reform should begin in the elementary sehools. This does not mean that children should begin to specialise too young; but it is quite possible to base a general education on lessons that are of special application to agrieulture. In Lindsey three afternoons a week are given to practical work, as can be done under the code. In the school garden the children learn to watch scientifically the germinating of seeds, as well as to preserve and bottle the fruits that grow there. They are taught to use the needle in the mending of sacks, they cook their own dinners and make their own

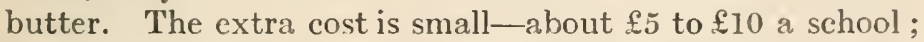
and before grudging this it is well to remember that while the average cost per child of education in this country is $67 \mathrm{~s}$.,

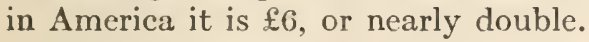

(2) A boy destined for agriculture should leave the village school not later than fourteen, but his education should not stop-adequate continuation education should be provided. Evening sehools cannot meet the demands of rural districts, though continuation day schools might be tried, which boys at work could attend two days a week on their bicycles. But what is really wanted in every district is a definite agrieultural school, not for all the children, but for the

* The possible effects of scientific research on agriculture are well illustrated by the Mendelian experiments of Professor Biffen and others at Cambridge. See Appendix .J. 
promising ones who want to go on to the land. The course at such a school should last two years and should include drawing, mathematies, bookkeeping, and the chemistry of farming, besides the practical work of ploughing, hedging, ete. These small-holders' schools exist in Denmark and provide full maintenance for the poorer children. They are supported by Government grants and local county council scholarships, they charge fees to some of the students, and they make a considerable profit per acre out of the farm land attached to the school-in the case of the Karehave School the profit is about $\mathfrak{i} 7$ per acre.

(3) The educational results that might be expected from the risits of travelling instructors in each district have been obtained in several countics, such as Lincolnshire. where such officers already cxist; and young lads who otherwise would remain in the lowest ranks of labour learn the more difficult forms of work on the farm. But with the establishment of small holdings the sphere of the county council instruetor will be enlarged and the work become immensely more important.

Two thousand acres has been suggested as the arca neessary to give groups of small holdings their best chance. The holdings should be grouped round a farm belonging to the local authority, which should be the centre of instruction, experiment and organisation. 'This is not the place to describe in detail the work that would develop round such a centre, but in all that follows on the subject of agricultural development, the idea to be borne in mind is not that of scattered individuals, each keeping a precarious foothold on his own account, but rather that of a busy group of men and women organising themselves, with the help and encouragement of the State, into definite parts of one organic whole. 


\section{CHAPTER IX.}

\section{THE ORGANISATION OF PRODUCTION.}

$\mathrm{L}$

AND is perhaps the most difficult raw material in the world. An ordinary individual, however well edueated, needs more than his own resources can furnis! in order to make the most of his land. He needs capital, he needs machinery, and he needs to be in closest touch with the manufacturing processes which prepare his products for the consumer. Above all, he needs a market, for which purpose ready means of transit and transport must be at his disposal. The smaller the holding, the more necessary is co-operation for the holder; the larger the farm, the greater the possibilities which the organisation of production affords.

\section{§1. Co-operation.}

The farmers of England are supposed to be particularly reluctant to co-operate. This is attributed partly to their innate individualism and partly to the hostility of the local tradesmen, to whom they often owe money and who naturally look askance at anything which would tend to undermine the middleman's position. The largest farmers, who should be their natural leaders, do not fecl the need of co-operation so keenly and are apt to hang back when any movement in that direction is afoot.

Whatever may be the eause, co-operation in agriculture is of quite recent growth in this country; although during the last few years it has made a marked advance, it is still far less extensive than is the case in most of the countries of the continent of Europe. 
The number* of agricultural co-operative societies abroad is :

\begin{tabular}{|c|c|c|}
\hline In Germany & & 26,576 , with $2,500,000$ members \\
\hline , Russia ... & $\ldots$ & 15,000 \\
\hline , Austria ... & $\ldots$ & 10,515 \\
\hline „Japan ... & $\ldots$ & 9,394 , with nearly 1 million members \\
\hline Italy & $\ldots$ & 8,630 \\
\hline , France... & $\ldots$ & 8,000 (about) \\
\hline Switzerland & $\ldots$ & 6,408 , with 870,731 members \\
\hline Hungary & $\ldots$ & 6,772 \\
\hline Belgium & $\ldots$ & 3,844 \\
\hline Holland... & $\ldots$ & 3,100 \\
\hline Donmark & $\ldots$ & 3,610 , with 449,480 members \\
\hline Servia ... & $\ldots$ & 1,200, with 41,193 members \\
\hline Sweden ... & $\ldots$ & 3,321 \\
\hline Finland... & $\ldots$ & 1,122 , with 181,500 members \\
\hline
\end{tabular}

In 1900, prior to the formation of the Agricultural Organisation Society, there were in England and Wales only 12 societies, with a membership of 517. In 1907, six years after the Agricultural Organisation Society had commenced its operations, the number of societies had risen to 142 , the number of members to 9,000. The last report of the Agricultural Organisation Society gives the total of affiliated societies on June 30th, 1913, as no less than $\mathbf{4 7 8}$, with a membership of 45,000 . The value of the money transactions of the various societies is estimated, for 1912, at nearly $£ 2,000,000$.

These figures, however, are not the sole indication of the capacity for common action possessed by British agriculturists, since there exists a large number of other societies worked on more or less co-operative lines-e.g., pig and cow insurance clubs, which are unregistered and are consequently outside the scope of exact enumerationt; and a still larger number of associations of one sort and another for promoting common objects, which are not co-operative in the strict sense of the term. But even if the disinclination to co-operate were still stronger in this country than it is

* Mainly from the International Institute of Agrieulture (Rome) monthly iulletins. The figures are not strictly comparable nor aceurate, being for different years and ealeulated on different bases; but in each case they appear to be the best and latest available.

$\dagger$ There are only 62 registered cattle insurance societies, but there is a large number of unregistered eow clubs and over 1,000 pig clubs, with prol,ably 50,000 members. 
alleged to be, the extraordinary achicvements of Sir Horace Plunkett and his fellow-workers in Ireland, among a usually poor and often quite illiterate peasantry, would justify any amount of optimisn as to the possibilities in the more favourable circumstances of England and Wales.*

Moreover, the county councils have now, by virtue of Section 49 of the Small Holdings and Allotments Act of 1908, power to encourage and assist credit banks and other co-operative societies which have as their object, or as one of their objects, the provision or the profitable working of small holdings or allotments; and they may, with the sanction of the Local Government Board, give grants and guarantec or make advances to such societics. There is no official information available as to how far this power has been used.

It is much to be desired that the Development Commission should make experiments in production, such as tobacco growing and beet growing, in this country. For this purpose it would be necessary for them to have more money to spend and also to possess executive authority, which is at present in the hands of the Treasury and the public department concerned.

\section{§. The Agricultural Organisation Society.}

It is probablc that the backwardness of England is much more due to differences of conditions than to differences in the : capacity for combined action of British farmers as compared with farmers abroad. When onec the number of small holdings becomes considerable it is reasonably certain

* The agricultural co-operative movement in Ireland dates only from the early 'nineties, yet in little more tlan 15 years there had been organised, through the efforts of the Irish Agricultural Society, 357 cooperative dairies, with 42,404 members and a turnover of $£ 1,726,596$; 166 agricultural societies, with 12,999 members and a turnover of $£ 87,045$; 24 poultry societies, with 6,650 members and a turnover of $£ 72,595$; there were 268 agricultural credit societies, with a membership of 17,403 and turnover of $£ 56,004$; and 67 associations with miscellaneous objects, with 6,483 members and a turnover of $\$ 310,138$. The complete trade turnover of these associations for that year was $\{2,252,380$, and the membership totalled 85,939.-Evidence by Mr. G. Russell before the Select Committee of the House of Lords on the Thrift and Credit Banks Bill, 1910. 
that co-operation will spread much more rapidly than it has done hitherto, if only because the small holder eannot achicve any considerable results without an cxtensive adoption of the policy of combined action with his fellows. The main need at the present moment is to ensure that the advantages of co-operation are clearly and adequatcly brought to the notice of agriculturists and that skilled assistance in the initial stages of the formation of societies is fortheoming. How is this need bcing met?

For some years the work of education and organisation has been carricd on chiefly by the Agricultural Organisation Socicty, with the assistance of a Government grant, * but the passing of the Development Act has caused a change in the situation. It was proposed by the Board of Agriculture and Fisheries that the administration of the large grant which the Development Commissioners are prepared to allocate for the promotion of agricultural co-operation should be placed in the hands of the Board, to be by them handed over by way of grants in aid to county councils who were willing to appoint organisers to advise the small holders in the country on the best methods of purchasing their requirements and marketing their produce. + The Development Commissioners have, however, decided that the grant should be made to the Agricultural Organisation Society, strengthened and reconstituted to meet their incrcased responsibilities to the State. The society has been reformed and registered under Section 20 of the Companies (Consolidation) Act, 1908, under licence by the Board of Trade. This section possesses certain constitutional advantages over registration under the Industrial and Provident Societies Act, under which the former society was registered when it was a purely propagandist body. Provision is made in the Memorandum and Articles of Association for the preservation as heretofore of the voluntary character of the society and for the appointment of a larger governing body, which will contain representatives

* The first grant was $\$ 1,200$, and was made from the Small Holdings Acount in 1909 .

$\rightarrow$ see l'art 1. of the Report of the Snall Holdings and Allotments Act, etc., for 1911 . 
of the Board of Agrieulture and Fisheries, the subseribers to and members of the Agrieultural Organisation Soeiety, the County Councils' Association, and the Co-operative Union.* The work of the socicty will eventually be condueted under the direction of brnach committces, whose operations will be confined to eertain areas, thereby promoting loeal effort and enlisting loeal sympathy and support.

Opposition to this new movement may be expected from two quarters. In its early stages in Ireland there was considerable opposition from the country traders, whose resentment became all the more bitter when they saw the Government purse eoming to the aid of their rivals. Now, however, the eommercial and industrial leaders in Ireland have realised that, as the Dublin Chamber of Commeree resolved, "improvements in the business methods of those who conduct the chief wealth-produeing industry of the country must inerease their consuming power," and "that this will develop the home market and so benefit the trade of Irish manufacturers and wholesale merchants."

A more foreible objection will be raised by those who look askanee at the idea of making Government grants to a private organisation. Without pretending that this is an ideal policy, it cannot be denied that the A.O.S. made out a very strong ease for it, in view of the only apparent alternative. The business of organising agricultural co-operation is highly technical and requires just the experienee whieh the offieers of the society have aequired. The administration of the work by a voluntary body is a great saving of public money. The county couneils have already as many duties as they are ready to perform ; and, moreover, the task of organisation can only be conveniently performed by a eentral body.

The present time is singularly inopportune for making proposals as to what steps should be taken to improve existing arrangements for the spread of agricultural co-opcration. The public, as eonsumers, should be much more direetly interested in the produetion of foodstuffs than the present arrangements allow, with a view, among 
other things, to the standardisation of prices. Perhaps the most workable plan, and one which would protect against the shortcomings of officialism, while giving the public the control which it is desirable it should possess, would be some sort of co-partnership between the county councils and the farmers. But until the new society has had time to get to work little good can be done by any further recommendation. It is sufficient to say that whatever future trouble the adoption of this policy may have in store there is little doubt that it marks a great step forward in the present state of rural development.

The possibilities of co-operation can be gathered from a glance at the objects of various societies, of which particulars are given in the A.O.S. reports. Those which are most specially concerned with production fall conveniently into three heads :

(1) Combined purchase of manures, food stuffs, and implements.

(2) Co-operative dairies, bacon factories, etc.

(3) Credit banks.

\section{$\S 3$. Co-operative Purchase.}

There is scarcely a country in Europe where soeieties for the purpose of combined purchase do not play an important part in agriculture. Mr. Pratt gives a full account of these in The Organisation of Agriculture, published in 1908.

In Denmark the ramifications of the co-operative purchase system extend to practically every village, and agricultural necessities, such as seeds, manures, feeding stuffs, and maehinery are obtainable everywhere at the lowest price and in the best condition. In Germany the Raiffeisen banks * take up the business of purchasing as well, thereby hindering the formation of other purchase societies; but in spite of this there were, at the end of 1912, 2,409 societies for purchase and sale, with 240,000 members.

In France a combination was first formed for the purchase of artificial manures in 1883. Others followed for seeds, eeding stuffs, and machinery, till in $\mathbf{1 8 8 6}$ was established the Syndicat Central des Agrieulteurs de France, which by

* Sce below, p. 8.5. 


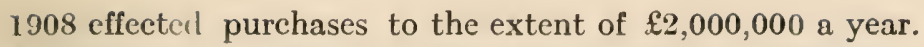
In certain commodities the various agricultural associations control the market and have brought about a decrease of nearly 50 per cent. in the price of fertilisers, while enormously increasing their use.*

In Belgium there were at the end of 19101,237 purchase societies, with a membership of 73,957; and, moreover, they invest large sums in costly machinery and let it out to their members. The total purchases in 1910 amounted to over 18,000,000 francs. In Poland the same is the case, the charge being from $2 \mathrm{~d}$. to $5 \mathrm{~d}$. for a plough, from $5 \mathrm{~d}$. to 2s. for winnowers, from 2s. to $2 \mathrm{~s}$. 6 d. for drills. The societies in Poland buy manures and seeds at moderate rates and sell to members again on credit at only $\mathbf{5}$ per cent. advance on store prices. In Italy the first syndicate was formed in 1887 on the French model and others followed quickly, but their dealings are not nearly so extensive as in France. In Holland (1,400 societies in 1913), Sweden, and Hungary the purchase movement is on the increase; and even in Switzerland, where it roused the opposition of traders through dealing in domestic articles, the number of societies was 643 in 1912, as against 521 five years before. In Finland a Central Co-operative Commercial Burcau was started in 1901, and the movement spread even to Lapland, within the Arctic circle. In Servia the business of purchasing is principally undertaken by the agricultural credit banks, which not only receive deposits and make loans to the farmers, but act as supply associations as well.

Even the briefest sketch of the operations of the cooperative movement abroad makes it clear that there are few civilised countries where so much remains to be done in that direction as in England. But the following paragraph, taken from the last published report of the Agricultural Organisation Society, shows beth the extent and the progress of the work of the trading societies here :

"Among the larger trading sucieties the Eastern Counties Farmers' Association, with a turnover of $£ 258,378$, $\dagger$ still

* The information obtainable about co-operation in France is noticeably incomplete as compared with other countries.

$+£ 278,631$ for 1912. 
takes the lead, but other societies are rapidly inereasing their trade, as the following figures will show:

\begin{tabular}{|c|c|c|}
\hline - & I9I0. & 1912. \\
\hline & $\stackrel{\&}{2}$ & $£$ \\
\hline Southern Counties Agricultural Trading Soeiety & 87,845 & 121,169 \\
\hline Carmartlien Farmers' Co-operative Society ... & 58,210 & 88,660 \\
\hline Newport (Salop) and Distriet $\Lambda$ gricultural Trading & & \\
\hline $\begin{array}{lllllll}\text { Society } & \ldots & \ldots & \ldots & \ldots & \ldots & \ldots\end{array}$ & 46,551 & $50,221 \dagger$ \\
\hline Midland Farmers' Co-operative Association . & 30,734 & 46,129 \\
\hline Clyndermen and Distriet Farmers' Association & 22,949 & 34,020 \\
\hline West Midland Farmers' Assoeiation $\ldots$... & 24,317 & 52,492 \\
\hline $\begin{array}{l}\text { Framlingham and Distriet Farmers' Co-opera- } \\
\text { tive Association... }\end{array}$ & & \\
\hline $\begin{array}{l}\text { tive Association... } \quad \cdots \\
\text { Guildford and Mid-Surrey Farmers' Agrieultural }\end{array}$ & 18,136 & 29,038 \\
\hline Co-operative Assoeiation & 13,259 & 15,069 \\
\hline
\end{tabular}

"These are only a few of the societies which might be named, as steady improvement is to be noted in almost every direction, and the smaller as well as the larger societies show a most satisfactory rate of progress.

"The largest of the above-mentioned societies, the Eastern Counties Farmers' Co-operative Association, Ltd., for example, was founded in 1904, with a membership of 158 and a share capital of $£ 1,540$. By the end of 1911 the membership had risen to 1,007 and the share eapital to $£ 7,102$.

"The first year's sales were $£ 15,400$, at a profit of $£ 86$;

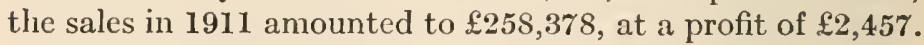
The scope of this society's activities includes agricultural machinery, sceds, manures and fertilisers, pigs, and eggs."

\section{§4. Co-operative Dairies and Factories.}

The home of the eo-operative dairy system is in Denmark. It began with the establishment of creameries, to which farmers could take their cream to be made into butter. Then, with the invention of the eream separator, the farmer sent his milk to the creamery and the skim milk was returned to him. The first co-operative dairy was opened in West

* The figures for 1912 are here substituted for those published in the 1912 report.

+ Figures for 1911. 
Jutland in 1882 ; within 20 years there was scarcely a parish in Denmark without one, and their members owned more than three-fourths of the cows in the country. The practice was for about 150 farmers in a particular district to raise, say, $£ 1,200$ by subscribing $£ 8$ each, which sum provided a dairy which could deal with the milk of 850 cows. The amount thus invested is over a million and a half of money.

This system has been copied by the farmers in the Charente district and the west coast of France.

In Holland the first co-operative dairy was set up in 1878 , but it was only after the success of the movement in Denmark that the chief development began. In 1890 there were still only 19 co-operative unions in Holland, but by 1911 there were 729 , and most of these were organised into six different leagues, which constitutes the Confederation of Dutch Co-operative Creameries. The purpose of this Confederation, which was established by Royal Decree, is to guarantee purity of buttcr and to maintain the reputation thereof in foreign markets, inspections and analyses being made and recognised trade-marks being affixed to consignments coming up to the required standard. This makes adulteration very difficult, if not impossible. The increased profits to Dutch farmers as a result of co-operative butter production, combined with preeautionary measures, are estimated at from 10 per cent. in some cases to 30 per cent. in others. The co-operative ercameries now produce thirty times as much butter as the proprictary factories.

In Belgium at the end of 1910 there were 556 co-operative dairies, with 5\%,400 members, owning 162,850 cows. In that year they effected sales to the extent of 40 million francs, an average of nearly $\mathfrak{2} s$ per member.

In IIungary the State makes large annual grants for cattle breeding and dairy farming, and has thus brought into existence $5+1$ co-operative dairies. Similarly in Austria the whole movement has been the outeome mainly of official activity, supported by numerous and liberal subsidies.

In Sweden the co-operative dairies are rapidly supplanting proprietary dairies and produce the greater portion of the total output of butter in the country, and it is significant that at the fortnightly butter shows at Gothenburg and 
Malmö they secure most of the prizes given for the first quality of butter shown. In Norway nearly all the creameries are co-operative. Finland, too, copied Denmark and used the co-opcrative movement as a set-off and response to the Russification of the country, with the result that the proprietary creameries are in a minority. Sinee the adoption of the co-operative prineiple in the Argentine and the establishment of central butter faetories there, Argentine butter obtains a priec in England second only to that of Denmark and Sweden. There were 3,488 co-operative dairies in Germany at the end of 1912, with 320,000 members, and scores of new societies were formed in 1912 alone for hydraulic works, for employment of machinery, for horse and cattle improvement, etc.

In Ireland Sir Horace Plunkett introduced co-operative dairies in 1889 , without knowing that they were already a well-cstablished institution in Denmark. At the end of 1911 there were 326 dairy societies, with a membership of 45,725. In England there is not the same scope for this form of co-operation, as it pays the English farmer bettcr, as a rule, to scnd his milk into the towns to be sold as milk, and to leave the supply of butter to his Irish, colonial, and foreign competitors. But there are outlying parts of England where farmers cannot readily dispose of their milk in this way; and, in any casc, there is an opening in England for the making of eheese. Yet the first eooperative chcese factory in England was registered only in 1903.

A thoroughly modern creamery can be fitted up at a cost of $£ 1,300$ to $£ 1,500$, most of which can be met out of subscquent profits, so that the actual call on members for cash amounts only to a few shillings a liead. There are only five dairy societies affiliated to the A.O.S. at present, and though ehecses are made by socicties in Leicestershire and by the Wiltshire Farmers, Ltd., the great bulk of the work done by the comparatively few eo-opcrative dairies in England is distributive, not productive. There is probably no form of co-operation which puts so small a financial burden on its members.

Denmark again Ied the way in the establishment of 
co-operative bacon factories when, in 1887, the German ports were closed against the pigs as a precaution against swine fever. The capital for building was obtaincd from ordinary banks on the joint guarantees of the farmers, who were therefore called upon for no cash subscription. By the rules of the society members are obliged to supply all their pigs to the factory on pain of a fine for each pig they fail to send. They subsequently receive a share of the profits proportionate to the number of pigs sent.

In England the procedure adopted has not been quite the saine, the distrihutive co-operative movement dealing rather with societies than with individual farmers. Thus the Eastern Counties Farmers' Co-operative Association, for instance, last year supplied 1,29* pigs to industrial cooperative societies and received $\mathfrak{f} 6,1826 \mathrm{~s}$. $7 \mathrm{~d}$. in return.

\section{\$5. Credit Banks.}

A credit bank is a co-operative socicty usually consisting of persons in a small way of business which obtains advances of capital on the joint security of its members and lends out to them small sums of money from time to time for productive purposes. The question that arises in the formation of such banks is whether the liability of members shall be limited or unlimited, or limited by guarantec. In a small area of, say, one parish it is best for the liability to be unlimited, but the area can be further extended if it is limited by guarantec, and in the case of a whole county it must be limited. In this country credit banks are registered under the Friendly Societies Act of 1896 and the special authority granted by the Treasury in accordance with Section 8 (5) of the Act. A society registered under that authority must have for its object the creation of funds by monthly or other subscriptions, to be lent out to, or invested for, the members of the society, or for their benefit, and must have in its rules provisions that no part of its funds shall be divided by way of profit, bonus, dividend, or otherwise among its members, and that all money lent to members shall be applied to such purpose as the society or its committee of management may approve. A credit society registered in this way cannot, however, engage in trading 
unless it forms itself into a separate society and registers anew under the Industrial and Provident Societies Aets, 1893 and 1595, which permit of the earrying on of both banking and trading, but not of unlimited liability. Trading and banking are said to be necessary complements to one another in order to provide funds for the payment of secretaries, etc., or for other reasons of convenience; and the Raiffeisen banks of Germany, of which the eredit banks in this country are imitations, earry on trading in addition to banking. 'The object of the Thrift and Credit Banks Bill, 1910, was therefore chiefly to simplify procedure rather than to confer additional powers, except in so far as it is permitted credit banks to assist in the formation of central banks for the deposit of their surplus funds.

Another Bill was introduced the same year by the President of the Board of Agriculture and Fisheries, entitled the Agricultural Credit and Insurance Societies Bill, but this also was subsequently dropped. This Bill gave to the Board power (1) to employ officers to promote the formation of agricultural credit and insurance societies; (2) to pay the costs of formation; (3) to contribute to the expenses of management of newly formed societies; (4) to appoint and pay auditors ; (5) if necessary to obtain an investigation into the affairs of the society and its winding-up and dissolution. The money was to come out of the Small Holdings Account, and the societies were to work on their own credit and not on State credit. The principle of unlimited liability was accepted, but it was proposed to use the Industrial and Provident Societies Acts with unlimited liability instead of the present limited liability, rather than to use the Friendly Societies Act under which liability is already unlimited.

The reason for the dropping of the Bill was probably the decision of the Development Commissioners to make the A.O.S. the channel for their grant instead of the Board of Agriculture and Fisheries; but whether this be so or not, the matter rests in this stage at present, exeept that the Board has come to an arrangement with some of the leading joint stock banks which have branches in rural districts whereby the managers of these branches shall assist in the formation of credit societies among small holders and 
allotment holders where the need for them is apparent. Advice is to be given to the officers of a society on matters of bookkeeping and assistanee in the audit of the annual returns free of eharge, and so long as they are satisfied that the socicty is being conducted on sound business lines managers may acept, when offered, the post of unpaid trensurer, provided it does not involve membership of the society. Interest is to be allowed to societies at the rate of 2 per cent. on the daily eredit balance on current account and at the rate of $2 \frac{1}{2}$ per cent. on a reserve fund deposit account. Facilities for loans are also to be given, but only on ordinary banking principles.

The present position cannot be considered very satisfactory, but here again much will depend on the work done by the re-constituted A.O.S.

The credit bank movement has been principally developed in Germany, where it began with the Raiffeisen banks, which are cssentially local in character and based on the principle not only of co-operation, but of unlimited liability. In that country there are 17,300 societics, of which over five-sixths are of the Raiffeisen type, with $1,670,000$ members. In Franec, where they receive subscriptions for initial expenses, and to meet the cxtra burden of bad years, there were on December 31st, 1911, 97 regional banks and 3,946 affiliated local banks, with $\mathbf{1 8 5 , 5 5 2}$ members. In Ireland, 268 societies and 17,403 members.

In Belgium there are also credit banks of the Raiffeisen type, numbering in 1913 \%38, with 21,892 agrieultural members, apart from 16 agricultural eomptoirs, which made loans amounting to three million francs in 1910. In Italy there are two kinds of village banks, (a) the Agrarian banks, which are in effect country branches of cither a people's bank or a savings bank; (b) rural banks, which have complete self-government and can themsclves utilise deposits for the purpose of making advances. In both cases the village banks can draw on the people's bank or on the savings bank for funds to lend out to their members, and in most cases the village banks are based on the Raiffeisen principle of unlimited liability. In Hungary there are 280 co-operative banks; and in Holland 582, mostly of the Raiffeisen type, 
with a central organisation at Utrecht; but in the south of Holland the Roman Catholie elergy have founded separate societies and separate banks for Roman Catholies only. In Italy at the end of 1911 there were 1,855 rural banks and agrieultural co-operative socictics of collective title. In Switzerland in 1910 there were 139 local eredit associations, with 10,024 members, ${ }^{*}$ now inereased to 195 .

In Italy there are $\mathbf{7 4 0}$ banks on the Luzzatti plan (these lend rather to the larger and medium agrieulturists); and for the rural banks proper (casse rurali) the figure is 2,003 .

There are now some 46 registered credit societies in England and Wales, with $\$ 00$ members and a total turnover

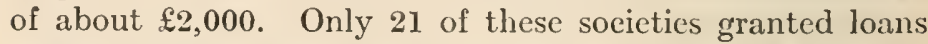
during 1912 , the total amount of the loans being $\mathfrak{£} 1,400$. In 1910 the loans aggregated $£ 1,390$, they varied from $£ 5$ to $\mathfrak{1 0}$, and averaged $£ 12$ per loan. $†$ The smallness of their progress in comparison with that of similar societies in other countries, is, of course, very marked. But it must be remembered that in Germany it took 25 years to form the first 5 eredit banks, whereas in England the A.O.S. has formed 35 in 11 years, and the movement here may be said to have now passed out of the experimental stage.

* The most rapid strides have been made in India, as is shown by India from 1901-02 to 1910-11

\begin{tabular}{|c|c|c|c|c|}
\hline & $\begin{array}{l}\text { No. of } \\
\text { Societies } \\
\text { at close of } \\
\text { year. }\end{array}$ & $\begin{array}{c}\text { No. of } \\
\text { Members. }\end{array}$ & $\begin{array}{l}\text { Loans from } \\
\text { Private } \\
\text { P'ersons. }\end{array}$ & $\begin{array}{l}\text { Share } \\
\text { Capital. }\end{array}$ \\
\hline $\begin{array}{l}1911-12 \ddagger \\
1910-11 \\
1909-10 \\
1908-09\end{array}$ & $\begin{array}{l}8,177 \\
5,321 \\
3,428 \\
1,963 \\
\end{array}$ & $\begin{array}{l}403,318 \\
305,058 \\
224,397 \\
180,338\end{array}$ & $\begin{array}{c}£ \\
1,325,824 \\
752,077 \\
432,488 \\
272,029 \\
\end{array}$ & $\begin{array}{c}£ \\
337,202 \\
210,640 \\
143,310 \\
91,408 \\
\end{array}$ \\
\hline
\end{tabular}

† Small Holdings Report, Part I., 1911.

† Cd. 70 \% 8 . 


\section{CHAPTER X.}

\section{THE ORGANISATION OF DISTRIBUTION.}

\section{§ 1. Co-operative Markfiting.}

$A^{\text {cin }}$

GRICUL'TURE carries more middlemen on its back than any other industry. If it is to flourish as it

eould were the necessaries of life brought to the vast masses of our population at a price within their purchasing power, the middlemen must be largely eliminated.

There is no more necessary artiele of food than milk. It is the only food for an infant; it means bone and muscle and brain in after life, and the consumption of milk should be universal in every household. Yet there are thousands of households in every large town where it is never seen at all, or only in a tinned form; while to find milk in a rural cottage is the exeeption rather than the rule. There is no greater tragedy in all the world than to see village ehildren literally dying for want of the milk which their fathers help to produec.

Milk is sent off to the towns to be sold at a priee often more than double what it has eost to produce. T'he high price of milk prevalent in England is due to two causes. First, the unscientifie feeding of the eows on most farms and the failure of the farmer properly to test the milking capacity

the following table, given in the Statistical Abstract relating to British (Cd. 6637, 1913) :-

\begin{tabular}{|c|c|c|c|c|}
\hline $\begin{array}{l}\text { Deposits by } \\
\text { Members. }\end{array}$ & State Aid. & Reserve. & $\begin{array}{l}\text { Loans issued } \\
\text { to members } \\
\text { and other } \\
\text { Societios. }\end{array}$ & $\begin{array}{l}\text { Loans repaid } \\
\text { to non-members } \\
\text { and other } \\
\text { Socieries. }\end{array}$ \\
\hline$\stackrel{2}{2}$ & $\stackrel{f}{f}$ & $\stackrel{f}{1}$ & $\stackrel{\mathfrak{E}}{1}$ & $\stackrel{£}{5}=5$ \\
\hline $\begin{array}{l}43: 3,346 \\
278,932\end{array}$ & 48,564 & $\begin{array}{l}64,16 \pm+ \\
36,755\end{array}$ & $\begin{array}{r}1,803,376 \\
1,131,5222\end{array}$ & $\begin{array}{l}645,565 \\
269,255\end{array}$ \\
\hline 166,201 & 48,028 & 22,041 & 692,608 & 183,825 \\
\hline 107,016 & 45,700 & 12,729 & 514,159 & 142,167 \\
\hline
\end{tabular}


of his cows, which may account for the milk of some firms actually costing four times as much to produce as that on others. 'This will tend to disappear with the fuller knowledge which a young generation of farmers will acquire from better education and the eo-operative atmosphere. Sceondly, the middlemen's profits, which average at least 100 per eent. in the case of milk in England: what the middleman sells for 14d. to $18 \mathrm{~d}$. brings the farmer only $6 \mathrm{~d}$. to $9 \mathrm{~d}$. That this enormous burden can be removed from the price is proved by the ease of Denmark, where the selling priee is only 30 per cent. above what the farmer gets, although his milk is hygienieally handled and is absolutely free from tubercular taint.

'The middleman's profit is responsible for a similarly high proportion of the selling price of other farm produce as compared with the cost of production. The following table of profits is given by Mr. Christopher Turnor :

$\begin{array}{lcccccc}\text { Mutton } & \ldots & \ldots & \ldots & \ldots & \ldots & 27 \\ \text { Beef } \ldots & \ldots & \ldots & \ldots & \ldots & \ldots & 16.1 \\ \text { Milk } \ldots & \ldots & \ldots & \ldots & \ldots & \ldots & 100-120 \\ \text { Bread } & \ldots & \ldots & \ldots & \ldots & \ldots & 54 \\ \text { Peas, bcans, } & \text { carrots, ctc. } & \ldots & \ldots & \ldots & 100-180 \\ \text { Small fruit } & \ldots & \ldots & \ldots & \ldots & \ldots & 100-150\end{array}$

It will be notieed that the burden is greatest on those articles which the small holder will mainly look to for his livelihood.

The future of small holdings lies not in the direction of self-supporting small holders, each taking in the other's washing and producing lor local consumption only, but rather in their eontributing co-operatively to supply a national and perhaps a world market. If then a glut is to be avoided incir produee must reach the public at a price wnch will ensure an enormous sale annong classes which at present cannot afford these things at all. This ran only obtain when the markets have been systematieally orgranised, when the cost of transit is cheapened, and when the producers themselves are assisted by the loeal authorities and the State to eo-operate both for their own and for the publice advantage.

The waste and overlapping that at present cxist must be 
brought to an end. Milk now comes from Scotland to Bristol, or goes from Cornwall to the North of England. In Brighton you ean buy eggs that were laid in Anglescy. There are the same number of markets in London as in the days of Stowe-i.e., eleven-although the population has inereased by $4 \frac{1}{2}$ millions since his time, or, if Greater London is included, by over 7 millions.* 'The markets themselves are aetually a hindrance rather than a help, and the waste and loss is enormous. Empty carts block the way, the space is insufficient, the prices are unprofitable, the deliveries are bad. It has been estimated that in strawberries alone $£ 100,000$ a year is lost by the Home Counties through trading with London markets. The wholesale priee of strawberries in London averages $2 \frac{1}{2} \mathrm{~d}$. per pound, whereas the retailers average $5 \mathrm{~d}$. Of $\$ 500,000$ worth of strawberries retailed in one year the growers only reccived $£ 250,000$, and many only got $2 \mathrm{~d}$. for fruit that was sold at $6 \mathrm{~d}$.

With a little organisation all thin cin be remedied and millions of money sared. Each discict should have its egg-packing and sale depôts, its fruit-storing and grading centres. The stuff must be sorted into first, second and third qualities and each quality must find its way swiftly to its appropriate market. There must be factories of byproducts, the surplus fruit must be turned into jam or dried, surplus milk must be turned into eheese. How ean English agrieulture play any part in the world of modern industry unless it sets itself to adopt the methods which are the A B.C of business and to which the agrieultural suceess of other countries is due?

Co-operation cannot be foreed, but it can be cncouraged. Iost of the neeessary reforms eould be brought about under the Derelopment Iet and no fresh legislation is yet neees-

* Population of Loudon in Stowes daysWithin the walls

130,000

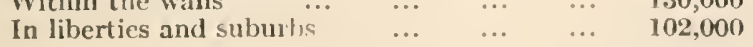

Total

232,000

Population at present time -

$\begin{array}{lllllll}\text { City } \text { of London } \ldots & \ldots & \ldots & \ldots & \ldots & 17,132\end{array}$

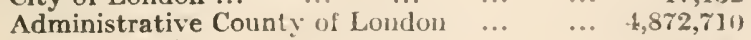

$\begin{array}{llllll}\text { Greater London... } \quad \ldots & \ldots & \ldots & \ldots & \mathbf{7 , 5 3 7 , 1 9 6}\end{array}$ 
sary. But here again England still keeps far behind the rest of the agricultural world, and here again Denmark easily takes the lcad.

The advantage of co-operative methods of sale to the countries adopting them can be clearly traced by eomparing over a course of years the export figures of Denmark to some neutral market like our own with similar figures for other countries where such methods have not been adopted. In the last $\mathbf{1 7}$ years the export of butter from Denmark to the United Kingdom has inereased enormously, while that from France has declined by more than one-half. Eggs from Denmark have multiplied threefold in that period; eggs from France have declined four-fold.* Cooperation is undoubtedly the cause of the great advance made by Denmark in comparison with France in the export of dairy produce. In France the farmer makes his own butter and takes it to the local market, where it is bought by a commission agent, who disposes of it to the wholesale merchant. The merehant then blends in a mill the produce of a whole district. The price of the butter is thus loaded with the profits of the agent, the merchant, and the cost of blending, and the farmer has to be content with a smaller return. The Denmark farmers liave no middlemen to pay; they do their own blending and reap the whole profits themselves.

In England, too, there is a marked move in the direction of co-operative sale $\dagger$ The East Anglian Farmers, Ltd. (London), returned a bonus of $2 \frac{1}{2}$ per cent. to the members of the Covent Garden branch on the produce sold during 1912. The Pershore Co-operative Fruit Market, Ltd. (Worcestershire), held its first sale as recently as June 17th, 1909, yet for the year 1911 it showed a turnover of $£ 10,799$, paid 5 per cent. to the shareholders on capital invested, 25 per cent. to a reserve fund, 5 per cent. to employees, and a bonus equal to $1 \frac{1}{4}$ per eent. of the profits on the value of the produce sold. The Wiltshire Farmers, Ltd., had a turnover of $£ 66,000$ in the first half of 1912 ; and during that year seven new dairy and egg societies were registered.

* See Appendix L.

$\dagger$ See Annual Reports of A.O.S. 
In the year 1911 the Framlingham (Suffolk) District Co-operative Society, founded by the A.O.S. in 1903, sold for its members $3,922,000$ eggs for $£ 16,000$.

In the eastern division alone the A.O.S. reports for 1912 a sale of eggs by the affiliated societies to the number of $6,768,944$; thirty-two societies in the country sold $11,000,000$ between them. The total value of eggs and poultry sold by affiliated and unaffiliated societics during that year is cstimated at $£ 50,000$. Societies have now been formed in every county in Wales except Radnor.

\section{§2. The Nationalisation of Railways.}

The high railway freights in England are more disastrous to agriculture than to any other industry, and there is probably no one reform which could affect the whole of rural life so beneficially as the reform in our railway system. The average cost in this country of sending a ton of goods one hundred miles is nearly double that in Germany or Austria-Hungary, is more than double that in Holland, and is more than three times that in the United States of America. And this British average includes the hundreds of millions of tons of imported goods which are carried at far lower rates than are available to the British trader.*

The rate of a ton of apples from Normandy to London, or even from California to London is $15 \mathrm{~s}$. $8 \mathrm{~d}$.; for a ton of English apples from Folkestone to London it is $24 \mathrm{~s} .1 \mathrm{~d}$. The rates for walnuts, apples, plums, pears, etc., from Flushing (Holland) to London via Queenborough is 12s. $6 \mathrm{~d}$. a ton, as against 25s. from Queenborough itself. At a discussion in the Norfolk Chamber of Agriculture on May 21st, 1905 , a member stated that he was charged at a rate of $93 \mathrm{~s}$. a ton for sending apples $32 \frac{1}{2}$ miles.

Foreign dead meat comes to London from Liverpool for 25s. per ton, British meat for 40 s.

* The figures that follow are taken partly from the evidence given before the Railway Commission and the Agrieultural Commission of 1905, partly from Railivay Nationalisation, by W. CunNinghas, 1906, and from The Nationalisation of Railways, by EMrL Davies, 1911. The rates are always being altered and are unlikely to be accurate at this moment, but the alteration is usually in an upward direction. 
A ton of eggs from County Galway to London, Birmingham, or Nottingham would cost 90s. 10d., while a ton of eggs to the same three places from any part of Denmark would cost 24s., from Russia 22s., from Normandy or Brittany 16s. 8d. Mr. A. W. Munro stated on behalf of the Board of Agriculture before the Agricultural Commission that if rates in England were equalised with forcign rates it would eonsiderably inerease the cgeg industry in this eountry. IIe also handed in the following table :

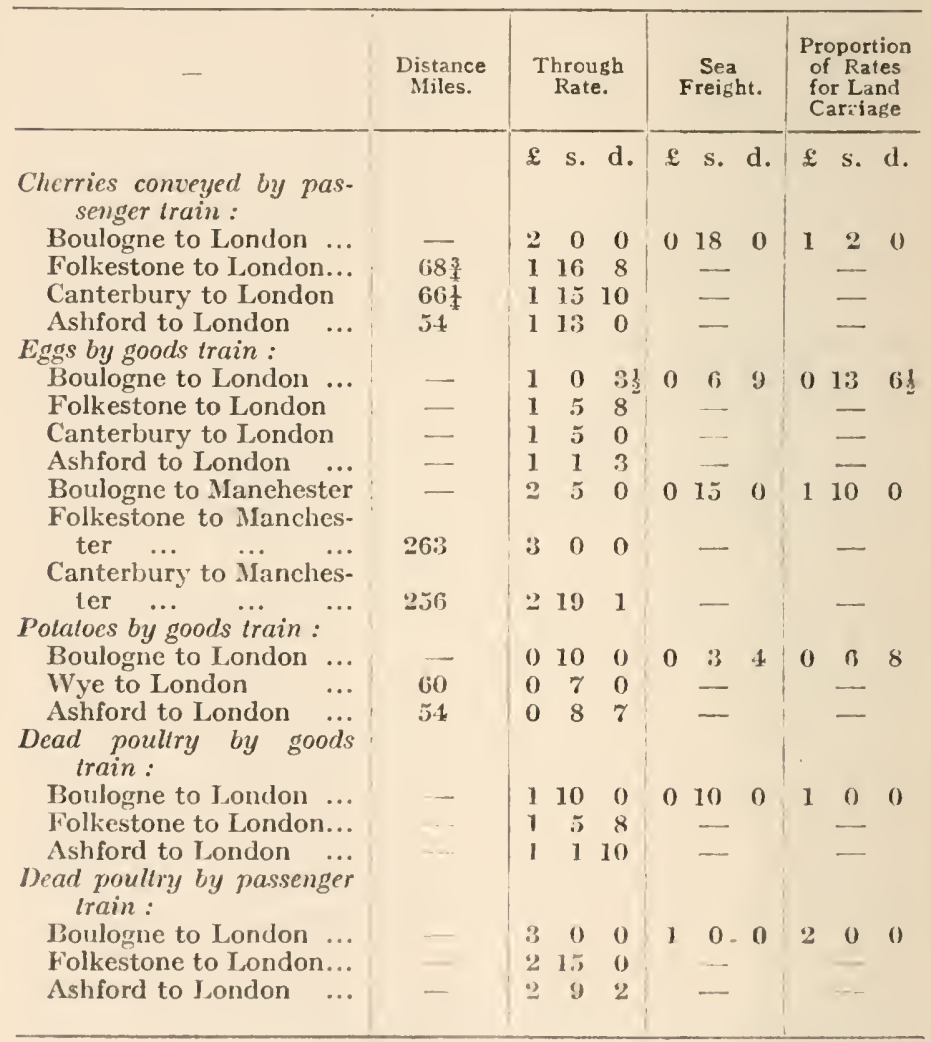

The preference to foreign growers of grain varies from 5 to 25 per eent., and Mr. T. W. Barclay, M.P., said some time ago at a traders' conference, "I may bring the result 
home to the minds of landlords and farmers by stating that the differenee of rates charged between foreign and home grain is equal to a tax of 5s. per acre against the home growers." The rates for fruit have been estimated to give a bounty of $30 \mathrm{~s}$. per acre against the home grower.

It was given in evidenee before the last Royal Commission on Railways that the farmers of the Midlands had to pay $£ 400,000$ on $£ 1,000,000$ of produee. 'The higher rates in themselves would kill agrieulture by raising the price to the consumer and so limiting the consumption; but, aceompanied as they are by lower rates to the foreigner, they operate also to spoil the ehanees of the British agrieulturist in the market as it exists.

The rates from the prineipal ports are mueh lower than from other places, which injures agriculture, as the port is not an agricultural eentre. Taking Driffeld as a good agricultural eentre in the north, and comparing the rates from there with the rates from IHull, we get the following results :

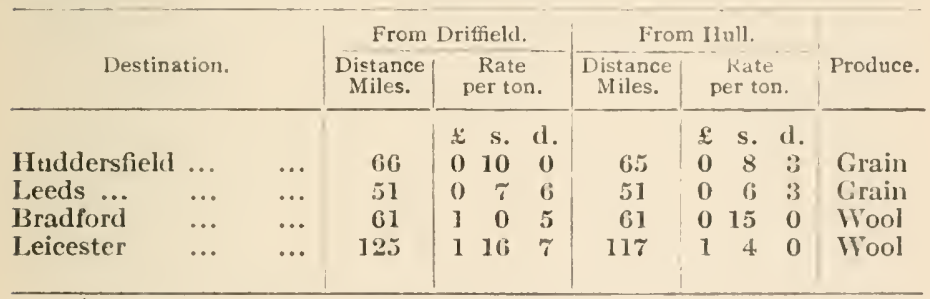

'Tlie wool rate from Hull to Leicester works out at $\mathrm{l} \cdot 4 \mathrm{~s} 8 \mathrm{~d}$. per ton per mile; but from Selby to Bradford it works out at 5.419d. per ton per mile. The same differenee oceurs in the ease of potatoes and roots, which cost only $1.31 \mathrm{Sd}$. per ton per mile from Hull to Manchester, but $3 \cdot 333 \mathrm{~d}$. per ton per mile from Goole to Doncaster.

The most extraordinary instanee of preference to the foreigner was given by Mr. Chiozza Moncy in the House of Commons on February 11th, 1908, when he quoted the ease of 100 tons of potatoes, which went from Dundee to New York and back again to Liverpool for $£ 5$ less than it would have eost to take them from Dundee to Liverpool direet.

The Agrienltural Commission reported in May, 1906, as 
follows: "The total imports into Great Britain in 1903 werc

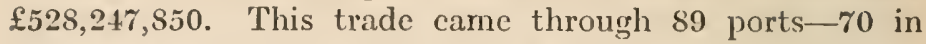
England and 19 in Scotland. But about 93 per cent. of this trade came through 15 ports as under :

\begin{tabular}{|c|c|c|c|c|c|}
\hline & & & & \\
\hline & & $\cdots$ & ... & $\cdots$ & $137, \mathbf{1 3 2 , 0 8 8}$ \\
\hline \multicolumn{2}{|c|}{$\begin{array}{l}\text { London imported } \\
\text { Liverpool }\end{array}$} & $\ldots$ & $\ldots$ & $\ldots$ & $129,000,840$ \\
\hline Hull & ", & $\therefore$ & $\cdots$ & $\ldots$ & $32,601,063$ \\
\hline Manchester & , & ... & $\ldots$ & $\ldots$ & $20,279,255$ \\
\hline Harwich & , & ... & $\ldots$ & $\ldots$ & $19,391,913$ \\
\hline Southampton & $"$, & $\cdots$ & $\ldots$ & $\ldots$ & $15,740,195$ \\
\hline Glasgow & ," & $\ldots$ & $\ldots$ & $\ldots$ & $14,4,08,658$ \\
\hline Leith & ," & $\ldots$ & $\ldots$ & $\ldots$ & $13,787,191$ \\
\hline Bristol & :" & $\ldots$ & $\ldots$ & $\ldots$ & $12,751,022$ \\
\hline Newhaven & ., & $\ldots$ & $\ldots$ & $\ldots$ & $11,349,840$ \\
\hline Folkestone & , , & $\ldots$ & $\ldots$ & ... & $11,053,872$ \\
\hline Grimsby & ., & $\ldots$ & $\ldots$ & $\ldots$ & $10,148,431$ \\
\hline Newcastle & , & $\ldots$ & $\ldots$ & $\ldots$ & $10,051,602$ \\
\hline Dover & ,. & $\ldots$ & $\ldots$ & $\ldots$ & $8,272,691$ \\
\hline Goole & , & $\ldots$ & $\ldots$ & $\ldots$ & $6,391,159$ \\
\hline & & & & & \\
\hline
\end{tabular}

"This shows that imports go in full train loads and home produce in small quantities, and the railways argue that the home traders are only entitled to similar rates under similar circumstances."

The circumstances of the home traders are not and never can be similar; the most that co-operation can do for agriculture is to minimise the enormous disadvantages which the British agrieulturist labours under as a result of the argument of the railways to which the Commission referred. It may be a good argument, it may be the only possible argument from the railways' point of vicw. But this only emphasises the folly of leaving so vital a factor of national prosperity as the means of transit undoubtedly is in any other hands than those of the nation itself.

The grievance of the agriculturist is made greater by the fact that rates are not only high, but almost farcically complicated. There are ozer 200,000,000 different rates in operation in this country. In Prussia any trader can get the ordinary and special rates, and work out the cost of carriage of any load to any part of the empire in two or three minutes with the aid of a book issued by the State for 6d.; the Government keeps the preferential rate 
up its sleeve for special oceasions. In England it is practieally impossible to find out what the rates are. The average station master simply does not know. In giving evidenee on behalf of the Great Western Railway before the Agricultural Commission in $1905 \mathrm{Mr}$. Hennell, assistant goods manager, was asked, "On what terms eould a single farmer put three tons of hay on a truck to Birmingham ?" He answered, "You will understand that I eannot answer that, as I have not read all the $30,000,000$ rates our Company have got." Before the same Commission witness after witness representing agriculture eomplained that farmers could neither understand nor even in many cases ascertain the rates. Mr. Bullen, representing the Midland Counties Agricultural Traders' Association, went so far as to say that a simple universal system of rates (such as prevails in Germany) would save farmers from $2 \mathrm{~s}$. to $5 \mathrm{~s}$. an aere on their arable land.

Sinee 1839, when Mr. Gladstone brought in a Bill to revise railway rates, there have been at least twelve Committees or Commissions bearing upon the subject, and the evidence has been overwhelming of the hindrance to trade. In 1893 the House of Commons passed a resolution that the railway rates, charges, and conditions of traffie were most prejudicial to the agrieultural and eeonomical interests of the eountry, and reeommending the Government to deal promptly and effeetively with the subject. But the hindrance still exists; the British rates are still the highest in Europe, although the eireumstances are more favourable to low rates here than in many other countries.

The experienee of nearly a eentury has amply proved the powerlessness of Parliament to deal with the question without taking over the responsibility for the finanee and management of the railway system. To quote an extreme case, it might often happen that a loss over one transaction, or even a loss over one streteh of railroad, would be a gain to the nation as a whole. Some tine ago the German nation earried hops from Bavaria to Hamburg free, in order to enable them, if possible, to capture our market, the dead loss to the railway system being more than eounterbalanced by the profit on other pages of the national ledger. It is 
unreasonable to expect private railway companies to suffer such losses ; it is impossible to make the most of our transit system while it is worked for profit and not for use, by different companies, with different boards, different methods, and different rates of carriage. The nationalisation of the railways must therefore be plaeed in the very forefront of agricultural reform.*

\section{\$:, A State Motor Service.}

In the meanwhile it is high time that the State made some experiments of its own in transit other than railway transit. The great businesses are now using the roads for the purposes of motor eonveyance, the G.P.O. has its motor vans, and there would be an enormous saving both of time and expense if a similarly speedy and simple means of transport could be organised in agricultural distriets, more especially for fruit and stuff that deteriorates with time.

A country motor service is needed not for produce only, but for passengers as well. Going to market is very difficult in rural England; and village life as a whole is unnecessarily isolated. The farmer farms in a corner and is consequently ignorant of agricultural movements; the labourer fossilises body and soul and is a political danger to the community. In parts of Germany the mails are taken from the village post office in motor brakes that al $\circ$ carry passengers, and twice a day, at least, the remotest villages in the Bavarian Highlands are brought into touch with one another and with the country town. For a few pence the labourer's wife rides to market with her basket on her arm and the earpenter goes to put in for a job in the neighbouring village. Loeal entertainments and educational facilities can thus reach a larger puhlic; the point of view of the villager is broadened and his sphere of activity enlarged, not financially alone, but socially and morally as well. Village life would be far healthier if the community would once and for all break down the barrier of prejudice that impedes collective enterprise, and seriously set itself to develop the possibilities of country life.

* Mr. Balfour Browne, Í.C., in a paper read before the London Chamber of Commeree, February 10th, 1897, said : "I an not exaggerating when I say that the Agricultural Question ... is nothing else but a question of railway rates." 


\section{CHAPTER XI.}

GAME,

\section{§ 1. Tie Problem.}

$7 \mathrm{HE}$ use of land by private individuals for the purpose of preserving game when England is under-culti1 vated and the bulk of the population is landless
represents to many people the acme of wastc and wickedness. To abolish the Game Laws and the "landed " class that administers them, to restore to the people the right both to till the soil and to enjoy the outdoor pleasures of country life, to turn our countryside from the pleasure-ground of the rich to the treasure house of the ordinary citizen, these are aims which figure largely among the stock-in-trade of a certain type of political orator, and appeal, as indeed it is right they should appeal, to the imagination of a proletariat that feels itself disinherited. The only pity is that those aims are usually lost in generalities, and that their advance is marked too often by ignorance of the main factors of the problem, which must be grasped and taken into account in any serious attempt to formulate a policy for the land.

Three considerations must be urged not as an argument in favour of private game-preserving, but in order to make clear that many of the natural features which are incidental to game-preserving must be preserved for their own sake, and that the displacement of labour and ralues insolved in its abolition must be provided for in the new order of things. For a new order is imperatively necessary, in view of the damage and waste to the countryside and the eruel privation to the individual, due to the callous stupidity of a system which hands over the land of England as a plaything to the irresponsible few.

In the first place it must be recognised that, even from the point of view of agriculture, it is a good thing that there. should exist all over the country those spots of wild beauty 
where the pheasant is bred and the fox comes to make his home. Woodland and cover and copse and spinney, which to the town-bred statistician represent so much wasted possibility of eultivation, influence the climate of the surrounding country and harbour the life which preys on agricultural pests. Here live hawks, and the owl, archenemy of mice; hence come showers and dew. These places could not be ploughed up and intensively cultivated without materially altering the climate and destroying the balanee of n:tural life. Even the game itself is not always injurious. The real damage is done by hares and rabbits, rooks and pigeons. Pheasants are a nuisance in the case of autumnsown corn, but at other times do no hurt. Partridges are quite harmless. They never scek out grain newly sown like the rooks. It is the slugs, grubs, worms and inseets they are seeking, the bits of weeds and their seeds, aphides, earwigs, and ants' eggs. The more the soil is worked, as by harrows, the more food they are able to find, and the more good they do by destroying inseets and grubs that injure delicate roots.

In the second place the fact must be faced that any drastic interference with game-preserving would seriously affect the livelihood of our village population. The partridge brings the peasant many a good shilling for finding nests, the farmer sells stuff for the pheasants. Besides the keepers and underkeepers and persons regularly employed in the task of game-preserving, there are the ordinary villagers who turn out for many a day's enjoyment when the shooting season begins, and earn good wages as beaters and a hearty lunch into the bargain.

About 35 per cent. of the expense of keeping up a grouse moor consists of the wages of a permanent staff ; for every $£ 1$ of rent another $15 \mathrm{~s}$. or $£ 1$ is spent in the neighbourhood in wages of villagers, hiring, carting, etc.* If these estimates be correct, the abolition of grouse-shooting, for instance, would involve enormous displacement of labour. The approximate gross rental value of grouse moors in England and Scotland is about $£ 1,270,000$ annually; the wages bill 1912.

* The Grouse in Health and Disease; see Preface by Lord Lovat, 
is therefore about $£ 444,500$, and an additional sum of about $£ 1,000,000$ is spent in the grouse districts every year for purposes of the sport.

A third consideration is the fact that large tracts of country are actually worth more for sporting purposes than they are, or ever could be, for purposes of agriculture. It is true 5,500 square miles in Seotland alone is reserved for the pleasures of the rich. But it is also true that a large proportion of this is probably useless for anything else but a deer forest, and in the selection of waste land for cultivation good grouse ground is the last that would be chosen by practical agriculturists. The sporting rents of grouse moors average between five and ten times the grazing rents, and are higher than anything that could ever be paid for them for any other purpose.

The most frequently quoted example of the game evil is afforded by the deer forests of Scotland. In the crofting counties they have almost doubled their area in the last thirty years.* The result has been a depopulation of the rural districts, a most glaring instance of which is Couric, where the extension of shooting acres was accountable, during the last intercensal period, $\uparrow$ for one of the biggest decreases, farms being thrown out of cultivation and many men deprived of the hope of subsistence on their native soil. The extension is still continuing. But it is good to find from the latest issued report of the Scottish Congested Districts Board (now merged into the new Scottish Department of Agriculture) that during the year ended March 31st, 1912, portions of deer forest on the estates of the Countess of Cromartic, the Duke of Sutherland, Mr. W. E. Gilmour, and others were assigned for the extension of crofter holdings, a reclamation from sport to agriculture of over 3,000 acres. But this is but a tiny fraction of the $3,250,000$ acres of Seottish land set aside for sport.

In England game-preserving injures agriculture in three distinct ways. First, too much is spent on it by landowners of limited means, who let their farms suffer rather than

* Parliamentary Paper, 220, 1908.

$\dagger$ Scottish Census Returns, 1911. 
their shooting. Then again too much game is preserved for the land in many districts and the damage done to the farming is immense, reducing the value of farms in some cases by quite $4 \mathrm{~s}$. an acre.* The economic loss is enormous, because shooting rarely commands an average of more than 2s. an acre all round. 'This damage is done not only by the game itself, but by the fact that all other interests are subordinated to the game. The keeper kills everything that will hurt his young birds and so deprives the neighbourhood of its natural scarengers, who would keep under vermin and pests. Thirdly, the individual farmer often suffers in uncertainty and discouragement, a damage for which nothing can compensate him. Mr. Turnor says : "I have been over farms on which not only a large proportion of the root crop, but every single swede and mangold had been damaged by hares. I have heard landowners, men who ought to know better, say of such-and-such a farm that it was only fit to rear game. There are very few farms of which this could be in any wise true, but there are many which are not fertile enough to support a big head of game as wcll as to produce paying crops."

As a matter of fact, the compensation, when paid, is generally inadequate. The damage done by fifty pcople galloping orer a ficld of wheat in wet weather is irreparable, yet it cannot be fairly estimated or charged for ; and, as a mattcr of fact, it does not of ten occur, as foxhunting people are more careful than they used to be and the farmer is often more frightened than hurt. But the loss of poultry owing to foxes is a serious item in the farmer's budget, and as a rule hunts do not pay adequate compensation. Forty or sixty head of poultry are stolen in a night; they may be pedigrec birds, but the breeder is lucky if a $£ 5$ note is paid in settlement of his claim. As for the "reasonable compensation " which the farmer is supposed to receive under the Land Holdings Act of 1907 when he holds land adjacent to coverts, that applies only to pheasants. The farmer's chicf damage from large coverts, however, arises from the rabbits, which pour out in hundreds on to his land, doing

* Christophla 'Tunnor, Land Problcms, p. 17. 
damage for which the Act secures him no compensation. The small man suffers even more than the large farmer, because he is less able to take advantage of such modieum of protection as the Ground Game Aet affords by employing a rabbit catcher to snare the intruders.

\section{\$2. The Abolition of the Game Laws.}

This state of things is intolerable and must be swept away. The renedy often suggested is the abolition of the Game Laws. What does this involve?

The laws affecting game fall naturally into three categories:

(i) First there are the laws making a close time for game. There is no suggestion for repealing these, which apply to fish as well as to game; and where the laws do not apply custom is often strong, as in the case of foxes.

(ii) Then there are the penal laws, which are very severe on persons who unlawfully take game belonging to other people; and game includes the eggs of some egg-laying species. As much as fourteen years' penal servitude may be awarded to three or more persons unlawfully entering land armed with any gun, erossbow, or bludgeon for the purpose of taking game. Some such laws must exist if game is to be preserved at all. The essence of the matter is that there is no private property in wild birds and beasts. A robin, or rook, or pigeon, or fox, or rat eannot be stolen - they do not belong to the person on whose land they live; they are free, and belong, like the lords of ereation, to themselves. The hunter who captures them (in a lawful manner, and in some cases outside the elose time) becomes the owner. If game is to be preserved at all, therefore, there must be special legislation. In the case of ground game the right to kill cannot, under any law, be disassociated from oecupation. In other words, the farmer has the statutory right, out of which he cannot legally contract, to kill ground game. For other game it is the owner of the land who has the right to kill, which he may lease to the oceupier or anyone clse. Trespass in pursuit of game is made a criminal offenee; trespass at night in partics in pursuit of game is subject to extremely severe penalties; the unlawful possession of gamc and the sale of game by unlicensed persons are also punishable. 
The repeal of these laws would make the difference that poaching, now ferociously punishable, and trespass in search of conies, now a constant souree of fine by the rural beneh, would become simple trespass, which is not eriminal, but only exposes the trespasser to action for damages. The kecper, if such continued to exist, would ask the name and address of the poacher and politcly require him to leave. The man, when sued, would only be sued for damages to the herbage, not for the game itself. It is obvious then that the abolition of the Game Laws would involve the abolition of game-preserving, and, practically speaking, in most cases the abolition of game. Shooting as a pastime would cease.

The question arises whether this is, after all, desirable. What is wanted is not to abolish sport, but to prevent its clashing with the public interest, and, if possible, to enlarge the sphere of its enjoyment. If the rccommendations made above in Chapter $V$. were adopted the question would practically solve itself. Were it open to any four people to complain that land was nisused and to demand an inquiry, landowners would be obliged to keep their sporting proelivities within such limits as not to lay themselves open to the risk of having their land bought compulsorily and losing their sport altogether. Such as remained to them would not interfere with the interests of the locality ; while on the tracts of land which would increasingly fall into public hands, parts of which could be afforested, sport in many forms could be organised for a wider public and be brought within the enjoyment of many to whom it is now an injury and an offenec. The man who devotes wealth and cnergy to the rearing of hand-fed pheasants is useless, dangerous, and ought to be abolished. The man who ean spend a holiday in natural sport is a souree of health to the community and ought to be encouraged.

(iii) The third eategory of Game Laws is the system of liecnees imposed on persons who have lawfully to do with game. And as long as the Game Laws are not abolished these will remain. Henee the demand that they should be increased and amplified, and that to the other burdens which it is now rightly sought to put upon the rich there should be added a heavy tax on game-preserving. 


\section{\$3. Tax on Game-preserving.}

Several methods have been suggested. A tax on land devoted to game is not so simple as it appears at the first blush. We do not want to destroy the coppices of the Home Counties; we must not penalise the devotion of waste lana to the production of timber, with game as an accessory. Grouse moors may as well be used for grouse, sinee they must be generally uscless for anything else, and finally the head of game reared and the damage done to agriculture bear no dircet and often an inverse ratio to the acreage occupied therewith.

A tax might be levied on land exceeding a certain acreage in one parish devoted to sport, with the object of preventing land being kept uncultivated. Exceptions would have to be made either for certain counties or for land covered with heather or for land used as grouse moors-on these the charge should be very much lower. In any case it would be difficult to impose such a tax with complete fairness.

A progressive tax might be imposed on gamekeepers and other persons (if any) engaged wholly or mainly for, or in connection with, rearing and preserving game. The present tax is 15 s. for a malc servant and $\mathfrak{2} 2$ for licence to shoot. A super-tax scale would bc, say, $£ 3$ for the first gamekeeper, $£ 410 \mathrm{~s}$. for the second, $£ 6$ 15s. for the third, $£ 10$ 2s. $6 \mathrm{~d}$. for the fourth, and so on. The chief objection to this proposal is that a tax on employment would not be popular in rural districts.

Probably the most effective form of tax would be that suggested by Mr. R. A. Bray, L.C.C., viz., a tax on the annual bag, to be paid in aid of rates in every parish. Every person who shoots keeps a game-book, or other humbler record of his suecess, and the size of the bag is a matter of local and oceasionally of national emulation. The bag of all large game-preservers is known in the parish to a nicety, and if steps are taken to publish the returns locally cvasion would be difficult. It is usually estimated that every pheasant killed costs $£ 1$. A tax of 2 s. a head, or 10 per cent., could easily be levied on each game-bird killed. To aroid collecting small sums, and also to avoid taxing small people, 
the tax might be remitted on the first hundred head of game shot.

There is no objection to such a tax on the score of its burden. The people who shoot can quite well afford to pay, and if it is sought to tax luxuries a Chancellor of the Exchequer could find no fairer prey. But there is a very serious theoretical objection to the multiplication of indirect taxes. However heary the tax on game-preserving. it would produce a small sum at best, it. would not affect to any extent the amount of game-preserving, and could only slightly alter the personnel of the game-preserver's. The sound tax is the direct tax on income, which should be more heavily graduated; and if the super-tax were eonsiderably increased it would fall on the same people as a game tax, and a good many more of the same kidney besides. Meanwhile the evils of grame-preserving should be dealt with not indireetly by taxation, but directly by giving to the local authority the power to put a stop to them.*

* It las been suggested that the local authority should have power to suspend the Game Laws. This is, of course, impossible. You cannot have criminal law different in different districts; they must be abolished everywhere or nowhere. 


\section{CHAPTER XII.}

\section{AFFORESTATION.}

$\mathbf{N}$ a previous chapter afforestation was mentioned as one of the means which the State should employ to develop the national reserves of the eountry. In fact, if afforestation is to be undertaken at all it must be done by the State. Private individuals eamnot undertake it. It must extend over a larger area than the individual controls, and it is not immediately remunerative, so that few individuals find it worth while. So little, indeed, has forestry been in the minds of English people that praetieally nothing is known about it in this country and mucl that has been loosely spoken about it is wide of the mark.

Quite recently, in 1909, a Royal Commission issued a Report on the subject, ${ }^{*}$ eontaining the unanimous reeommendation of 19 Commissioners of all political parties, all of whom were impressed with the need of State action. From this report it appears that there is less forestry in this country than anywhere in Europe, ineluding Belgium where the population is much denser than ours. The pereentage of land covered with trees in the various countries is as followik:

$\begin{array}{llllllllll}\text { Servia } & \ldots & \ldots & \ldots & 48 & \text { Belgium } & \ldots & \ldots & \ldots & 17 \cdot 3 \\ \text { Russia } & \ldots & \ldots & \ldots & 42 & \text { France } & \ldots & \ldots & \ldots & 17 \\ \text { Sweden } & \ldots & \ldots & \ldots & 35 & \text { England } & \ldots & \ldots & \ldots & 5 \cdot 3 \\ \text { Hungary } & \ldots & \ldots & \ldots & 35 & \text { Scotland } & \ldots & \ldots & \ldots & 4 \cdot 6 \\ \text { Austria } & \ldots & \ldots & \ldots & 32 \cdot 6 & \text { Wales } & \ldots & \ldots & \ldots & 3 \cdot 9 \\ \text { Germany } & \ldots & \ldots & \ldots & 25 \cdot 9 & \text { Ireland } & \ldots & \ldots & \ldots & 1 \cdot 5\end{array}$

In 1907 we imported $8,313,957$ loads of timber, costing $£ 20,127,943$, from other countries of a elimate similar to our own. This could well have been grown on $9,000,000$ aeres of land at home, and by a curious coineidence the inquiries of

* Second Report of the Roval Commission on Coast Erosion, Reelamation of 'Tidal Lands, and Afforestation in the United Kingdom. Cd. 4460. 1909. 
the Commission into the amount of land arailable for afforestation revealed the fact that there exists in England six million acres, in Scotland two and a half million acres, and in Ireland half a million aeres, exactly 9,000,000 acres in all, which are adapted for afforestation, but which at present produce praetically nothing and employ hardly any labour at all. The Commission therefore recommended the purchase of this land gradually at the rate of 150,000 aeres a year, as a remunerative seheme of seientifie forestry, which would ineidentally help to solve the unemployment question as well. They point out that the investment of $£ 13$ 6s. 8d. an acre, with interest and managenent expenses in addition, and no return for at least 40 years, is not an investment for the individual, but may well be worth the while of the State, especially if the eventual result is to pay £3 $16 \mathrm{~s}$. 8d. an acre yearly on the whole outlay from the forty-first to the cighticth year of the statutory period of repayment.

Whether or not the State will adopt such a scheme, it is quite elear that as the eommunity aequires more land a certain amount of it would be put to the best use by afforestation. If this were undertaken under the sujpervision of a well-cquipped forestry department of the Board of Agrieulture it would not prove an expensive matter. A great deal of common land in Surrey, for instance, is highly suitable for the purpose and could be afforested without licavy outlay and without risk. The present value of the trees that are now growing on it is low and would involve no risk to the purehaser. The sporting value could be recouped if desired by letting the sporting rights; and, apart from these two things, $\mathfrak{l}_{2} 10 \mathrm{~s}$. per acre eapital value is almost all on which interest would have to be provided until the newly planted woods began to yicld. The ralue of the land for planting would be nearly doubled if temporary feneing were permitted against rabbits direetly the property was aequired by the State. Legitimate rights (which are very little exereised) would not be interfered with, while the provision of extra winter work would prove most popular.

Afforestation is not a panacea, but it is a necessary part of the seheme of rural development. It improves the value 
of surrounding land, it provides employment, it reclaims tracts which are nearly useless at present, and it gives the community control of sporting arcas which it can, if it will, place at the disposal of any who cannot afford the highly preserved and expensive sport of the richer elasses. Moreover, it will preserve for England the woods which are in danger of disappearing under the neglect and ignoranee of their present owners. Discase is rife, notably among the beeches and the larehes; planting is being discontinued as the least immediately remunerative work of estate management. Without State action our woods are doomed; with it they may gradually grow again into being, bringing added wealth to the people and forest beaty to the countryside. 


\section{CHAPTER XIII.}

\section{RATES**}

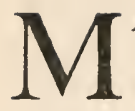

ANY of the most thorny problems of rural development have now been dealt with. But one portion, perhaps the most important portion, of the ground remains uncovered. No practical politician can approach the rural problem without being immediately confronted with a universal outery against the rates.

After all, rural rates are at present lower than they used to be a hundred years ago. 'The extra cost of education, sanitation, etc., has been more than compensated for by the abolition of the Church rate and the decrease in the poor rate. "In 1803 the average rates throughout the then entirely rural county of Sussex were $8 \mathrm{~s}$. $7 \frac{1}{2} \mathrm{~d}$. in the $\mathcal{f}$, and the average throughout the equally rural county of Monmouth was $7 \mathrm{~s} .11 \frac{1}{4} \mathrm{~d}$. in the $f$. These were not eren the most highly rated counties. Throughout all Carmarthenshire the average rate was 12s. 9d. in the $\mathfrak{f}$, and throughout all Pembrokeshire it was 11s. $8 \frac{1}{2} \mathrm{~d}$. in the $f^{\prime . "} \dagger$ In fact, during the last 20 years the rates in rural districts have been lower than at any previous period for more than a century past, and the fall has been greatest in the agricultural districts. Yet here it is that the outcry is greatest, or, at least, has the most numbing effect on local government.

The average man hates rates and certain elasses really suffer from them. Take any district you like-and you will find a powerful section of public opinion willing to tolerate the existence of almost any evil, barbarity, scandal, or human suffering for fear of increasing the rates. In an Essex village at the present moment 950 inhabitants are asking for

* The main authority for the facts and figures given in this chapter is Mr. Sidney WebB's Grants in Aid, 1911.

$\dagger$ Grants in Aid, by SinNey WebB. 
a water supply, which is resisted by a few farmers (mostly tenants of absentec landlords) because it would put a little less than a farthing on the rates. $\Lambda$ district within 23 miles of London is without an isolation hospital. A case of diphtheria which oceurred last year in a cottage spread to every member of the family, and there being but one bedroon and a landing, the village nurse could not come. The milk and bread were left on the doorstep in all weathers and whichever of the inmates was least ill took them in. In the result the whole family was hors de combat for months and other eases recurred in the same village. Another distriet within 30 miles of London is also without an isolation lospital. There were one or two eases of scarlet fever in the summer a year or two ago. The schools were closed; the richer residents fled the village with their children and left their houses unoceupied; the holiday tenant of the vicarage threw up his let and the vicar could not get his holiday; the village shopman lost hundreds of pounds in loss of custon. And all because the local authority is afraid of the rates. Shortsighted local economies result in widespread national extravagance. It is in the interests of all to make it worth the ratepayer's while to adopt a more far-secing policy. How ean this be done?

In the first place it must be realised that the taxation of site values and uncarned inerement eannot appreciahly affect rural land as such. Again, any transfer of taxes, such as the inhabited house duty, from the national to the local exchequer is unsound. It would be unfair in its effect as between distriet and district, it would do nothing to stimulate economy, and, like anything else that artificially reduces rates, it would be in effect a bounty to the landlords in respect of all land that pays rent.

The only possible way of keeping the rates low and at the sume time increasing the efficieney of local government is to extend and systematise the subventions that are paid annually from the national to the local exchequer. A national minimum standard of achievement should be set up in every department of local government, the grant in aid in each case being made conditional on the attainment of results coming up to that standard. 
For the last 80 years there has been a gradual increase in the amount of the grants in aid. Mr. Sidney Wcbb has estimated them as follows: In 1830 , under $£ 100,000 ; 1840$, under $£ 500,000$; 1850, about $£ 750,000$; 1860, over

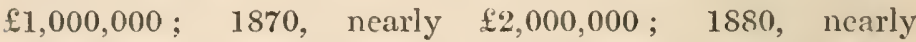
$£ 5,000,000$; 1890 , nearly $£ 12,000,000$; 1900 , nearly $£ 16,000,000$; 1911-12, about $£ 30,000,000$ (or 18 per cent. of the national revenue).*

These grants amount to a reduetion of the rates on the average by 2 s. 4 d. in the pound.

The proportion of the expenses of the various departments of local government borne by the national and local exchequers was as follows in $1908-9 \dagger:-$

\begin{tabular}{|c|c|c|}
\hline Services. & $\begin{array}{l}\text { From, National } \\
\text { Sources. }\end{array}$ & Local Sources. \\
\hline $\begin{array}{lccccc}\text { Police } & \ldots & \ldots & \ldots & \ldots & \ldots \\
\text { Education } & \ldots & \ldots & \ldots & \ldots & \ldots \\
\text { Poor Relief (including } & \text { Pauper } & \text { Lunatics) }\end{array}$ & $\begin{array}{c}\text { Per cent. } \\
40 \\
56 \\
17\end{array}$ & $\begin{array}{c}\text { Per cent. } \\
60 \\
44 \\
83\end{array}$ \\
\hline
\end{tabular}

But these figures represent the total result only; the granls do not really operate in this cut-and-dried fashion.

The rates in the pound paid for the relief of the poor, for instance, are in some Unions over 12 times greater than in

* See Appendix $\mathbf{M}$.

$\dagger$ See Memorandum by County Councils' Association to Departmental Committee on Local Taxation, Cd. 6303, If. On January 6th, 1913, the President of the Local Government Board, in reply to a question in the House of Commons, gave the following table, showing the amount of expenditure on the five services named, which in England and Wales fell on rates and Exchequer grants respectively in the year ending March, 1911 :

\begin{tabular}{lll|r|r} 
Services. & & Rates. & \multicolumn{1}{c|}{$\begin{array}{c}\text { Frchequer } \\
\text { rirants }\end{array}$} \\
\hline
\end{tabular}


others.* Yet it by no means liappens that the national exehequer contributes in similar proportions. 'l'he anıount of relief is haphazard and chatic. 'The grant in aid of the Poor Law expenditure in the Fylde. Union is equivalent to less than $1 \mathrm{~d}$. rate; in the Caxton and Arrington Union it is equivalent to a rate of nearly $1 \mathrm{~s}$. $6 \mathrm{~d}$.

'The Union of Longtown is relieved of over 58 per cent. of its expenditure, but King's Lynn Union of 13 per eent. only. So with edueation. In Durham each scholar costs $56 \mathrm{~s}$. 10 d. a year, of which the locality pays 30 per cent. In Middlesex the cost is 72s. 2d., of which the locality pays 53 per cent. In some of the poorest places the locality has to pay 60 per cent. of the cost of educating its children.

The grants then should be systematised and made conditional. They should be paid for each of the great local services, for education and for the children, for sanitation and the care of the siek, for the poliee, and for roads. When the national standard is not attained the grant would be not fortheoming, the locality would be penalised, and rates would go up. When it is, the locality would receive its grant and the rates would go down. And if larger grants still were given for the attainment of a still higher standard the really progressive communities would have the lowest rates of all. Lunacy, like crime, should be made a national charge. Vagrancy and unemployment should also be taken over entirely by the central government. All old persons and persóns permanently disabled at whatever age should receive State pensions, as some do at present. The existing Poor liate would be thus obviated and national burdens be borne as such by the national exchequer.

The adoption of this poliey would remove the obstacle that blocks the way of progress in every rural district. It would relieve industry and popularise reform. After a course of years it would be followed by a still further relief, both of local and national taxation, as a result. of the increased prosperity and health of the nation at large and the gradual elimination of all the waste and wreckage which at present clogs the whecls of national progress.

* Report of the Royal Commission on Local Taxation. Cd. 638. 1S96. Page 74. 


\section{CHAPTER XIV.}

SUMMARY OF RECOMMENDATIONS.

1. Minimum wage of 23s. for agricultural labourers. A fifty-hour week and one half-holiday a week. Sunday work to be distributed as far as possible.

2. Tenant farmers to have the option of bringing contracts with their landlords to an end within 6 months of the enforeement of the Minimum Wage Aet.

3. A State survey of cottage accommodation. Local authority to be given two years to make up defieieney, failing which no grants in aid from Exchequer for any purpose.

4. Loans to loeal authorities for cottage building to be at lowest rate of interest, coupled with a State grant in aid of cottage building equivalent to the siriking fund, and half defieieney on annual rent account provided such defieiency is properly ineurred.

5. Land Commissioners to be appointed.

6. Powers to Land Commissioners and to loeal authority to acquire land compulsorily at valuation whenever wanted for any purpose, or whenever insuffieiently developed, or in anticipation of future uses.

7. An irredecmable mortgage on land in lieu of part of Death Dutics.

8. Compensation to ontgoing tenant of small holdings not to he eharged to small holder whęn of no value to him. Sinking fund likewise.

9. Experimental farms to be formed by local authority in small-holdings areas.

10. Free farm schools in agrieultural districts.

11. 'Travelling agrieultural instructors.

12. More money and executive powers to be given to 1)evelopment Commission.

13. Nationalisation of railways.

14. State motor service.

15. Afforestation.

16. Grants in aid of local services to be systematised and made conditional on a national minimum standard of efriciency.

17. Abolition of the Poor Rate. 


\section{APIENDIX A.}

CENSUS OF PRODUC'TION, 1907.

HiNal Report. (CD. 6320.) 1912.

Introduction, p. 1: "The Census of Production Act, 1906, required that a census of production should be taken in the year 1908 , in respect of the calendar year 1907. Power was given to the Board of Trade to vary this period in eases where it was found inconvenient to furnish the required particulars in respect of the calendar year 1907 ; and, accordingly, persons required to make Returns were informed that, if the financial year of their establishment was not the calendar year, they might furnish particulars for a period of twelve montlis, ending with any date not earlier than June 30 th, 1907, or later than June 30 th, 1908 . It is believed that, taken as a whole, the Returns substantially represent the productive activity of the United Kingdom during the calendar year 1907."

The Census of Production Oflice Returns did not cover Agrieulture, but by speeial arrangement a voluntary census of agriculture was taken covering the twelve months ended June 4th, 1908, in the case of Great Britain, and the calendar year 1908 in the case of Ireland. Many classes-e.g., persons working on their own account (unless oceupiers of workshops)-were not ineluded.

Pp. 18-19: "The following table summarises the principal particulars returned to the Census of Produetion Ollice regarding the output of the three divisions of the United Kingdom, respeeting which the Census of Production Act requires that separate statisties shall be published :

England and Wales

Gross Output or Selling Value of Work done.

\begin{tabular}{|c|c|c|c|c|c|c|c|c|}
\hline England & nd & & $\cdots$ & & 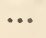 & & & $1,490,749,000$ \\
\hline Scotland & $\ldots$ & $\cdots$ & $\cdots$ & $\cdots$ & ... & $\cdots$ & $\cdots$ & $207,840,000$ \\
\hline Ireland & ... & $\cdots$ & $\cdots$ & $\cdots$ & $\cdots$ & $\cdots$ & $\cdots$ & $66,7 \tau 7,000$ \\
\hline
\end{tabular}

United Kingdom ...

$\cdots \quad \cdots \quad \cdots \quad \cdots$

Gross Output, Selling Value or Value of Work done. $\&$

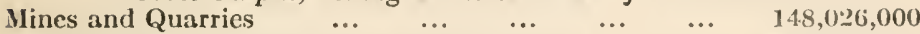

Iron and Steel, Engineering and Shiphuiluing 'Trade's $\quad: 375,196,000$

Metal Trades, other than Iron and Steel ... ...

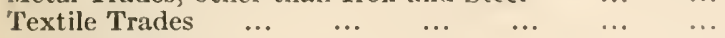

$93,465,000$

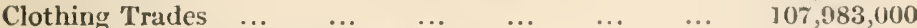

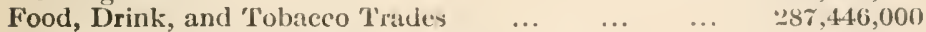

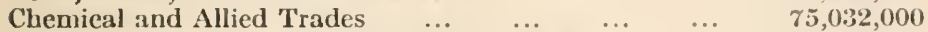

Paper, Printing, Stationery and Allied 'l'valex... ... $61,908,000$

Leather, Canvas and India-rubber 'Trades $\quad \ldots \quad \ldots \quad \ldots \quad 34,928,000$

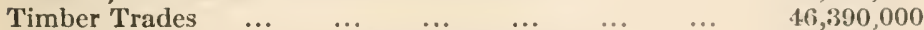

Clay, Stone, Building, and Contracting Trades $\quad \ldots \quad 116,692,000$

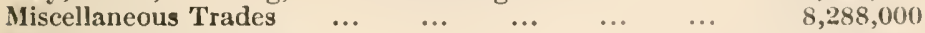

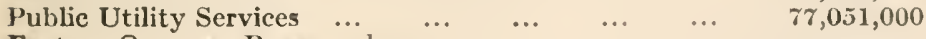

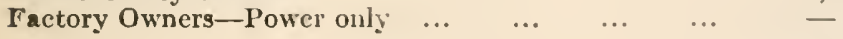

Total $\quad \ldots \quad \ldots \quad \ldots £ 1,765,366,000$ 
" The aggregate of the values returned for the gross output of the various trades is $£ 1,765,366,000$, which does not include the output of agriculture and fishery. This aggregate . . . involves a large amount of duplication."

P. 24: "Bringing together the totals already obtained, and adjusting for the transfer of butter and cheese from the industrial total to the agricultural, we have, for the value of the output:

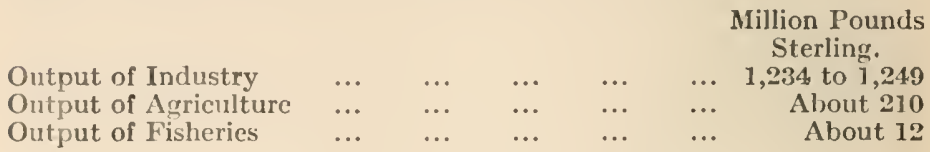

Or a total of $£ 1,456,000,000$ to $£ 1,471,000,000$.

P. 25: "In the following table there are presented figures comparing the value of the output of the United Kingdom (using lower figures of preeeding estimates) with that of exports and of net imports-i.e., imports less re-exports. The figures are arranged in groups, within which the effects of duplieation have been eliminated, so far as each group by itself is concerned. Thus, in "Agriculture," the value of crops used for stock-food and of grain used for seed has been deducted, and in " mines and quarries" the value of coal used in the operation of the mines and quarries has also been deducted.

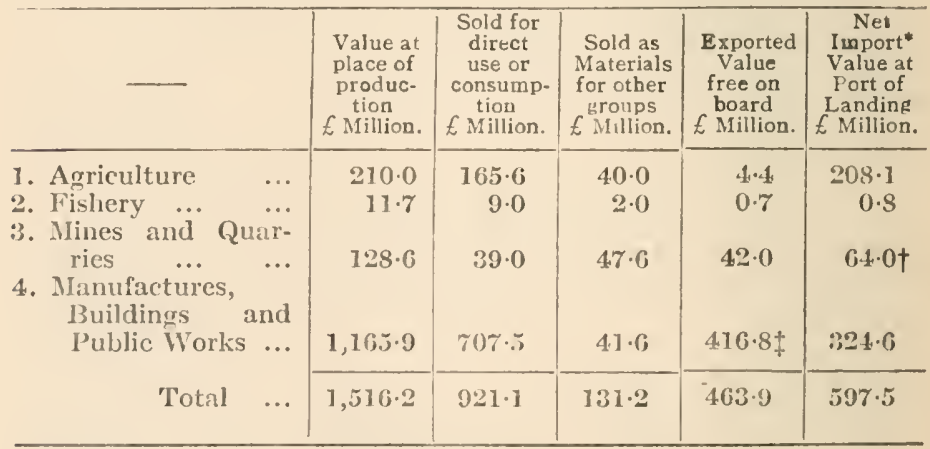

* i.c., imports, less re-exports.

† Ineluding net imports of unrefined gold bullion and of silver bullion for use in industry.

* Including cxport of gold and silver bullion refined in the United Kingdom, and exports (on balance) of British gold and silver coin, less the net imports of foreign and colonial silver eoin (valued as bullion). 


\section{APPENDIX B.}

\section{REPORT OF AN INQUIRY BY THE BOARD OF TRADE INTO THE E.ARNINGS AND IIOURS OF LABOUR OF WORKPEOPLE IN THE UNITED KINGDOM. V.- AGRICULTURE IN 1907. (Cd. 5460.) 1910.}

\section{ENGLAND.}

P. xvi. : "Including the estimated value of food or board and lodging, when provided, and of all other allowanees in kind, the average weekly earnings in 1907 of the four classes of workpeople are given for each district in the table below. The value of cottage has been taken as $\$ 1$ per annum, and board and lodging has been computed at $£ 2016 \mathrm{~s}$. per annum (8s. per week). The average stated represents not the earnings during a given week. but an average of the weekly earnings during the whole year, and takes into consideration the effect of any extra earnings at the busy seasons, and of any reductions during the winter period, or when work was stopped hy bad weather or other causes.

\begin{tabular}{|c|c|c|c|c|c|}
\hline \multirow{2}{*}{ District. } & \multicolumn{5}{|c|}{ Average Weekly Earnings in 1907 of } \\
\hline & $\begin{array}{l}\text { Ordinary } \\
\text { Labo'rers }\end{array}$ & $\begin{array}{l}\text { Horse- } \\
\text { men. }\end{array}$ & $\begin{array}{l}\text { Cattle- } \\
\text { men. }\end{array}$ & $\begin{array}{l}\text { Shep- } \\
\text { herds. }\end{array}$ & $\begin{array}{l}\text { All } \\
\text { classes. }\end{array}$ \\
\hline Northern Counties... & $\begin{array}{rr}\text { s. d. } \\
19 & 2\end{array}$ & $\begin{array}{l}\text { s. d. } \\
21 \\
3\end{array}$ & $\begin{array}{l}\text { s. d. } \\
2111\end{array}$ & s. d. & $\begin{array}{l}\text { s. d. } \\
2010\end{array}$ \\
\hline Yorkshire, Lancashire and & & & & & \\
\hline Cheshire ... $\quad \ldots \quad \ldots$ & 196 & 195 & 203 & 206 & 198 \\
\hline North and West Midland & & & & & \\
\hline $\begin{array}{l}\text { Counties ... } \\
\text { South Midland and Eastem }\end{array}$ & 183 & 186 & 190 & 199 & is 7 \\
\hline $\begin{array}{lll}\text { Counties ... } & \ldots & \ldots\end{array}$ & 16 & 181 & 184 & 189 & 173 \\
\hline South-Fastern Counties ... & 18 & 1811 & 198 & 190 & 189 \\
\hline South-Western Counties ... & 1610 & 174 & 180 & 183 & 174 \\
\hline Total-England & 176 & 189 & 191 & 197 & 184 \\
\hline
\end{tabular}

"It will be observed that in all four occupatious earnings in the Northern Counties, Yorkshire, Laneashire, and Cheshire, and the South-Fastern Counties were above the general averages for England, whilst in the South Midland and Eastern Counties and the South-Western Counties they were below those averages."

\section{Ordinary Labourers.}

P. xvii.: "The following table gives for each county and district, except Northumberland and Durham, the average weekly earnings in 1907 of ordinary agrieultural labourers, and shows how 
much is represented by cash rates of pay, and how much by extra earnings, whether paid in cash or in kind.

\begin{tabular}{|c|c|c|c|c|c|c|}
\hline \multicolumn{3}{|l|}{ County. } & $\begin{array}{c}\text { Average } \\
\text { Rates of } \\
\text { Cash Wages } \\
\text { per week. }\end{array}$ & $\begin{array}{l}\text { Extra } \\
\text { Earnings and } \\
\text { Estimated } \\
\text { Value of } \\
\text { Allowances } \\
\text { in Kind per } \\
\text { week. }\end{array}$ & \multicolumn{2}{|c|}{$\begin{array}{l}\text { Average } \\
\text { Earnings } \\
\text { per week }\end{array}$} \\
\hline \multicolumn{3}{|l|}{ Northern Counties : } & s. d. & s. d. & s. d & \\
\hline Northumberland & $\ldots$ & $\ldots$ & - & - & 一 & \\
\hline Durham $\quad \ldots$ & $\ldots$ & $\ldots$ & $\cdots$ & - & - & \\
\hline Cumberland $\quad \ldots$ & $\cdots$ & $\ldots$ & $12 \quad 2$ & 71 & 19 & \\
\hline Westmorland ... & $\cdots$ & $\cdots$ & 119 & 74 & 19 & 1 \\
\hline Total ... & $\cdots$ & $\ldots$ & 120 & $7 \quad 2$ & 19 & 2 \\
\hline \multicolumn{7}{|c|}{$\begin{array}{l}\text { Yorkshire, Lancashire, and } \\
\text { Cheshire : }\end{array}$} \\
\hline \multirow{3}{*}{\multicolumn{2}{|c|}{$\begin{array}{cl}\text { Yorkshire, } & \text { East Riding } \\
\text {," } & \text { North Riding } \\
, & \text { West Riding }\end{array}$}} & $\ldots$ & $16: 5$ & 210 & 19 & 3 \\
\hline & & $\ldots$ & 160 & 210 & 19 & 7 \\
\hline & & $\ldots$ & 176 & & 20 & 0 \\
\hline \multicolumn{2}{|c|}{, Whole County } & $\ldots$ & 1611 & & 19 & $\tau$ \\
\hline Ianeashire $\quad \ldots$ & $\ldots$ & $\ldots$ & 162 & 38 & 191 & 10 \\
\hline Cheshire $\quad \ldots$ & $\cdots$ & $\cdots$ & 167 & 25 & 19 & 0 \\
\hline Total ... & $\cdots$ & $\cdots$ & 167 & 211 & 19 & 6 \\
\hline \multicolumn{7}{|c|}{$\begin{array}{l}\text { North and West Midland } \\
\text { Counties: }\end{array}$} \\
\hline Leicestershire ... & ... & $\ldots$ & $16 \pi$ & $\ddot{2} 2$ & 18 & 9 \\
\hline Rutland $\quad \ldots$ & ... & $\ldots$ & 14. 10 & & 17 & 0 \\
\hline Lincolnshire $\quad .$. & $\ldots$ & $\ldots$ & 153 & & 19 & 5 \\
\hline Nottinghamshire & $\ldots$ & $\ldots$ & 172 & 23 & 19 & .5 \\
\hline Derbyshire $\quad .$. & ... & $\ldots$ & 175 & & 20 & 5 \\
\hline Gloucestershire & $\ldots$ & $\ldots$ & 1311 & & 16 & 3 \\
\hline Herefordshire ... & ... & $\ldots$ & 1311 & & 17 & 1 \\
\hline Shropshire $\quad \ldots$ & $\ldots$ & $\ldots$ & $14 \%$ & ;; ; & 18 & () \\
\hline Staffordshire ... & $\ldots$ & $\ldots$ & 1510 & $\because 10$ & 18 & 8 \\
\hline Woreestershire... & $\cdots$ & $\ldots$ & 146 & & 16 & 3 \\
\hline Warwickshire ... & $\cdots$ & $\cdots$ & 154 & 110 & 17 & 2 \\
\hline Tot:it .. & $\cdots$ & $\cdots$ & $1 ;: 3$ & $30^{-}$ & 18 & $\because$ \\
\hline \multicolumn{7}{|c|}{$\begin{array}{c}\text { Soutlı Mislland and liantern } \\
\text { Counties: }\end{array}$} \\
\hline Middlesex & $\ldots$ & $\ldots$ & is $\pi$ & $1 s$ & 211 & 3 \\
\hline IIertfordshire ... & $\ldots$ & $\ldots$ & 148 & $\ddot{2} 2$ & $16 ; 1$ & 10 \\
\hline Buckinghamsluie & ... & $\ldots$ & 14. 10 & 21 & $16 j 1$ & 11 \\
\hline ()xfordshire $\quad .$. & ... & $\ldots$ & 1211 & 2011 & 1.41 & 11 \\
\hline Northamptonshire & ... & $\ldots$ & 1.6 & $2: 3$ & 16 & 9 \\
\hline
\end{tabular}




\begin{tabular}{|c|c|c|c|c|c|}
\hline \multicolumn{3}{|l|}{ County. } & $\begin{array}{c}\text { Average } \\
\text { Rates of } \\
\text { Casb Wages } \\
\text { per week. }\end{array}$ & $\begin{array}{l}\text { Extra } \\
\text { Earning's and } \\
\text { Estimated } \\
\text { Value of } \\
\text { Allowances } \\
\text { in Kind per } \\
\text { week. }\end{array}$ & $\begin{array}{l}\text { Average } \\
\text { Earnings } \\
\text { per week. }\end{array}$ \\
\hline \multicolumn{3}{|c|}{$\begin{array}{l}\text { South Midland and Eastern } \\
\text { Counties-continued. }\end{array}$} & s. d. & s. d. & s. d. \\
\hline Huntingdonshire & $\ldots$ & $\ldots$ & 135 & 29 & 162 \\
\hline Bedfordshire & $\ldots$ & $\ldots$ & 139 & 26 & 163 \\
\hline Cambridgeshire & $\ldots$ & $\ldots$ & 133 & 30 & 163 \\
\hline Essex $\quad \ldots$ & $\ldots$ & $\ldots$ & 137 & 29 & 164 \\
\hline Suffolk ... & $\ldots$ & $\ldots$ & 125 & 34 & 159 \\
\hline Norfolk & $\cdots$ & $\ldots$ & & 29 & 154 \\
\hline Total ... & $\cdots$ & $\ldots$ & 135 & 28 & 161 \\
\hline \multicolumn{3}{|c|}{ South-Eastern Counties : } & & & \\
\hline Surrey ... & $\ldots$ & $\ldots$ & 168 & & 189 \\
\hline Kent $\quad \ldots$ & $\ldots$ & $\ldots$ & 164 & 26 & 1810 \\
\hline Sussex ... & $\ldots$ & $\ldots$ & 151 & 28 & 179 \\
\hline Hampshire & $\ldots$ & $\ldots$ & 140 & 35 & 175 \\
\hline Berkshire & $\ldots$ & $\ldots$ & 139 & 211 & 168 \\
\hline Total ... & $\ldots$ & $\ldots$ & 154 & 29 & 181 \\
\hline \multicolumn{3}{|c|}{ South-IVestern Counties : } & & & \\
\hline Wiltshire & $\ldots$ & $\ldots$ & 130 & & 160 \\
\hline Dorsetshire & $\ldots$ & $\ldots$ & 121 & 40 & $16 \quad 1$ \\
\hline Devonshire & $\ldots$ & $\ldots$ & 146 & 33 & 179 \\
\hline Cornwall & ... & $\ldots$ & 150 & & 177 \\
\hline Sómersetshire ... & $\ldots$ & $\ldots$ & 140 & 33 & 173 \\
\hline Total ... & $\ldots$ & $\ldots$ & 136 & 34 & 1610 \\
\hline Total, Ex & AND & $\ldots$ & 146 & $: ; 0$ & 176 \\
\hline
\end{tabular}




\section{Horskiten.}

P. xviii. : "The following table gives particulars of average eash rates of wages and average weekly earnings of horsemen, corresponding to those given on the previous page for ordinary agricultural labourers :

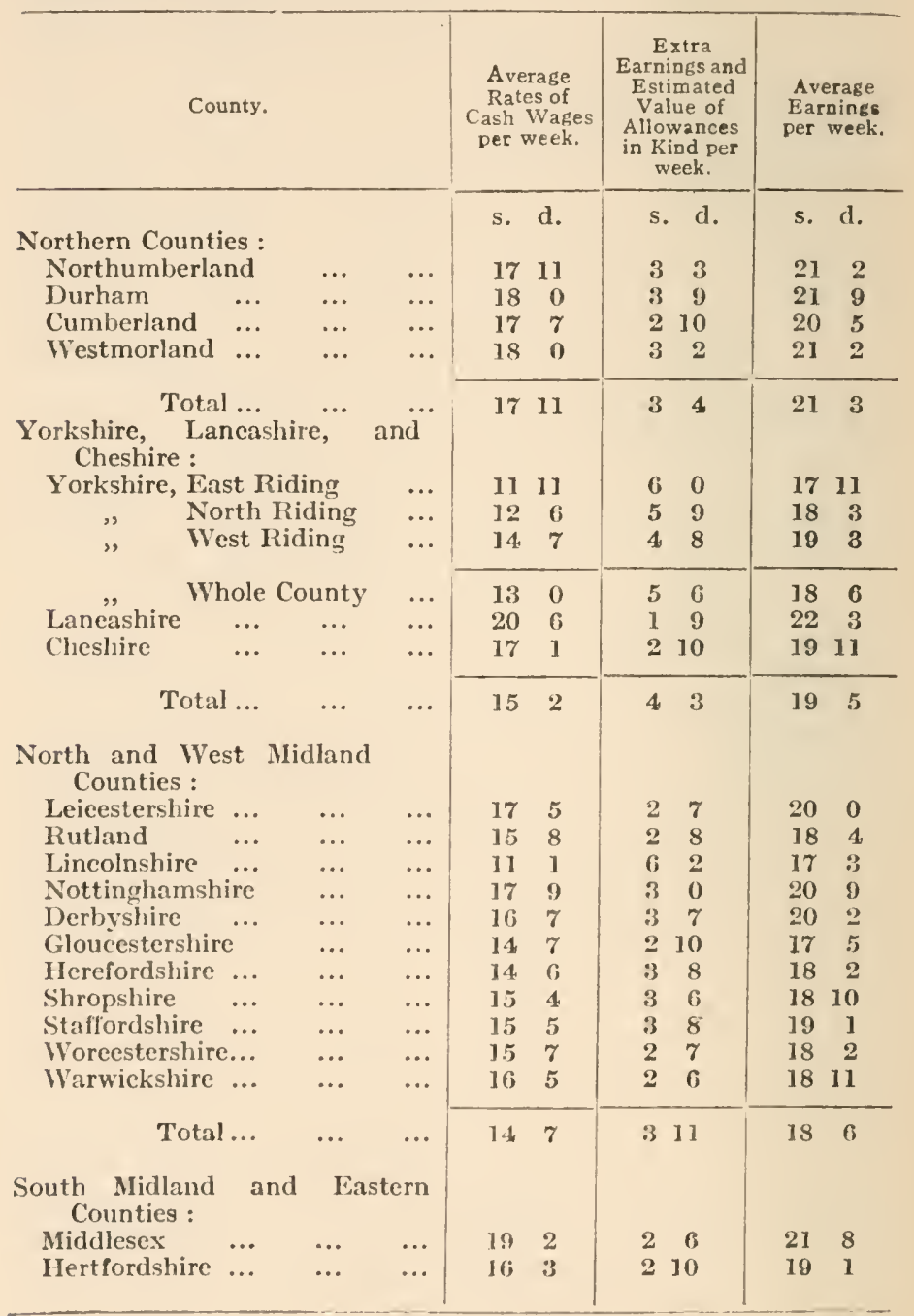




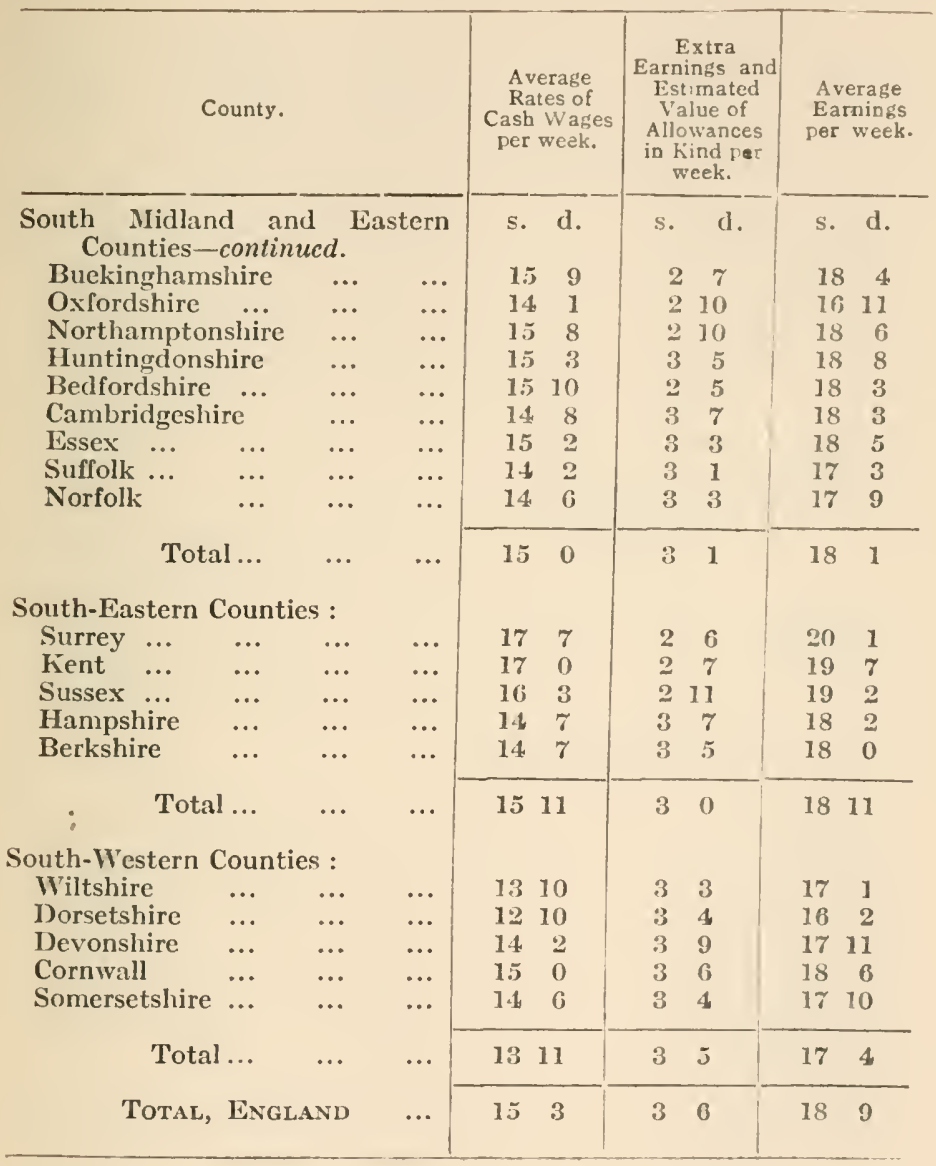




\section{Cattlemen.}

P. xix. : "The average cash rates of pay and the average total earnings per week of cattlemen in 1907 are shown in the table below for each county and district :

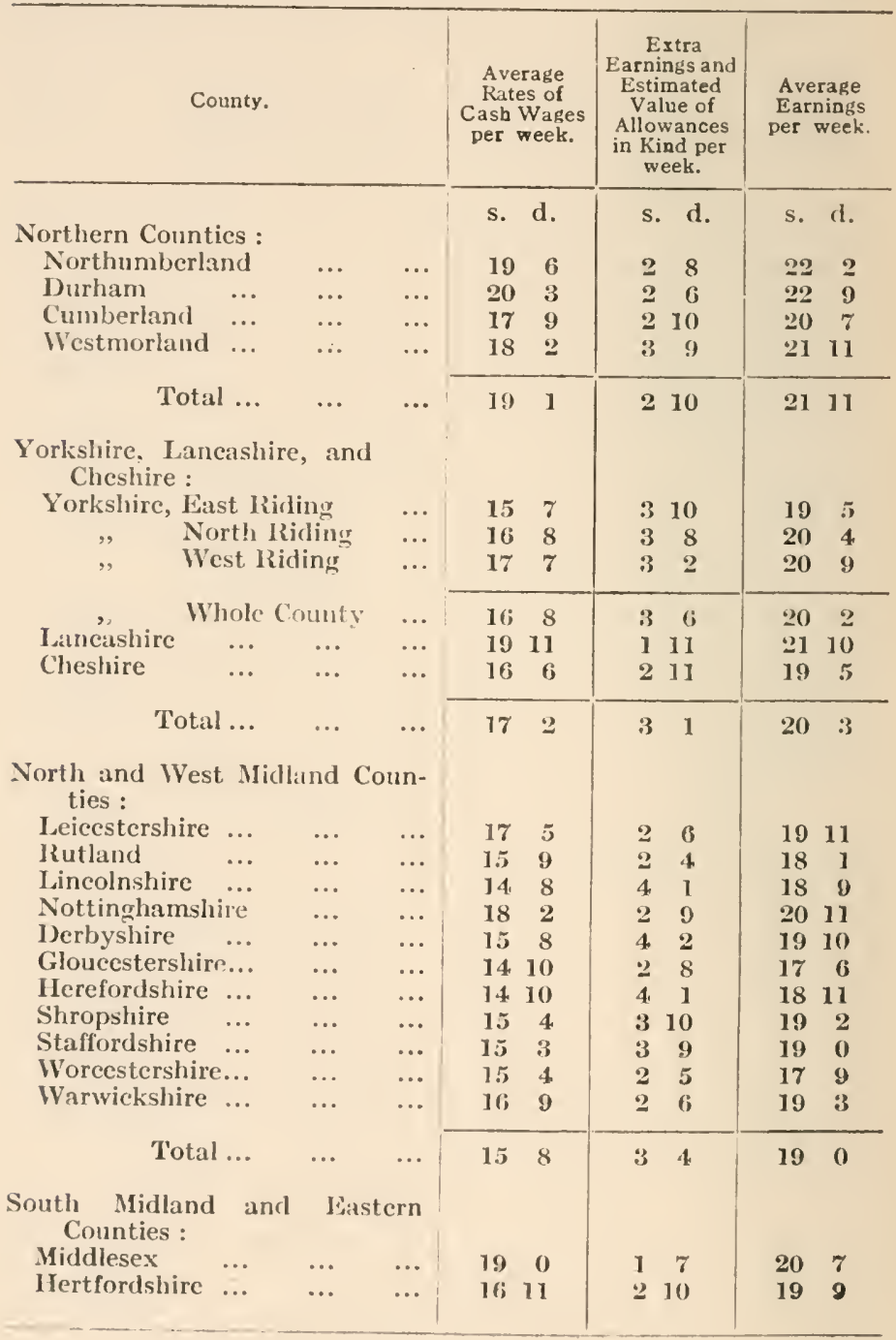




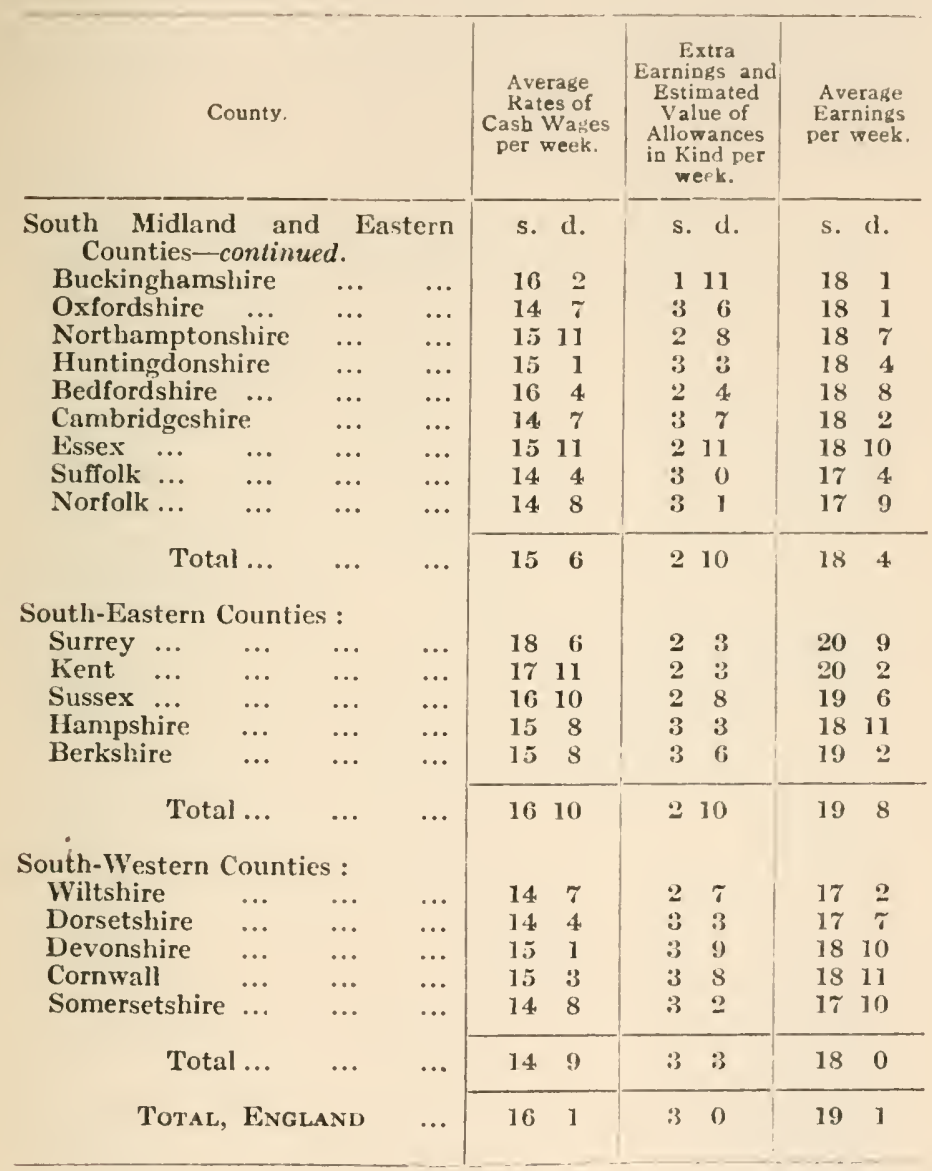




\section{Sirfinerdos.}

P. xx. : "Shepherds, though numerous in some distriets, are a eomparatively small elass of agricultural labourers when England is considered as a whole. Their average earnings, however, of whieh partieulars are given in the table below, were greater than those of any of the other classes of labourers.

\begin{tabular}{|c|c|c|c|c|c|}
\hline \multicolumn{3}{|l|}{ County. } & $\begin{array}{c}\text { Average } \\
\text { Rates of } \\
\text { Cash Wages } \\
\text { per week. }\end{array}$ & $\begin{array}{l}\text { Extra } \\
\text { Earnings and } \\
\text { Estimated } \\
\text { Value of } \\
\text { Allowances } \\
\text { in Kind p.r } \\
\text { week. }\end{array}$ & $\begin{array}{c}\text { Average } \\
\text { Earnings } \\
\text { per week. }\end{array}$ \\
\hline Northern Counties : & & & s. d. & & s. d. \\
\hline Northumberland & $\cdots$ & $\cdots$ & 198 & 310 & 236 \\
\hline Durham , ... & $\ldots$ & $\ldots$ & 210 & 43 & 253 \\
\hline Cumberland ... & $\ldots$ & ... & 173 & 310 & $21 \quad 1$ \\
\hline Westmorland ... & $\cdots$ & $\cdots$ & & 311 & 233 \\
\hline Total ... & $\ldots$ & $\cdots$ & 196 & 311 & 235 \\
\hline \multirow{4}{*}{\multicolumn{2}{|c|}{$\begin{array}{cl}\begin{array}{c}\text { Yorkshire, } \\
\text { Cheshire }\end{array} & \text { Lancashire, } \\
\text { Yorkshire, East Riding } & \text { North Riding } \\
,, & \text { West Riding }\end{array}$}} & and & & & \\
\hline & & $\cdots$ & 168 & & 109 \\
\hline & & $\cdots$ & $\begin{array}{ll}16 & 11 \\
17 & 11\end{array}$ & $\begin{array}{ll}3 & 7 \\
3 & 4\end{array}$ & $\begin{array}{ll}20 & 6 \\
21 & 3\end{array}$ \\
\hline & & $\cdots$ & & & 213 \\
\hline \multicolumn{2}{|c|}{ Whole County } & $\ldots$ & 172 & 33 & 205 \\
\hline Lancashire $\quad \ldots$ & $\ldots$ & ... & 1710 & & 2011 \\
\hline Cheshire & $\ldots$ & $\cdots$ & 1711 & 211 & 2010 \\
\hline Total ... & $\ldots$ & ... & 173 & 33 & 206 \\
\hline $\begin{array}{l}\text { North and West } \\
\text { Counties : }\end{array}$ & \multicolumn{2}{|c|}{ Midland } & & & \\
\hline Leicestershire ... & ... & ... & 178 & & 208 \\
\hline Rutland ... & $\ldots$ & ... & 168 & 36 & 202 \\
\hline Lincolnshire ... & $\ldots$ & $\ldots$ & 153 & 48 & 1911 \\
\hline Nottinghamshire & $\ldots$ & ... & 185 & 33 & 218 \\
\hline Derbyshire ... & $\cdots$ & $\cdots$ & 1610 & 38 & 206 \\
\hline Gloucestershire & $\cdots$ & ... & 148 & 38 & 184 \\
\hline Hercfordshire ... & $\ldots$ & ... & 149 & 50 & 199 \\
\hline Shropshire $\quad \ldots$ & $\ldots$ & $\cdots$ & 156 & 47 & 201 \\
\hline Staffordshire ... & $\ldots$ & ... & 161 & 40 & 201 \\
\hline Woreestershire... & $\cdots$ & $\cdots$ & 1.56 & 25 & 1711 \\
\hline Warwickshire ... & $\cdots$ & $\cdots$ & 165 & 32 & 197 \\
\hline Total ... & $\cdots$ & $\ldots$ & 1510 & 311 & 199 \\
\hline
\end{tabular}




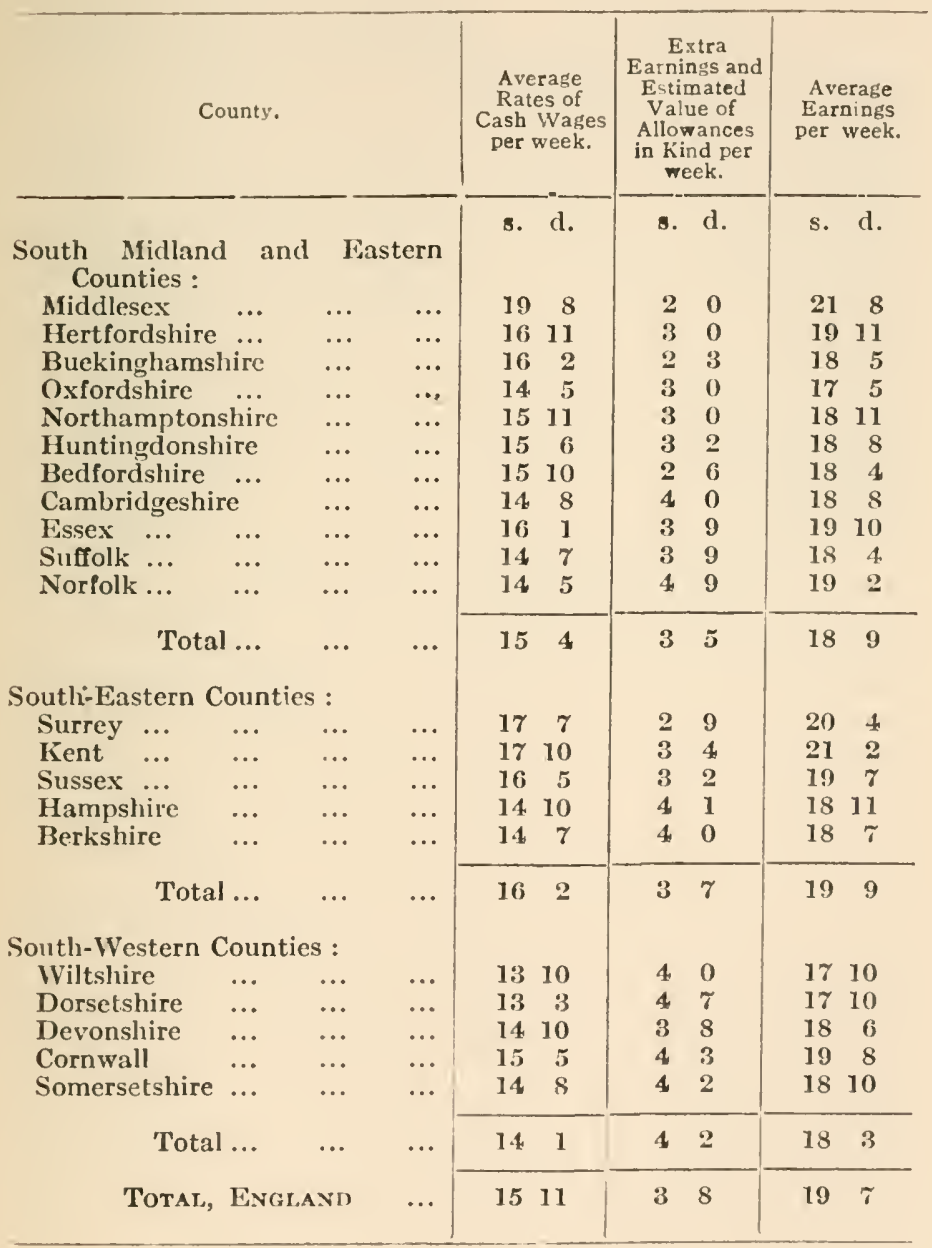


Wales and Monmouthshire.

P. xxi. : "The following table gives the average cash rates of pay and the average total earnings per week, in 1907, in each county of Wales and in Monmouthshire, of all the men included in the returns received:

\begin{tabular}{|c|c|c|c|c|c|c|}
\hline \multicolumn{3}{|c|}{ County. } & & $\begin{array}{c}\text { Average } \\
\text { Rates of } \\
\text { Cash Wages } \\
\text { jer week. }\end{array}$ & $\begin{array}{c}\text { Extra } \\
\text { Earning's and } \\
\text { Estimated } \\
\text { Value of } \\
\text { Allowances } \\
\text { in Kind } \\
\text { per week. }\end{array}$ & $\begin{array}{l}\text { Average } \\
\text { Earnings } \\
\text { per week. }\end{array}$ \\
\hline $\begin{array}{l}\text { Flintshire ... } \\
\text { Denbiglishire } \\
\text { Carnarvonshire } \\
\text { Anglesey ... } \\
\text { Merionethshire } \\
\text { Montgomeryshire } \\
\text { Cardiganshire } \\
\text { Radnorshire }\end{array}$ & $\begin{array}{l}\cdots \\
\cdots \\
\cdots \\
\cdots \\
\cdots \\
\cdots \\
\cdots \\
\cdots\end{array}$ & $\begin{array}{l}\cdots \\
\cdots \\
\cdots \\
\cdots \\
\cdots \\
\cdots \\
\cdots\end{array}$ & $\begin{array}{l}\cdots \\
\cdots \\
\cdots \\
\cdots \\
\cdots \\
\cdots \\
\cdots\end{array}$ & $\begin{array}{lr}\text { s. } & \text { d. } \\
15 & 11 \\
13 & 11 \\
13 & 10 \\
11 & 9 \\
13 & 3 \\
10 & 8 \\
11 & 6 \\
11 & 1\end{array}$ & $\begin{array}{rr}\text { s. } & \text { d. } \\
2 & 11 \\
4 & 2 \\
+ & 9 \\
5 & 9 \\
4 & 11 \\
3 & 11 \\
5 & 0 \\
5 & 7\end{array}$ & $\begin{array}{lc}\text { s. } & \text { l. } \\
18 & 10 \\
18 & 1 \\
18 & 7 \\
17 & 6 \\
18 & 2 \\
16 & 7 \\
16 & 6 \\
16 & 8\end{array}$ \\
\hline $\begin{array}{l}\text { Breeknoekshire } \\
\text { Carmarthenshire } \\
\text { Pembrokeshire } \\
\text { Glamorganshire } \\
\text { Mlommouthshire }\end{array}$ & $\begin{array}{l}\cdots \\
\cdots \\
\cdots \\
\cdots\end{array}$ & $\begin{array}{l}\cdots \\
\cdots \\
\cdots \\
\cdots\end{array}$ & $\begin{array}{l}\cdots \\
\cdots \\
\cdots \\
\cdots \\
\cdots\end{array}$ & $\begin{array}{ll}14 & 7 \\
13 & 9 \\
12 & 9 \\
15 & 8 \\
14 & 9\end{array}$ & $\begin{array}{ll}4 & 2 \\
4 & 4 \\
4 & 6 \\
: 3 & 7 \\
3 & 4\end{array}$ & $\begin{array}{ll}18 & 9 \\
18 & 1 \\
17 & 3 \\
19 & 3 \\
18 & 1\end{array}$ \\
\hline $\begin{array}{l}\text { Total, } \\
\text { MoN }\end{array}$ & $\begin{array}{r}\text { WV } \\
\text { HOUT }\end{array}$ & $\begin{array}{l}\text { HSS } \\
\text { HIRE }\end{array}$ & $\begin{array}{c}A \times D \\
\ldots\end{array}$ & $1: 9$ & $4: 3$ & 18 \\
\hline
\end{tabular}




\section{APPENDIX C.}

THE FOLLOWING IS A TYPICAL REPORT FROM AN INVESTIGATOR ON THF WAGLS OF AGIRICULTURAI. LABOUREIRS IN TIUE MID-DIVISION OF OXFORDSHIRE.

'The ordinary agricultural labourer works from 7 to 5 , less $1 \frac{1}{3}$ hours for meals, 6 days a week $=51$ hours.

The usual rate of wages is $12 \mathrm{~s}$. per week, or under $3 \mathrm{~d}$. an hour : but in some districts a fair proportion of the labourers get 13s., and a few $14 \mathrm{~s}$. per week. I know of three farmers who employ no man at less than $15 \mathrm{~s}$. per week, but it is alleged by other farmers that the men work longer hours, and probably this is true.

When the wages are over 12s. per week, it appears to be due to the employer being more generous than his fellows, or to the individual labourer being an exceptionally good workman. In some few instances the higher rate has been due to the inability of the employer to get men to work for $12 \mathrm{~s}$., but I am inelined to think that sueh eases are very rare.

Here and there one hears of men working for $11 \mathrm{~s}$. per week. but I have come to the conelusion that in such eases the men have some mental or physical deficiency which prevents them doing a fair day's work. (Low wages doubtless the cause of this as well as the effect.)

'The wages mentioned are for " day-work," and some employers send their men home on wet days, and the men earn nothing. It is this "losing wet time" that accounts for the perfectly aceurate statement of Mr. George Edwards that he heard of agricultural labourers in this county who only earned $10 \mathrm{~s}$. or $11 \mathrm{~s}$. per week, but the employers of such men would strenuously deny that they paid any man less than $12 \mathrm{~s}$. per week. 'This system of stopping the men on wet days appears to be a practiee of individual enployers rather than a general eustom.

It is seldom that this class of labourer gets a cottage rent free. Usually he pays from 1s. 6d. to 2s. 6d. per week.

Allowances of milk, fuel, ete., are exceptional, and it is only a small minority who get an allotment rent free.

It appears to be impossible to obtain an average of the "extra earnings " of these labourers, as custom varies widely in different parishes. In some parishes all the men get extra in hay and coln harvests is two or three pints of beer, or 4d. per day as its equivalent, although they work three or four hours longer every day. In other villages they get $15 \mathrm{~s}$. per week and 6d. per day "beer-money," or its equivalent in beer. for about ten weeks instead of their ordinary week's wage of 12s. In others they get $3 \mathrm{~d}$. per hour overtime plus $6 \mathrm{~d}$. per day " beer-money." In others a lump sum is paid at the end of the lay harvest, and a further 
sum at the end of the corn harvest. When this is done the aggregate for both harvests varies from 25s. to $\mathfrak{\&} 4$.

It is still more difficult to ascertain what extra is earned by piece-work being substituted for day-work at certain seasons of the year. The men say that if more is earned it is only by working longer hours, and in the main I think this is true. Of course, they get nothing if the weather is such that they are unable to work.

After collecting all the information I could-from the farmers as well as from the labourers-I think that the "extra earnings" of the ordinary labourer from all sourees-hay and corn harvest, piece-work, overtime, etc.-seldom exceed $£ 5$ per annum.

Carters, stoekmen and shepherds are better paid but have some Sunday work, and their usual hours of labour are longer than those of the ordinary farm labourers. Their wages vary fron 13s. to $17 \mathrm{~s}$. per week, and in most cases a cottage is found for them rent free.

Shepherds are usually allowed extra pay, and sometimes fuel during the lambing and shearing seasons.

Cowmen are allowed milk all the year round.

Carters earn extra money at harvest time, the amount being very much the same as that paid to the ordinary labourers on the same farm.

It is safe to say that the average carnings of a carter, shepherd or stoekman of average ability are not less than $14 \mathrm{~s}$. per week with a cottage, or $16 \mathrm{~s}$. per week without one.

General Remarks.-While making this inquiry, I found myself continually wondering whether and to what extent the drift of the best workers to the towns or abroad, coupled with the low standard of living in the villages, has lessened the efficiency of the farm labourers in Oxfordshire. Two Conservative farmers have told me that Oxfordshire labourers at 12s. per week are more expensive than the labourers they lad paid $15 \mathrm{~s}$. per week elsewhere, and although neither of them took kindly to my suggestion that they should try the experiment of paying $15 \mathrm{~s}$. per week in Oxfordshire, it is probable that there is an element of truth in their statement. 


\title{
APPENDIX D.
}

ALLO'TMENTS.

\author{
By E. R. Pease.
}

The history of allotments goes back, in principle, to the Elizabethan period, when laws were enacted that every cottage built must have an acre of garden. In the Inclosure Acts of the eighteenth century, land was frequently allocated for allotments, and this was also provided for in the Gencral Inclosure Act, 1845. The Poor Law Relief Act, 1819, and two Acts of 1831, empowered churchwardens and overseers to hire, purchase, or enclose land up to 50 acres for allotments. An Act of 1882 further requires any land held in trust for charities to be let for allotments.

The principal Acts are the Allotments Act of 1887 , which was administered till 1907 by District Councils, and the Local Government Act of 189 1, which empowered Parish Councils to acquire land for allotments. By the Act of 1907 (now 1908) district allotments and all powers in connection with allotments were transferred to Parish Councils, and the Act of 1908 embodied and repealed the Act of 1887. County Councils have default powers, and Urban Authorities can and do exercise the allotment powers of Parish Councils. Indeed, whilst small holdings are virtually a purely rural institution, allotments are of high importance for town workmen, and quite a large area is administered by Town and Urban District Councils for the benefit of more people than are concerned with state-provided rural allotments.

An allotment is a small piece of land let as a garden apart from a cottage. Everywhere considerable areas are so let by private owners, and indeed the Act does not allow a Local Authority to exercise its powers unless it is satisfied that land will not be provided by private owners. There is no record of the area of land let as allotments by the owners direct.

It used to be said that an allotment was a garden for a person who made his living otherwise; a small holding was a piece of land off which a man made his living. That is still, on the average, true, though not by any means invariably so. Some allotment holders earn their livings thercof, and many small holders use a holding as a subsirliary source of income. But by law a small holding is land provided by a County Council (or under the Small Folding Sections of the Act), and an allotment is land provided by a Parish Council, or under the Allotment Sections.

The Board of Agriculturc Report on Allotments for 1912 (Cd. 6832) shorvs that $\tau, 1.43$ acres of allotments were ownerl, and 23,9.46 acres lcascd, by Local Authorities in England and Wales, 
and the occupiers numbered 117,562 individuals and 21 associations. Of the total, 21,498 acres, 49,545 individuals, and 2 associations were rural; 9,591 acres, 68,017 individuals, and 19 associations were urban. The acreagc acquired during 1912 was 1,259 , providing for 8,532 applicants. The unsatisfied demand is by 11,789 individuals and 4 associations for 4,522 acres.

In five years-1907-12-4 compulsory purchase orders have been sanctioned and 29 compulsory hiring orders, and in the same five years loans for allotments amounting to $\$ 148,683$ have been approved.

The Act of 1907 allowed Allotment Authorities to build cottages on allotments of not less than 1 acre. In early years a large number of cottages were applied for, but to this day not a single one has been erected. In 1912 Urban Authorities had applications for 29 cottages and rural for 27 , but not one of these has been built, and the report does not disclose whether the veto comes from the Local Government Board or from the Board of Agriculture, or from the authorities themselves. The Board of Agrieulture takes pride in seeking to ascertain if an applicant for a cottage on an allotment wants the cottage more than he wants the land. If it is satisfied that this is the ease, it objects to the project on the plea that it is not a Housing Authority.

Reforms required in existing law are of small importance. The financial provisions occasionally cause hardships, and the faet that only the labouring population are entitled to claim the assistance of the law is a grievance for citizens who do not come within the legal definition of that singular phrase. 


\section{APPENDIX E. \\ CONFIDENTIAL REPORT BY AN INVESTIGATOR ON $A$ SOUTH OF ENGLAND VILLAGE.}

A desolate deserted village; erazy houses, ill-kept, rarely repaired, with gaps in the streets where houses have fallen down. Each year some houses have been condemned. No houses built in the last 60 years. The houses stand as they fall into ruin, the heaps of stone, roofing, and timbers lying there. Grass is growing in the streets. The whole village and surroundings owned by _- typical of the worst form of landlord; he will not sell or lease land for small holdings, nor repair his houses, or do anything whatever to improve condition of the village. IVages on farms, 11s. to 14.s. a week, more often 11s.; farmer charges 2s. $6 \mathrm{~d}$. for eottage and 1s. in some eases a lug for allotment land ( 8 an aere), paying 10s. on big farms themselves. Farms very large, very little labour employed, very poor cultivation. Every natural advantage for prosperity, exeept being 8 miles from train (the ancestor of present landlord refused land for Great Western Railway to go through); lies on main London Road to _- ; good soil, well watered in low lands; eommon lands on high downs still open ; considerable number of men eager for land.

Sample cases of overerowding.

Houses almost falling down; bedrooms and windows very small.

W. V., - - Street ; 3 bedrooms (originally 2 , one partitioned off more like a eupboard). Father, mother, mother-in-law, sister-in-law, 3 grown-ıp sons, and 1 grown-up daughter.

L. - Street ; 3 bedrooms (one a partition as above). Father, mother, 3 lodgers (labourers), son 21, daughter 15, son 6 ; grownup daughter oceasionally at home.

IV., 1 Street; 2 small bedrooms. Father, mother, 3 sons, 1 grown-lip daughter.

B., - - Street ; 2 tiny bedrooms. Father, mother, 7 growing boys and girls at school, 1 baby.

E., _ Main Road; 2 bedrooms (one leading through the other). Father, mother, 3 grown-up sons, 3 cliildren at school, 1 little one.

I saw Medical Officer of Health Was told I should find him entirely in support of landlord, being dependent upon him, and living in one of his houses, as all in the village do.

Medical Officer of Health assured me that " _ — was no worse than other villages, perhaps not so bad." Pressed him for a worse. He would not say. He considered health very good, overerowding the natural habit of the people, same in all villages. They did not want houses because no employment, and people 
always going left houses vacant. I asked if any decent labourer's cottage was to be had. He thought not; none was wanted. Had any house ever been built? Not in the 20 years he had been there. Did he consider houses sanitary and properly repaired? He should say no worse than other villages; come to that, all old houses were insanitary; some repairs had been done of late.

Saw Clerk of Union Offices, who wished his name not to appear. Considered houses disgraceful ; poverty and unemployment bad ; people tied so much by dependence on landlord, ventured to ask for notling. Land impossible to get ; farms so large, small holdings could easily be divided off. Considered if we secured inspection many houses would be condemned, but none would be built ; eause more hardship to people. Till land is opened, not much use for houses. Village undoubtedly dying out; tanning and other trades have left it. Sympathetic to our efforts, but pessimistic under present Aets. Impossible to ask signatures in village, where all dread eviction and dependent on one landlord, but could get same, if advisable, in neighbouring parishes in same distriet. 


\section{APPENDIX F. \\ STATE ACTION IN FIXING WVAGES.}

By W. Stepien Sanders.

Apart from the insertion of fair wages clauses in Government and Municipal eontracts and the fixing of minimum rates for public servants and employees by central and loeal authorities, various methods have been adopted, especially in Australasia, to establish legal minima of wages for all workers. The following are the methods which have been adopted in that part of the world :

I. Ratification of I'oluntary Agreements. - Under the labour laws of New Zealand and Australia, voluntary agrecments arranged between the organised workers and organised employers may be ratified by the State. The effect of such ratifieation is to make the agrecment binding on all employers engaged in the industry, whether they were parties to the voluntary agreement or not. It also gives the employees the definite legal right to receive the standard rate. It is to be noted that, under this arrangement, always inplicitly, and sometimes explieitly; the employees are forbidden to strike for more than the standard rate.

II. Arbitration Courts.--Under the New Zealand Arbitration Act, passed in 1894 , all industrial disputes which cannot be otherwise settled are referred to an Arbitration Court. Fither party may refer any matter in dispute to the Court, whereupon the Court has power to give an award which has all the force of law. The Court ean prescribe a minimum wage or a graduated series of standard rates, and ean regulate the hours of work and all other conditious of employment.

Compulsory arbitration under the above-mentioned Act has been in operation in New Zealand for eighteen years, and although there has been considerable friction from time to time, many beneficial results have been achicved, and there does not appear to be sufficient dissatisfaction with the system to lead to any likelihood of its repeal. 'There are, however, many objcctions to compulsory arbitration, and under the conditions which exist in England these objections (especially the inevitable limitation of the right to strike) are likely to prove insuperable.

III. Trade Boards.-The most satisfactory and successful method of raising wages by State action which has yet been discovered is that of "Trade Boards," which were first adopted in Victoria, in 1896. The system was first applied to five trades, including clotling, furniture, shirt-making, and baking, in which the workers were indisputably underpaid. Since then it has spread to trade after trade, and from 1908 there has been a positive rush of trades, employers and workpeople showing almost equal 
anxiety to get their industry brought within the operation of the Act. 'To-day more than nine-tenths of all the faetory workers in Victoria (and a large proportion of the other workers) are employed under conditions as to hours and wages which have been legally determined by a Trade Board.

Any industry may be brought under the Aet by application of the employers or workpeople to the Minister of Labour, who, if he approves, thereupon moves a resolution which must be passed by both Houses of the Legislature. The Minister then constitutes a Board with an equal number of representatives of employers and workpeople.

The Board has power not only to fix a minimum wage, but to deal with all the conditions of the contract between the employer and workpeople, wages, hours, overtime, holidays, proportion of apprentices or improvers, definition of different elasses of employers within the same trade, etc, etc.

In every instance Trade Boards have brought about inerease of wages, generally very substantial inereases, and at the same time they have secured an almost universal eight-hours day for factory workers, besides preventing the exploitation of boy and girl labour. Yet there is not the least evidence that thcy have increased priees.

\section{T'rade Boards in England.}

The British Trade Boards Act of 1909 is based on the Victorian model. It applies, at present, only to four trades-slop tailoring, paper-box making, chain-making, and lace finishing.

All the four Trade Boards appointed have now issued determinations which, however, are not all yet in full force. They all, however, raise the average wages, the inerease in the ehain-making trade amounting to from 50 per cent. to 100 per cent. A still more important result in the chain-making trade is that the reomen engaged in it have, as a result of thcir increased reages, become completely organised in a Trade Union, whereas before it was found impossible to organise them.

The main weaknesses of the British Trade Boards are as follows :

1. The Boards so far have not yet as much courage as might have been hoped, and have been too ready to listen to the plea that large increases in wages would ruin the trades concerned. Consequently, the increases, although valuable, are not altogether satisfaetory.

2. The application of the Act is too restrieted. The Board of Trade has power to extend it to other trades, but only to those in which wages are " exceptionally low" compared to other trades; thus, many trades that ought to be brought in are cxcluded merely because others are in a worse plight.

3. The Boards have insufficient power under the Act. They ought to be empowered to deal not only with wages, but, as in 
Victoria, with hours and with all the other conditions of the wage contract.

The 'Trade Boards Act is now to be extended to the following trades, the rates of wages in sections of which are exceptionally low : shirt-making, sugar confectionery-fruit preserving, jam, piekles, sauces, ete., metal hollow-ware, linen embroidcry, calendering and machine-ironing in steam laundries. 


\section{APPENDIX G. \\ AVERAGE NUMBER OF ACRES PER LABOUJER EMPLOYED ON TENANT FARMS.}

On pp. $7 *$ to 77 of the Acreage and Live Stock Returns for 1911 (Cd. 6021) are shown the total number of holdings (above 1 acre) in each county, with the average size of the holdings, also the acreage of holdings occupied by the owners, and the proportion of such acreage to the total acreage. By multiplying the first two together, the total acreage for each county is obtained, and subtracting the acreage occupied by owners, we get the total acreage of tenant farms for each eounty.

On pp. 114 to 117 of the Report on the Decline in the Agricultural Population (Cd. 3273) arc given the total number of shepherds and agricultural labourers employed in each county. Deducting a number in each case proportionate to the acreage occupied by ow iers, we get the number in eacl county of shepherds and agricultural labourcrs (added together) employed on tenant farms.

'The average number of acres for labourers is found by dividing the number of acres of tenant farms in each county by the number of labourers employed.

It should be noted that the numbers shown in $\mathrm{Cd} .3273$ are those of the 1901 Census, and these are the latest figures available, those for the last Census not having appeared when the table was compiled. The latest figures may considerably affect the results arrived at.

In ealculating the acreage, no account lias becn taken of mountain and heath land, as this is not included in the Return on pp. 74 to 77 of Cd. 6021. But as much of this land is land for which no rent or only a very small rent is charged, it was thought that for the purpose of this inquiry it might be neglected, more especially as it would be used for grazing, which would only employ comparatively few men.

\begin{tabular}{|c|c|c|c|}
\hline Counties. & $\begin{array}{l}\text { Acreage of } \\
\text { Tenant Farms* } \\
\text { (of } 1 \text { acre and } \\
\text { upwards). }\end{array}$ & $\begin{array}{l}\text { No. of } \\
\text { laboururs } t \\
\text { employed. }\end{array}$ & $\begin{array}{l}\text { No. of acres } \\
\text { per labourer. }\end{array}$ \\
\hline Bedford $\ldots$ & 217,585 & $8,18: 3$ & $26 \cdot 5$ \\
\hline Huntingrlon & 185,679 & $5,0.47$ & $36 \cdot 7$ \\
\hline Cambridge and Isle of Ely & 400,284 & 14,004 & $28 \cdot 5$ \\
\hline Suffolk $\quad \ldots \quad \ldots \quad \ldots$ & 599,634 & 22,811 & $26 \cdot 2$ \\
\hline
\end{tabular}

* Pages 74-77, Aereage and Live Stock Returns for 1911 (Cd. 6021).

+ Pages 114-117, Report on the Deeline in the Igrieultural Population (Cd. 3273). 


\begin{tabular}{|c|c|c|c|c|c|c|}
\hline \multicolumn{4}{|c|}{ Counties. } & \multirow{2}{*}{$\begin{array}{c}\begin{array}{c}\text { Acreaje of } \\
\text { Tenant Farms* } \\
\text { (of } 1 \text { acre and } \\
\text { upwards). }\end{array} \\
6: 38,111\end{array}$} & \multirow{2}{*}{$\begin{array}{c}\begin{array}{c}\text { No. of } \\
\text { labourerst } \\
\text { employed. }\end{array} \\
2-4,2.58\end{array}$} & \multirow{2}{*}{$\begin{array}{l}\begin{array}{c}\text { No. of acres } \\
\text { per labourer. }\end{array} \\
26 \cdot 3\end{array}$} \\
\hline Essex & $\ldots$ & ... & $\ldots$ & & & \\
\hline Hertford & $\ldots$ & $\ldots$ & $\cdots$ & 268,7 is & 8,911 & $30 \cdot 1$ \\
\hline Middlesex & & $\ldots$ & $\ldots$ & 76,110 & 3,322 & $22 \cdot 9$ \\
\hline London & $\cdots$ & $\cdots$ & $\cdots$ & 5,874 & 627 & $9 \cdot 3$ \\
\hline Norfolk & $\therefore$ & $\cdots$ & $\cdots$ & 921,842 & 30,077 & $30 \cdot 6$ \\
\hline I.ineolnshi & iirc & $\cdots$ & ... & $1,354,9 ; 8$ & 82,392 & 4.8 \\
\hline York, F.1 & & $\ldots$ & $\ldots$ & 626,550 & $12,4 \% 0$ & $50 \cdot 2$ \\
\hline Kent & $\ldots$ & ... & $\ldots$ & 603,993 & 27,049 & $22 \cdot 3$ \\
\hline Surrey & $\ldots$ & $\cdots$ & $\cdots$ & 177,972 & 7,051 & $2.5 \cdot 2$ \\
\hline Sussex & $\cdots$ & $\cdots$ & $\ldots$ & 5399,832 & 16,795 & $32 \cdot 1$ \\
\hline Berks & … & $\cdots$ & $\ldots$ & 267,088 & 8,020 & $33 \cdot 3$ \\
\hline Hants \& I & I. of $\mathrm{WV}$. & .... & $\ldots$ & $540,7 \div 0$ & 14,875 & $36 \cdot 3$ \\
\hline Nottinghi & in & $\cdots$ & $\ldots$ & 391,753 & 8,230 & $47 \cdot 6$ \\
\hline Leicester & $\ldots$ & $\ldots$ & $\cdots$ & 428,615 & $7,4: 32$ & $57 \cdot 6$ \\
\hline Rutland & $\ldots$ & $\cdots$ & $\ldots$ & 70,141 & 1,423 & 53.5 \\
\hline Northamp & pton & $\cdots$ & $\ldots$ & $494, \mathbf{3} 44$ & 11,217 & $4 \div \cdot 0$ \\
\hline Buckinglia & Iam & $\ldots$ & $\ldots$ & 346,126 & 9,590 & $36 \cdot 0$ \\
\hline Oxford & $\ldots$ & $\ldots$ & $\ldots$ & 352,192 & $9,83.5$ & $35 \cdot 8$ \\
\hline Warwick & $\ldots$ & $\ldots$ & $\ldots$ & 443,273 & 9,766 & $45 \cdot 3$ \\
\hline Salop & $\ldots$ & $\cdots$ & $\cdots$ & 658,671 & 11,650 & $56 \cdot 5$ \\
\hline Worcester & & $\cdots$ & $\ldots$ & 344,924 & 9,757 & $35 \cdot 3$ \\
\hline Gloucester & r... & $\ldots$ & $\ldots$ & 563,096 & 12,140 & $46 \cdot 3$ \\
\hline Wiltshire & $\ldots$ & $\ldots$ & ... & 631,729 & 14,952 & $42 \cdot 2$ \\
\hline Monmouth & & $\ldots$ & $\ldots$ & 213,407 & 2,821 & $75 \cdot 6$ \\
\hline Hereford & $\ldots$ & $\cdots$ & $\cdots$ & 400,081 & $\tau, S 09$ & $51 \cdot 2$ \\
\hline Somerset & $\ldots$ & $\ldots$ & $\ldots$ & 775,371 & 16,831 & $46^{\circ} 0$ \\
\hline Dorset & $\ldots$ & $\ldots$ & $\ldots$ & 484,372 & 10,036 & $4 \therefore \cdot 2$ \\
\hline Devon & $\ldots$ & $\ldots$ & $\ldots$ & $1,076,183$ & 18,328 & $58 \cdot 7$ \\
\hline Cornwall & $\ldots$ & $\ldots$ & $\ldots$ & 551,104 & 9,167 & $60 \cdot 1$ \\
\hline Narthumb & berland & $\cdots$ & $\ldots$ & 646,110 & 8,511 & $75 \cdot 9$ \\
\hline Dưrham & $\ldots$ & $\cdots$ & $\ldots$ & 399,300 & 5,222 & $76 \cdot 4$ \\
\hline York, N.P & & $\ldots$ & $\ldots$ & 810,946 & 10,818 & 74.9 \\
\hline York, W.I & & $\ldots$ & $\ldots$ & $1,095,978$ & 18,608 & $58 \cdot 8$ \\
\hline Cumberlar & ind & $\ldots$ & $\ldots$ & $494,75 \%$ & 6,140 & $80 \cdot 5$ \\
\hline Westmorle & land & $\ldots$ & $\ldots$ & 219.666 & 1,995 & $110 \cdot 1$ \\
\hline I.ancaster & $r \ldots$ & $\cdots$ & $\ldots$ & $7-40,327$ & 19,317 & $38 \cdot 3$ \\
\hline Chester & $\ldots$ & $\cdots$ & $\ldots$ & 495,706 & $13,6.17$ & $36 \cdot 3$ \\
\hline Derby & ... & ... & $\ldots$ & 451,108 & 6,769 & $66 \cdot 6$ \\
\hline Staflord & $\ldots$ & ... & $\ldots$ & $5-4.5,525$ & 10,s5s & $50 \cdot 2$ \\
\hline Anglesey & $\ldots$ & ... & $\ldots$ & $129,20: 3$ & 2,876 & $4 \cdot 1 \cdot 9$ \\
\hline Carnarion & & ... & $\ldots$ & $152,62-4$ & 3,026 & $50 \cdot 4$ \\
\hline Merioneth & & $\ldots$ & $\ldots$ & $141,1: 38$ & 1,778 & $79 \cdot 3$ \\
\hline Montgome & ery & $\ldots$ & $\ldots$ & $25-1,2: 38$ & 8,209 & $79 \cdot 2$ \\
\hline Denbigh & $\ldots$ & ... & $\ldots$ & $242,(630)$ & 4,095 & $59 \cdot 2$ \\
\hline Flint & $\ldots$ & $\ldots$ & $\ldots$ & $117,97 \%$ & 2,178 & $54 \cdot 1$ \\
\hline
\end{tabular}

* Pages 7.1-77, Acreagc and Live Stock Returus for 1911 (Cd. 6021). $\dagger$ Pages 114-117, Report on the Decline in the Agricultural l'opulation (Cd. 3273). 


\begin{tabular}{|c|c|c|c|c|c|c|}
\hline & Counties. & & & $\begin{array}{l}\text { Acreage of } \\
\text { Tenart Farms* } \\
\text { lof l acre a id }\end{array}$ & $\begin{array}{l}\text { No of } \\
\text { labo'ir rst }\end{array}$ & $\begin{array}{l}\text { No of acres } \\
\text { ler labouier. }\end{array}$ \\
\hline Cardigan & $\ldots$ & ... & $\ldots$ & 220,421 & 2,327 & 94.7 \\
\hline Radnor & $\cdots$ & $\cdots$ & $\cdots$ & 144,021 & 1,414 & $101 \cdot 8$ \\
\hline Brceon & $\cdots$ & $\cdots$ & $\cdots$ & 187,270 & 1,676 & $111 \cdot 7$ \\
\hline Glamoryar & & $\cdots$ & $\cdots$ & 247,596 & 3,398 & $72 \cdot 8$ \\
\hline Carmarthe & en & $\cdots$ & $\cdots$ & 388,205 & 3,192 & $121 \cdot 6$ \\
\hline Pembroke & & $\ldots$ & $\ldots$ & 273,665 & 3,157 & $86 \cdot 6$ \\
\hline Nairn & $\cdots$ & $\cdots$ & $\cdots$ & 22,852 & 585 & $39 \cdot 0$ \\
\hline Elgin or $\mathrm{A}$ & Ioray & $\cdots$ & $\cdots$ & 90,955 & 2,163 & $42 \cdot 0$ \\
\hline Banff & $\cdots$ & $\cdots$ & $\cdots$ & 144,110 & 3,156 & $45 \cdot 6$ \\
\hline Aberdeen & $\ldots$ & $\cdots$ & $\cdots$ & 586,645 & 11,711 & $50 \cdot 0$ \\
\hline Kineardin & & $\ldots$ & $\ldots$ & 107,337 & 2,405 & $44 \cdot 6$ \\
\hline Forfar & $\cdots$ & $\cdots$ & $\cdots$ & 224,757 & 5,208 & $43 \cdot 1$ \\
\hline Perth & $\cdots$ & $\cdots$ & $\cdots$ & 275,327 & 5,102 & $53 \cdot 9$ \\
\hline Claekman & nan & $\cdots$ & $\cdots$ & 12,966 & 265 & $48 \cdot 9$ \\
\hline Kinross & $\ldots$ & $\cdots$ & $\cdots$ & 24,350 & 326 & $74 \cdot 6$ \\
\hline Fife & $\ldots$ & $\cdots$ & $\ldots$ & 206,296 & 4,703 & $43 \cdot 8$ \\
\hline Linlithgov & & $\ldots$ & $\ldots$ & 54,209 & 1,122 & $48 \cdot 3$ \\
\hline Midlothiar & & $\cdots$ & $\cdots$ & 107,730 & 3,168 & 34.0 \\
\hline Haddingto & on & $\cdots$ & $\cdots$ & 97,318 & 3,460 & $28 \cdot 1$ \\
\hline Berwiek & $\cdots$ & $\cdots$ & $\cdots$ & 170,095 & 3,664 & $46 \cdot 4$ \\
\hline Roxburgh & & $\ldots$ & $\ldots$ & 154,334 & 3,263 & $47 \cdot 2$ \\
\hline Selkirk & $\ldots$ & ... & $\ldots$ & 25,417 & 578 & $43 \cdot 9$ \\
\hline Peebles & $\ldots$ & $\cdots$ & $\cdots$ & 42,772 & 726 & $58 \cdot 9$ \\
\hline Shetland & $\cdots$ & $\cdots$ & $\cdots$ & 50,132 & 249 & $201 \cdot 3$ \\
\hline Orkney & $\cdots$ & $\cdots$ & $\cdots$ & 95,294 & 1,588 & $60 \cdot 0$ \\
\hline Caithness & $\cdots$ & $\cdots$ & $\ldots$ & 104,386 & 2,040 & $51 \cdot 1$ \\
\hline Sutherlan & & $\ldots$ & $\ldots$ & 28,846 & 835 & $34 \cdot 5$ \\
\hline Ross and & Cromar & ty & $\ldots$ & 120,211 & 3,187 & $37 \cdot 7$ \\
\hline Inverness & $\cdots$ & ... & $\cdots$ & 127,286 & 3,310 & $38 \cdot 4$ \\
\hline Argyll & $\cdots$ & ... & $\cdots$ & 108,623 & 3,514 & $30 \cdot 9$ \\
\hline Bute & $\cdots$ & ... & $\cdots$ & 24,476 & 606 & $40 \cdot 3$ \\
\hline Dumbarto & & $\cdots$ & $\ldots$ & 42,269 & 1,052 & $40 \cdot 1$ \\
\hline Stirling & $\ldots$ & $\cdots$ & $\ldots$ & 95,955 & 1,934 & $49 \cdot 6$ \\
\hline Lanark & $\ldots$ & .. & $\cdots$ & 219,124 & 4,570 & $47 \cdot 9$ \\
\hline Tenfrew & $\cdots$ & ... & $\cdots$ & 75,153 & 1,828 & $41 \cdot 1$ \\
\hline Ayr & $\cdots$ & ‥ & $\cdots$ & 291,427 & 4,870 & $59 \cdot 8$ \\
\hline Dunfries & $\ldots$ & ... & $\ldots$ & $224,54.3$ & 3,795 & $59 \cdot 1$ \\
\hline Kirkeudbr & right & ... & $\ldots$ & 172,713 & 2,576 & $67 \cdot 0$ \\
\hline IVigtown & $\ldots$ & $\ldots$ & $\ldots$ & 148,706 & 3,419 & $43 \cdot 4$ \\
\hline
\end{tabular}

* Pages $\% 4-7 \%$, Acreage and Live Stock Returns for 1011 (Cd. 6021).

† Pages 114-117, Report on the Decline in the Agrieultural Population (Cd. 3273). 


\section{APPENDIX $\mathrm{H}$.}

\section{RENT PER ACRE OF TENANT FARMS.}

There seen to be no proper official statisties on this point, and certainly no recent ones. The general opinion scems to be that the average value of amricultural land in Great Britain is 20s. per acre, but of course this varies enormously in different counties and in different parts of the same eounty. Consequently, it has secmed advisable to obtain as many facts as possible as to actual rent per acre paid on different farms and on as recent dates as possible.

The following information was collected in this way :

From the Journal of the Royal Statistical Society, Vol. 55 (1892), in an article on "The Accounts of an Oxford College" :

Farm in Oxfordshire (arable, 109 acres; pasturc, 78 acres). Rent per acre in $1890,19 \mathrm{~s}$. ('Tenant paying tithe.)

Farm in valley of Upper Thames, Berkshire (2,181 acres). Rent per acre in $1890,20 \mathrm{~s}$. (College paying tithe.)

Farm near Banbury (824 acres). Rent per acre in 1890, 26s.6d. (No tithe.)

Farm near Oxford (arable, 87 acres ; pasture, 88 acres). Rent per acre in $1890,27 \mathrm{~s}$. (College paying tithe.)

Do., do. Rent per acre in 1890, 30s. (No tithe.)

Farin on a hilly slope near Bath (317 acres). Rent per acre in 1890, 24s. (Tenant paying tithe.)

Farm in Iient. Rent per acre in 1890, 16s.6d. (College paying tithe.)

From an artiele "Agricultural Depression ... its Effects on a Leading London Hospital," in the same volume :

Farm in Herefordshire $(9,1,90$ acres). Rent per acre on average of 3 years, 1889 to $1891,23 \mathrm{~s} .3 \mathrm{~d}$.

Farm in Lincoln (6,891 acres). Rent per acre on average of 3 years, 1859 to $1891,34 \mathrm{~s}$.

Farm in Essex $(8,785$ acres $)$. Rent per acre on average of 3 years, 1889 to 1891,14 s. 2 d.

From Rural England, by Sir II. Rider Haggard. He made inquiries in 27 eounties in England in 1901 and 1902 : 
WILTSHIRE.

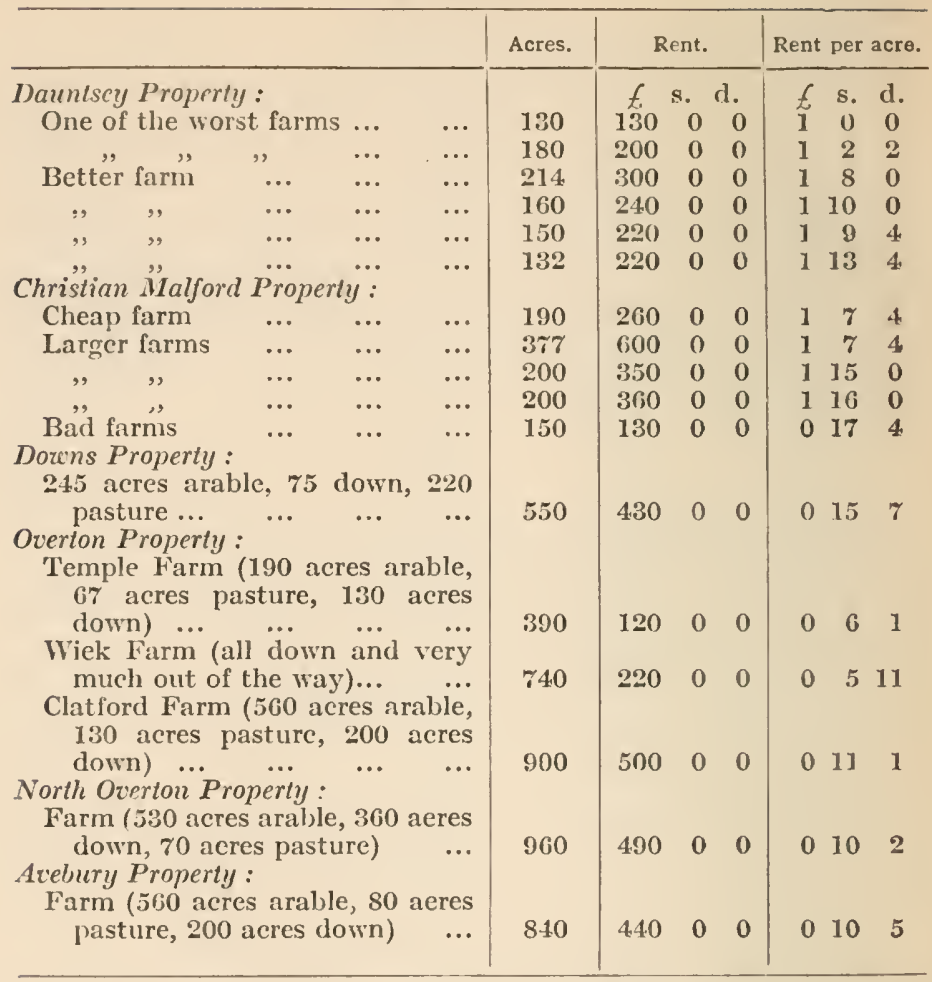

On an accompanying map the rents in Wiltshire were shown as from $5 \mathrm{~s}$. per acre for hill land to $35 \mathrm{~s}$. per acre for bottom pastures. The average per acre in one part of the county was shown as $25 \mathrm{~s}$., in another as 20s.

\section{IIANPSHIIRE.}

Rents from 21s. to 5s., tithe free. Sporting rights generally reserved. Mr. Butler, wlo had managed land in Wiltshire and Hampshire since 1882 -i.e., all his working life-put rent of ordinary land in good heart in Mampshire at about 15 s. an acre.

\section{SUSSEX.}

Rents, 20s. to 30s. per acre.

Rye Division, 12s. 6d. to $15 \mathrm{~s}$.

Map shows rent of marshland in East Sussex to go up to 40 s., hill farms from 10s. downwards. According to the map, the average would seem to be 20 s. to 30 s. 
KEnT.

Rent per acre, 30s. to $40 \mathrm{~s}$. (the latter for the best hop lands).

Wye and Romney Marsh, average 20 s.

Marshlands, 20s. to 25s.

\section{Devonsmine.}

Average rent, 25s. per aere.

Farms of about 70 aeres on the borders of Dartmoor (good arable and pasture) at a rent of $10 \mathrm{~s}$. to $14 \mathrm{~s}$. an aere.

In the South Hammers district Mr. Yosper estimated " that from $25 \mathrm{~s}$. to $35 \mathrm{~s}$. per aere would be a fair average for best mixed land of, say, half pasture and half arable, and from 15s. to 25s. for the poor ordinary lands, aceording to quality."

A farm of 400 aeres between Honiton and Exeter was rented at a little over $28 \mathrm{~s}$. an acre.

Mr. Edgar Dudley, of Plymouth, said he had 15 years' experienee in the West of England, and he put the present average annual rental value of agricultural land in Devonshire at 20s. an acre.

A large landowner put the average rental of best lands at $\mathbf{2 5}$., and second-class lands at $17 \mathrm{~s}, 6 \mathrm{~d}$. per acre.

\section{Sonersfet.}

Rents (according to the map), 20s. to 50s. an acre.

Average rents, $20 \mathrm{~s}$. to $25 \mathrm{~s}$.

Vale lands round Taunton, 30 s, to 40 s. an acre.

Near Yeovil nice mixed grass holdings of 60 to 120 aeres were rented at $45 \mathrm{~s}$. to $60 \mathrm{~s}$.; mixer farms of 120 to 160 acres, $35 \mathrm{~s}$. to $45 \mathrm{~s}$. per acre; large mixed farms, 20s. to $35 \mathrm{~s}$. per aere.

Haselbury district, a farm of 534 aeres was rented at 22s. $6 \mathrm{~d}$. per acre. In this district even adjoining fields vary very muel in value; thus some lying close to this farm were worth only $10 \mathrm{~s}$. an acre.

\section{Dorsetsinte.}

Rents, 10s. to 50s., or in valleys even 60 s. per aere.

\section{HEREFOIDSHIRT.}

Rents, 10s. to 20 s. per aere. Good land, 25s. to 32s. per acre

\section{WorCESTERSIIIRE.}

Rents, 1Ss. to 30s. per acre.

Rent for small holdings is much higher than for large farms. Thus, in the Bewdley distriet a tenaney of 40 aeres was let at 50 s. the acre, while next to it lay one of 250 aeres of similar land that brought in but 20s. the acre. Another small holding of 24 
acres of poor land was let at 33s. per acre, whereas a large neighbouring farm of between 300 acres and 400 acres realised but 12s. or 13s. an acre.

N.B.-There is so much demand for small holdings that the rents of these are often put up much too high. Rider ILaggard suggests that County Councils should take large parcels of land and let out in small holdings at proper rents.

\section{Glovcestershime.}

Freehold farm, cottages and land, 307 acres, rent $13 \mathrm{~s}$. per aere.

Two freehold farms, with cottages, buildings and land, 980 acres, rent 5s. 6d. per acre.

Freehold farm, with cottages and land, 219 acres, rent 10s. per acre.

$\Lambda$ large area of the Cotswold land is let at rents varying from 5 s. to 10 s. the acre.

\section{WARWICKSHIRE.}

Near Nuneaton the average rent is $1 \%$ s. $6 \mathrm{~d}$. per acre.

Between Coventry and Birmingham, heavy arable land, rents 10s. to $15 \mathrm{~s}$. per acre.

Kienilworth, 20s. to 29s. per acre.

Near Redditch the average rent is 25s. Dairy land, 20s. to $60 \mathrm{~s}$.

Near Alcester, rents 13s. down to 2s. $6 \mathrm{~d}$

Between Warwiek and Stratford-on-Avon, 15s. to 20 s.

Southern end of county, rents $17 \mathrm{~s}$. to $27 \mathrm{~s}$., and $35 \mathrm{~s}$. to $4.0 \mathrm{~s}$.

The following are the rents of 5 farms on the Earl of Camperdown's estate, their average size being just over 200 acres :

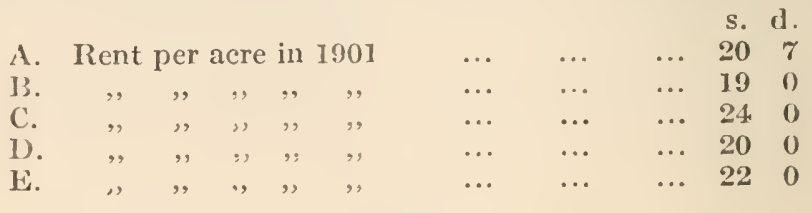

\section{Sirropsirre.}

Northern part.-Hill land rents, $15 \mathrm{~s}$. ; mixed farm rents, 20s.; rents (best farms), $26 \mathrm{~s}$. to $35 \mathrm{~s}$.; average, $20 \mathrm{~s}$. to $30 \mathrm{~s}$.

Southern part.-Mixed farm rents, 21 s. to 26 s.; pasture farm rents, 35s.

The gross rental of a large and typical Shropshire estate of 7,000 acres was, in $1901,18 \mathrm{~s}$. an aere. It is an instructive fact that almost the entire loss (i.e., from the previous gross rental of 23s. per acre) is due to the reduced letting value of farms over 50 aeres, those under 50 acres having practically held their own as a source of income. This estate may be divided into threc 
classes-bottom lands, which fetch about 21s. an acre; hill-side farms, estimated at 12s.; and hill-top sheep runs, worth 5s. an acre.

\section{Essex.}

Saffron Walden, rents 5s. to 20 s.

Near River Stour, 40s. to 60s.; high land close by, 5 s. to $15 \mathrm{~s}$.

Epping, 11s. to 15s. 6d.; pasture rent up to $40 \mathrm{~s}$.

Maldon, $15 \mathrm{~s}$. to $5 \mathrm{~s}$.

Near Southend, rents 6s. to 40 s.

Chelmsford, 12s. to $25 \mathrm{~s}$.

Hertfordsuire.

North, near Royston, chalky land, 15s.; pasture rents, 25 s. Near Buntingford, 10s. to 15s.

Near Hitehin, average rent, $17 \mathrm{~s}$.

Western side, heavy hill land, 7 s. 6d. to 20s. ; low land, medium land, $17 \mathrm{~s}$. to $30 \mathrm{~s}$.

Near St. Albans, 20s.

Near Hatfield, rents on farms near rail, $26 \mathrm{~s} . ;$ other rents, $10 \mathrm{~s}$. to $15 \mathrm{~s}$.

Near Watford, poor arable, 10s. ; pasture, 30s. to 40 s.

Near Rickmansworth, 20s, to 30s.

\section{Cambridgesinire.}

Near Wisbech, rents of uplands, 12s. to 25s.; fen, 15s. to $30 \mathrm{~s}$. Eastern side, 20s.

Southern side, 7s. to $20 \mathrm{~s}$.

Rents, 20s. to 40s.

\section{HunTingdon}

OxForn.

Near Bicestcr, average rents, $18 \mathrm{~s}$.

Néar Banbury, average rents, 24 s.

Near Henley, average rents, 18s. (hill land).

Near Rockingham, 35s, to 40 s.

\section{Northampton.}

Near Market Harborough, up to 36 s.

Near Nortliampton, 20s. to $36 \mathrm{~s}$.

Near Brackley, 15s. to $25 \mathrm{~s}$.

\section{LiNCOLNSHIRE.}

Near Banks of River Humber, 40s. to 50s.

Near Brigg, 20s. to 25s.

Near Caistor, 7s. 6d., 9s., 11s., and 12s.

Near Saltfleet, 40s. to 50s.

Between Lincoln and Market Rasen, 5s. to 10 s.

South Lindsey or Horncastle district, 20s. to 60s

Generally in Lincolnshire the rents vary from 10 s, to 30 s. 


\section{Leicester and Rutland.}

Along the northern border of Leieestershire the rents of some farms go up to $4.0 \mathrm{~s}$. an acre, but the average is $30 \mathrm{~s}$.

Near Loughborough, rents 15s. to 25s. per acre.

Near Leicester the average rent is $23 \mathrm{~s}$., but in the case of farms of under 100 aeres the rent goes up to 40 s.

South-east of Uppingham, in the valley of the River IVelland, rents from $35 \mathrm{~s}$. to $40 \mathrm{~s}$.

In Rutlandshire the average rent is from $15 \mathrm{~s}$. to $30 \mathrm{~s}$.

\section{Noterngilam.}

Bassetlaw district, rents $18 \mathrm{~s}$. to $23 \mathrm{~s}$.

Near Mansfield, rents 20s.

Near Newark, rents 60 s.

Near Southwell, rents $18 \mathrm{~s}$. to $35 \mathrm{~s}$. in the case of farms of under 100 acres, and $12 \mathrm{~s}$. to $25 \mathrm{~s}$. in the ease of farms of 200 acres and over.

In the Vale of Belvoir, rents 35s. to $40 \mathrm{~s}$.

North-east of Newark, rents 10s. to $25 \mathrm{~s}$.

Yorksime, Nortil ANd East Ridings.

Fast of Northallerton, rents 12s. to $20 \mathrm{~s}$.

Near 'I'hirsk, rents 20s. to 30s.

North of the River Derwent, the average rent is $27 \mathrm{~s}$. an acre.

South of the River Derwent, the average rent is $20 \mathrm{~s}$. to $27 \mathrm{~s} .6 \mathrm{~d}$.

In the Buekrose district, rents 12s. to 24s.

In the Holderness district, rents $16 \mathrm{~s}$. to $25 \mathrm{~s}$.

In the Howdenshire distriet, rents $20 \mathrm{~s}$. to $35 \mathrm{~s}$.

Near North York Moor, rents 17s. to 40s.

In the Richmond district, rents $10 \mathrm{~s}$. to $25 \mathrm{~s}$.

Yorksime, IVFst RIDING.

In the Ripon district, rents of best land 30s., and of middle land 2 ?s.

Near Ripley and Harrogate, rents $16 \mathrm{~s}$. to $30 \mathrm{~s}$.

In the Otley district, rents $22 \mathrm{~s}$. to $30 \mathrm{~s}$. for the best land.

Between Leeds and Selby, rents 18s. to 30 s.

\section{SuFrolk.}

Near Beccles and Lowestoft, rents $40 \mathrm{~s}$. to $60 \mathrm{~s}$.

In the Valley of the River Waveney, rents up to $10 \mathrm{~s}$.

Eye Division, rents 10 s. to $17 \mathrm{~s}$, and 15s. to 20s., good pasture 20s., poor pasture 5s.

Near Bury St. Edmunds, rents $7 \mathrm{~s} .6 \mathrm{~d}$. to $20 \mathrm{~s}$.

Near Long Melford, rents 6s. to 20s.

Near Woodbridge, rents $7 \mathrm{~s}$. to $25 \mathrm{~s}$.

\section{NorfolK.}

Near IVells, salt marshes, rents 20s. $1050 \mathrm{~s}$.

Near Castle Rising, rents 5s, to 20s. 
In the Valley of the Great Ouse, rents up to 40 s.

Near Fakenham, rents 10s. to 20s.

Near East Dereham, rents about $15 \mathrm{~s}$.

Near Downham, rents 17s, 6d.

Between Holt and North Walsham, rents 18s, to 25s.

Near North Walsham on the coast, rents 80 s. to $10 \mathrm{~s}$.

Between Attleborough and Downham, rents 7s. 6d. to 15s,

Near Buckenlam, rents 10s, to 20s.

Near Loddon, rents 12s. and 20s. to 30s.

Some information as to rental values may be obtained from an article in Vol. 70, for December, 1907, of the Journal of the Royal Statistical Society. It is by R. J. Thompson, and is entitled "An Inquiry into the Rent of Agricultural Land in England and Wales during the Nineteentlı Century."

On p. 596 he gives a table showing that for 399,013 acres distributed over England the average rent per acre in 1899 to 1900 was $20 \mathrm{~s}$. On the whole area of 482,000 acres, for which he has particulars for that year, the average rent works out at 22s. 2d. per aere.

On p. 612, Appendix A. The average rent per acre of agricultural land on certain estates in Lincoln, Hereford, Fssex, and North Wales in 1900 , of which the total acreage was 71,469 , was 14s. 7 d.

Appendix B. The average rent per acre of agricultural land on certain estates in Lincoln, Hereford, Buckinghamshire, Bedfordshire, Cambridge, Essex, and North Wales in 1900, of which the total aereage was 119,178 , was $17 \mathrm{~s} .2 \mathrm{~d}$.

On p. 615 arc given the rents of certain individual farms, as follows :

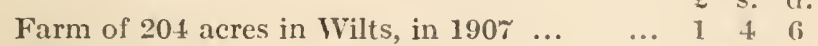

Farm of 225 acres in Norfolk, in $1905 \quad \ldots \quad 0 \quad 14 \quad 3$

Four typical farms in the South Midlands:

\begin{tabular}{|c|c|c|c|c|c|}
\hline & & & & & $\begin{array}{l}\text { nt per a } \\
\text { s. d. }\end{array}$ \\
\hline Farm C, 359 acres & $\ldots$ & $\ldots$ & $\ldots$ & $\ldots$ & 369 \\
\hline Farm D, 122 acres & $\ldots$ & $\ldots$ & $\ldots$ & $\ldots$ & 164 \\
\hline Farm E, 417 acres & $\ldots$ & $\ldots$ & $\ldots$ & $\ldots$ & 150 \\
\hline Farm F, 467 acres & $\ldots$ & $\ldots$ & $\ldots$ & $\ldots$ & 1711 \\
\hline
\end{tabular}

Further information as to rental values may be obtained from the last Report of the Commissioners of His Majesty's Woods, Forests, and Land Revenues, dated June 27th, 1911. 
On p. 38, Appendix No. 2, there is a list of holdings and farms in different counties, giving the acreage and the rent paid, as follows :

BEDForD.

A smallholding containing 30 acres

A smallholding containing 5 acres

Camibridge.

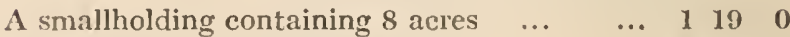

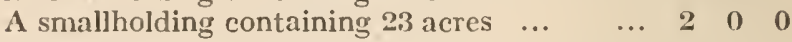

Cinester.

A smallholding containing $12 \frac{1}{8}$ acres ... about $\quad 0 \quad 15 \quad 4$

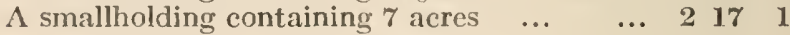

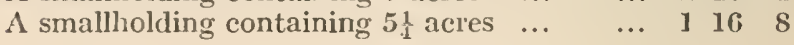

Gloucester.

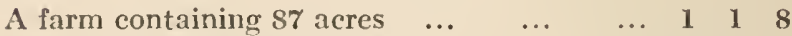

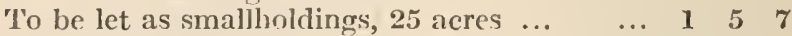
$\begin{array}{lllllll}\Lambda \text { farm containing } 207 \text { acres } & \ldots & \ldots & \ldots & 1 & 4 & 1\end{array}$

Lancaster.

A smallholding containing 12 acre

$\ldots \quad 1118$

IAINCOIN.

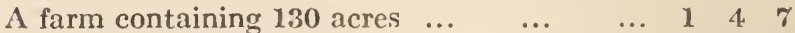

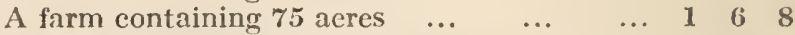

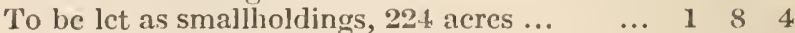

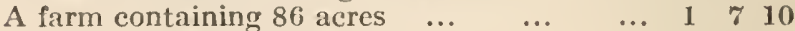

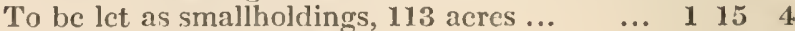

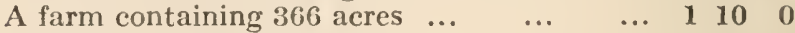

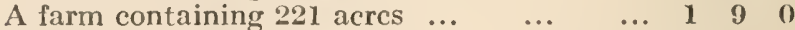

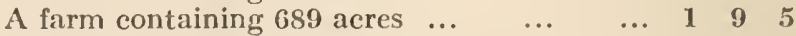

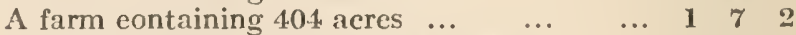

A smallholding containing $10 \frac{1}{2}$ acres ... $\quad \ldots \quad 1 \quad 10 \quad 5$

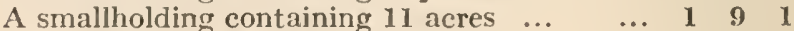

A smallholding containing $10 \frac{1}{2}$ acres $\ldots . \quad \ldots \quad \ldots \quad 1 \quad 10 \quad 5$

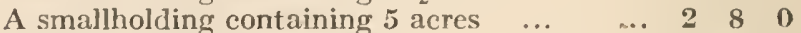

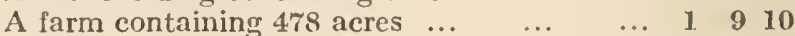

NORFOI.K.

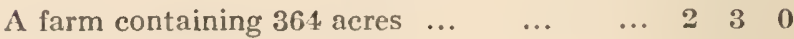

WiLTs.

A smallholding containing 7 acre

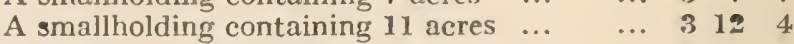

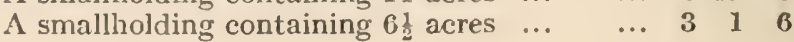


Yorks. \& s. d.

A smallholding containing $10_{1}^{3}$ acres ... $\quad \ldots \quad$ ] 17 :

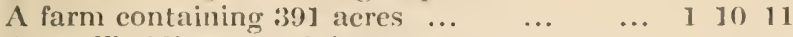

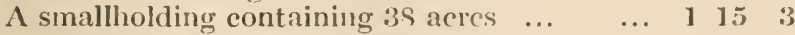

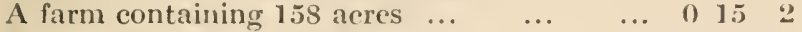

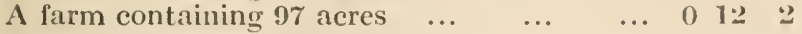

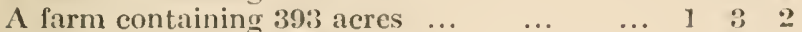

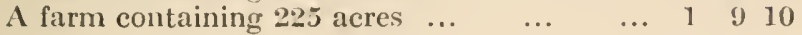




\section{APPENDIX I.}

COST OF BUILDING IN 1911 AND 1913.*

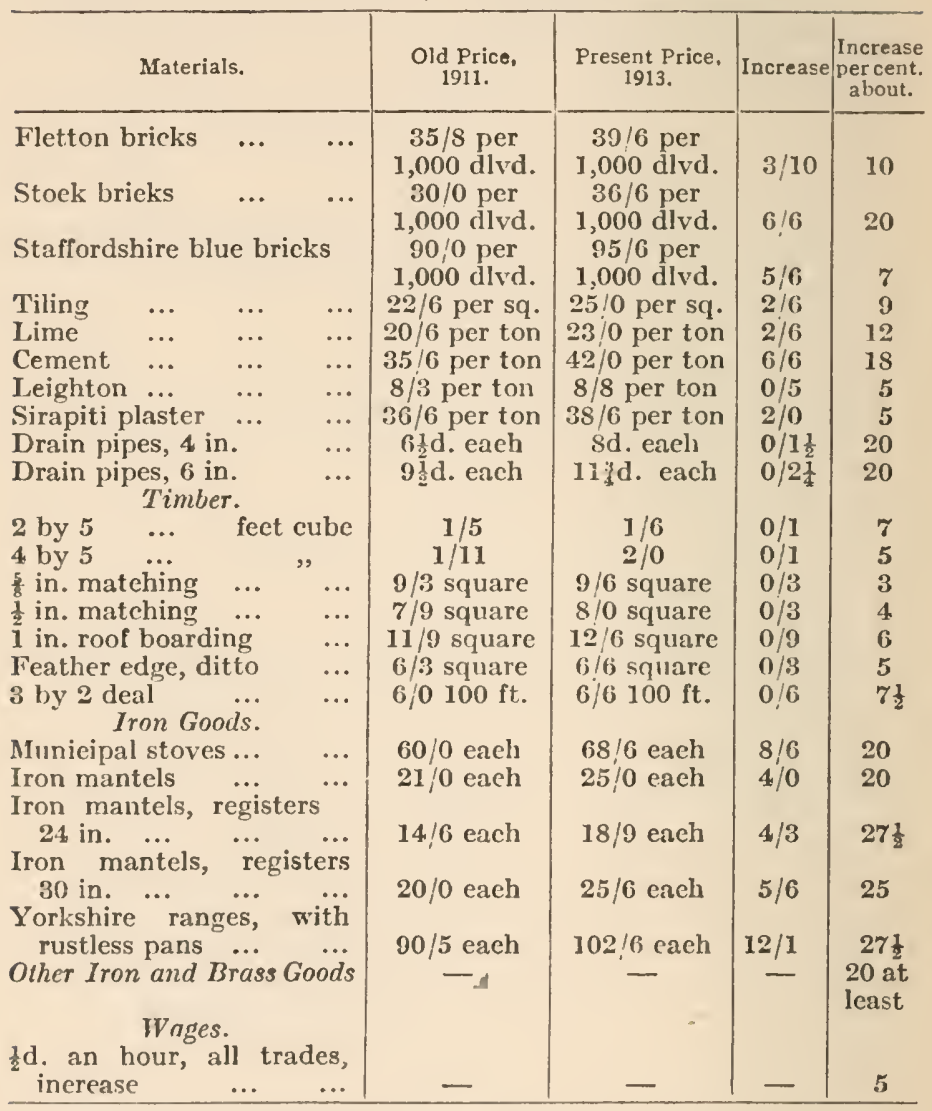

* These are taken from aetual estimates tendered in a village 3 miles from a station, and $\mathbf{2 5}$ miles from London. 


\section{APPENDIX J.}

\section{MENDEI.ISM AND AGRICULTURE.}

Extract from article, "Applied Heredity," by R. C. Punnett, M.A., in "IIarper's Monthly Magazine," December, 1908.

... So long ago as 1890 the National Association of British and Irish Millers called attention to the faet that the quality of English wheats had deteriorated. For milling purposes the foreign article with its strong glutenous grains was found to be greatly superior, and English wheats were selling at 28s. 6d. a quarter, while Manitoba hard was fetehing 35s. The National Association endeavoured to interest the agricultural societies in the question, but found that they were more or less resigned to this unsatisfactory state of things, and despaired of conpeting with the superior quality of the foreign wheat. Indced, many declared that grain of the highest quality could not be grown profitably in Great Britain. At this point the Association took a wise, and, for England, a courageous step. They decided to provide the funds for experimental research, and in 1900 Professor Biffen of the Cambridge University Agricultural Department started his remarkable series of cxperiments. It was just at the time of the rediseovery of Mendel's paper. Thanks to Professor Bateson, the extreme importanee of that paper was at once recognised in Cambridge, and Professor Biffen organised his work upon Mendelian lines. He collected together all the varieties he could lay hands on, and by numerous crossing tests he laid the foundations of an accurate knowledge of the various unit characters that occur in wheat. Hc found the beardless character to be dominant to beardlessness, rough chaff dominant to smooth, red grain to white grain, thick stem to thin stem, and so on. Early,and late ripening behaved as a Mendelian pair of characters, as also did heavy as opposed to poor cropping capaeity. Professor Biffen's analysis further revealed Mendelian heredity in two eharacters of such importance as to deserve special mention. We have already seen that the poor quality of English wheat is due to poverty of glutenous matter. The grain is too starehy, and requires the admixture of a considerable amount of glutenous "strong" foreign wheat to give flour which will bake into a presentable loaf. Professor Biffen has been able to slow that the highly glutenous grain is dominant to the starchy one. With this knowledge he lias been able in a few years to produce a wheat combining the large eropping eapacity of English wheat with the high gluten content of a foreign varicty.

But the most important and the most fascinating of all Professor Biffen's experiments concern the inheritance of an entirely different character. In all countries the most serious enemy of the wheat farmer is rust. Early in their growth the plants are attacked by a parasitic fungus, whose presence is rendered con- 
spicuous by an abundant outbreak of reddish-ycllow pustules all over the foliage. In eertain seasons and with ecrtain varieties the outbreak may be so severe as to very greatly diminish the yicld of grain. In the bad rust year of 1891 the loss due to this cause in I'russia alone was calculated at over $\$ 20,000,000$, while a well-known authority estimates that the average loss from rust to the wheat erops of the world would not be eovered by $£ 100,000,000$. No prophylaetic against the disease has been diseovered, and it is recognised that the only way to avoid it is to make use of varieties which are naturally immune. Unfortunately the few such varieties that exist are in other respects poor and unprofitable to grow.

Professor Biffen began his experiments by crossing a varicty peculiarly subject to the attaeks of yellow rust with an immune variety. The hylorids produced were all severely attacked by rust. In the following year such seed as could be collected from these plants was sown. The greater number of the resulting plants were much rusted, but some were entirely free from the disease, though growing up in the elosest contact with their rusty brethren. It was found on counting that the immune plants formed almost exactly a quarter of the total number. In other words, the experiment proved susceptibility and immunity to be a pair of liendelian characters, and consequently within the control of the hrecder to combine with other characters aceording as he pleased. The faet that resistance to yellow rust is a unit character exhibiting Mendelian inheritance makes it a simple matter to transfer it to wheats which are in every way desirable exeept for their suseeptibility to rust. From the knowledge gained through his experiments Professor Biffen has been able to build up wheats combining the large yicld and excellent straw of the best English varieties with the strength of the foreign grain, and at the same time quite immune to yellow rust. During the present year several acres of such wheat coming true to type were grown on the Cambridge University Experimental Farm, and when the quantity is suffieient to be put upon the market, there is no reason to doubt its exerting a considerable influenee on the agricultural outlook.

Besides the work on wheat, experiments have been undertaken with barley. As with the wheats, there are varieties of barleys witl glutenous and others with highly starchy grains. The more starch a barley contains, the more valuable it is for malting purposes. Since Professor Biffen las been able to demonstrate that with harley, as with wheat, starehiness is recessive to glutenous quality, it slould be an easy matter in the future to associate the starehy character with other valuable properties in barleys.

Nor is the work at Cambridge confined to plants. A start has been made will the object of investigating the inheritance of horns and of face colour in sheep, and Professor Wood has been 
able to show that both these characters are inherited upon Mendelian lines. In this way he has been able to combine the hornless eharacter of the black-faced Suffolk with the white face of the horned Dorset. Sinilarly, Professor Spillman has addueed evidence to show that the polled charaeter in eattle is dominant to the horned state, thus making it possible to dehorn painlessly any breed of eattle where this is thought desirable. . . .

[The Cambridge wheat above referred to is named "Little Joss," and is now grown widely in the Eastern Counties. 'The average yield over a series of years appears to be about 4 per cent. in exeess of "Square Head's Master," which it replaces. The University Farm sells it for seed at 60s. a quarter, which compares with $35 \mathrm{~s}$. or $4.0 \mathrm{~s}$., the priee of ordinary seed wheat. This result is valuable, though perhaps the anticipations of 1908 given above have not been completely realised.-H. D. H.] 


\section{APPENDIX K.}

\section{EXTRACT FROM ARTICLES OF ASSOCIATION OF THE' AGRICULTURAL ORGANISA'TION SOCIETY.}

13. (1) The first Governors shall eonsist of the subseribers to the Society's Memorandum of Association (who have already been nominated for this purpose by the Board of Agriculture and Fisheries and the Development Commissioners jointly), and also such other persons (being or beeoming within one month after their appointment members of the Society) as may from time to time be appointed by the said bodies, who make appointments under this clause in such numbers, and at such times, as they think fit. The first Governors shall remain in office until the first ordinary general meeting of the Society held after the first day of April, 1914. Any vacancy in the Governors shall be filled by a member to be appointed by the said bodies.

(2) The Governors other than the first shall, subject to the provisions hereinafter contained, consist of

(a) Eighteen Governors to be elected in manner hercinafter defined.

(b) Twelve Governors to be appointed by the Board of Agrieulture and Fisheries.

(c) Two Governors to be appointed by the County Couneils' Association.

(d) Two Governors to be appointed by the eo-operative Union.

(e) Two Governors to be co-opted by the Governors.

Provided that all Governors shall be nembers of the Society at the date of their election, appointment or co-optation or shall become members within one month after such date.

(3) The Governors shall have power, with the consent of the general meeting, to increase or reduee the number of Governors other than the first, but so that the numbers of the Governors shall not at any time be more than sixty, and to provide for their election in manner hereinafter defined, or their appointment by the l3oard of Agriculture and Fisheries, or their co-optation : provided always that on any such increase the number of Governors to be elected, and the number to be appointed by the Board of Agriculture and Fisheries, shall not be less than onehalf and one-third respectively of the total number. 


\section{APPENDIX L.}

EXPORTS OF DAIRY PRODUCE TO UNITED KINGDOM FRON DENMARK AND FIRANCE, 1805-1912.

(Compiled froin Annual Stalements of Trade of United Kingdom with Foreign Countries and British Possessions.)

From Denmark.*

Butter and cheese $=$ ewts.

Eggs $=$ grt. hundreds.

\begin{tabular}{|c|c|c|c|c|c|}
\hline \multicolumn{3}{|c|}{ Year. } & Cheese. & Butter. & Eggs. \\
\hline $1895 \ldots$ & $\ldots$ & $\ldots$ & - & $1,162,770$ & $1,279,013$ \\
\hline $1896 \ldots$ & $\ldots$ & $\ldots$ & - & $1,228,784$ & ]$, 566,623$ \\
\hline $1897 \ldots$ & $\ldots$ & $\ldots$ & - & $1,33 \cdot 1,726$ & $1,748,800$ \\
\hline $1898 \ldots$ & $\ldots$ & ... & - & $1,465,030$ & $2,019,508$ \\
\hline $1899 \ldots$ & $\ldots$ & $\ldots$ & - & $1,430,052$ & $2,266,030$ \\
\hline $1900 \ldots$ & $\ldots$ & ... & - & $1,486,342$ & $2,438,858$ \\
\hline $1901 \ldots$ & $\cdots$ & ... & - & $1,597,186$ & $3,019,414$ \\
\hline $1902 .$. & $\ldots$ & ... & - & $1,703,032$ & $3,518,212$ \\
\hline $1903 \ldots$ & $\ldots$ & $\ldots$ & - & $1,7 \approx 1,6: 54$ & $3,851,557$ \\
\hline $1904 \ldots$ & $\ldots$ & ... & - & $1,708,619$ & $3,602,326$ \\
\hline $1905 . .$. & $\ldots$ & ... & - & $1,630,363$ & $3,858,135$ \\
\hline $1906 \ldots$ & $\cdots$ & $\cdots$ & - & $1,675,761$ & $3,823,942$ \\
\hline $1907 \ldots$ & $\ldots$ & ... & - & $1,818,811$ & $3,800,376$ \\
\hline $1908 \ldots$ & ... & $\ldots$ & - & $1,800,160$ & $3,787,670$ \\
\hline $1909 \ldots$ & ... & $\ldots$ & - & $1,764,027$ & $3,428,200$ \\
\hline $1910 \ldots$ & $\ldots$ & $\ldots$ & 一 & $1,726,091$ & $3,647,139$ \\
\hline $1911 \ldots$ & $\cdots$ & $\ldots$ & 一 & $1,707,178$ & $3,992,986$ \\
\hline $1912 \ldots$ & $\cdots$ & $\ldots$ & - & $1,618,048$ & $3,623,815$ \\
\hline
\end{tabular}

* Including Faröe Islands; also includes Iceland and Greenland prior to 1901 .

From France.

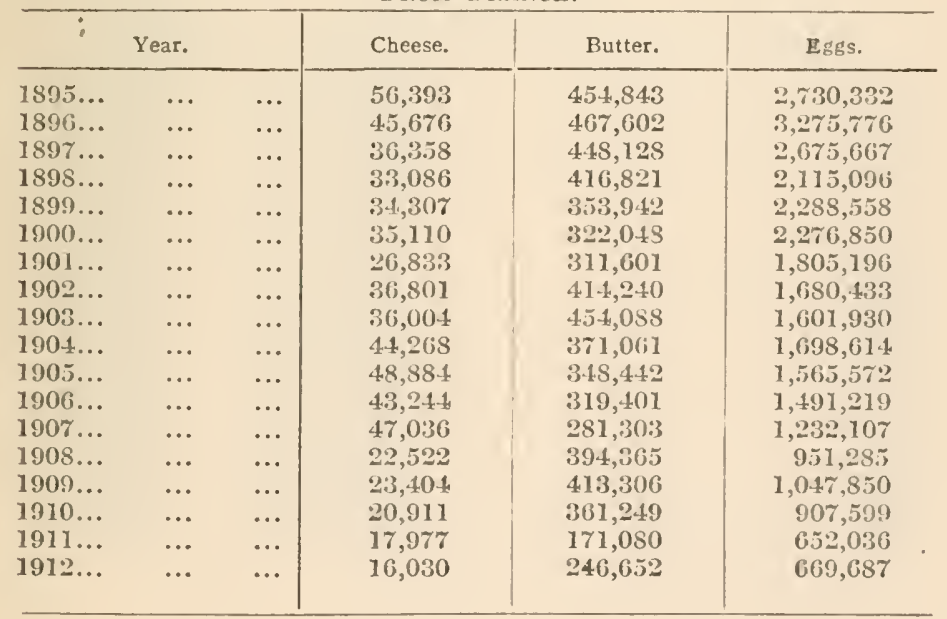




\section{DAIRY PRODUCE EXPORTED FROM DENMARIK AND} FIRANCE (TOTAL AMOUNT EXPORTED), 1S97-1911.

Compiled from (Annual) Stat. Abstract for the Principal and other Foreign Countries.

1 kilogramme $=2 \cdot 204 \mathrm{lb}$. avoirdupois (French and Danish). 1 pund (Danish) $=1 \cdot 102 \mathrm{lb}$. avoirdupois.

From France.

\begin{tabular}{|c|c|c|c|c|c|}
\hline \multicolumn{3}{|c|}{ Year. } & Cheese. & Butter. & Eggs. \\
\hline $1897 \ldots$ & $\cdots$ & $\cdots$ & $\begin{array}{l}\text { Irilog. } \\
6,4,46,000\end{array}$ & $\begin{array}{c}\text { Kilog. } \\
27,918,000\end{array}$ & $\begin{array}{l}\text { Kilog. } \\
13,854,000\end{array}$ \\
\hline $1898 \ldots$ & ... & $\ldots$ & $6,556,000$ & $24,980,000$ & $10,131,000$ \\
\hline $1899 \ldots$ & $\ldots$ & $\ldots$ & $7,8: 36,000$ & $2 \cdot 2,283,000$ & $9,918,000$ \\
\hline $1900 \ldots$ & $\ldots$ & $\ldots$ & $8,877,000$ & $20,257,000$ & $10,139,000$ \\
\hline $1901 \ldots$ & $\ldots$ & $\ldots$ & $8,072,000$ & $19,554,000$ & $9,312,000$ \\
\hline $1902 \ldots$ & $\ldots$ & $\ldots$ & $9,319,000$ & $24,4: 39,000$ & $8,039,000$ \\
\hline $1903 \ldots$ & $\cdots$ & $\cdots$ & $10,487,000$ & $27,086,000$ & $8,016,000$ \\
\hline $1904 \ldots$ & $\ldots$ & $\ldots$ & $9,395,000$ & $22,608,000$ & $10,051,000$ \\
\hline $1905 \ldots$ & $\ldots$ & $\ldots$ & $10,036,000$ & $22,584,000$ & $8,731,000$ \\
\hline $1906 \ldots$ & $\cdots$ & $\cdots$ & $10,006,000$ & $17,829,000$ & $8,412,000$ \\
\hline $1907 \ldots$ & $\ldots$ & $\ldots$ & $11,605,000$ & $15,716,000$ & $5,580,000$ \\
\hline $1908 \ldots$ & $\cdots$ & $\ldots$ & $11,010,000$ & $19,936,000$ & $7,924,000$ \\
\hline $1909 \ldots$ & $\ldots$ & $\ldots$ & $11,840,000$ & $23,253,000$ & $7,848,000$ \\
\hline $1910 \ldots$ & $\ldots$ & $\ldots$ & $11,413,000$ & $21,967,000$ & $6,699,000$ \\
\hline $1911 \ldots$ & ... & ... & $10,905,000$ & $12,804,000$ & $5,357,000$ \\
\hline
\end{tabular}

From Denmark.

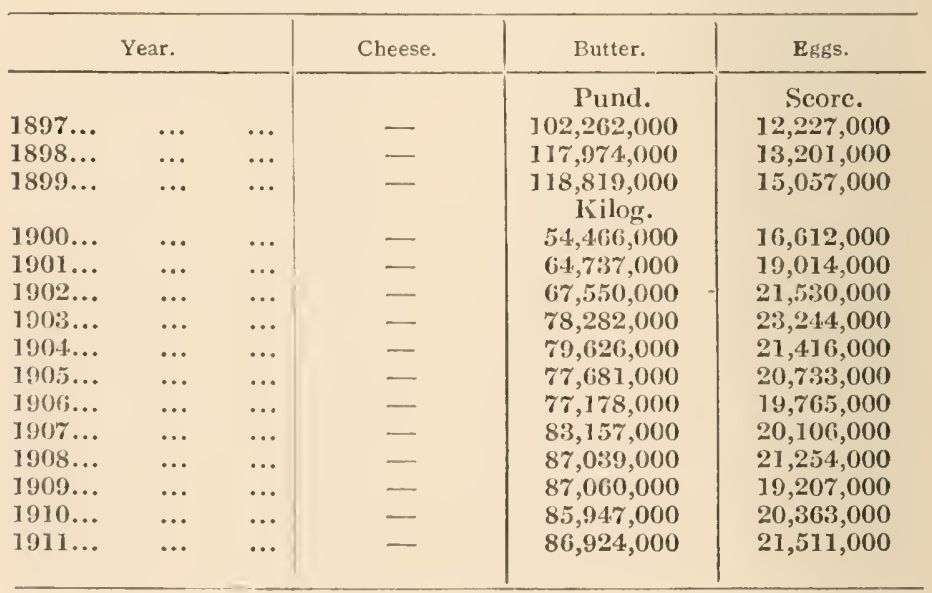




\section{APPENDIX M.}

Summary of Subventions to Local Authorities 1912-13, taken from "Finance Accounts of United Kingdom for financial year ended March 31st, 1913."

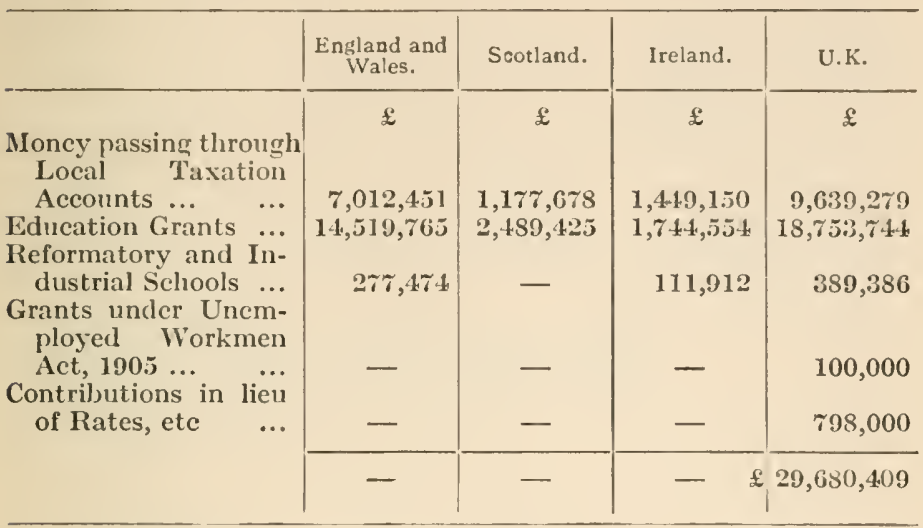

The sums passing through Local Taxation Accounts were as follows :

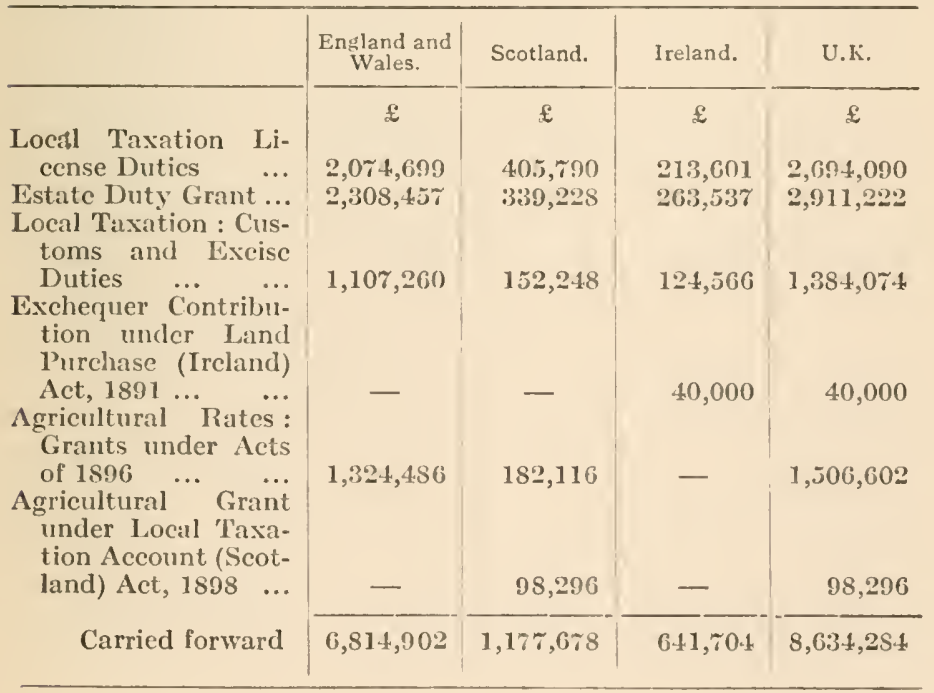




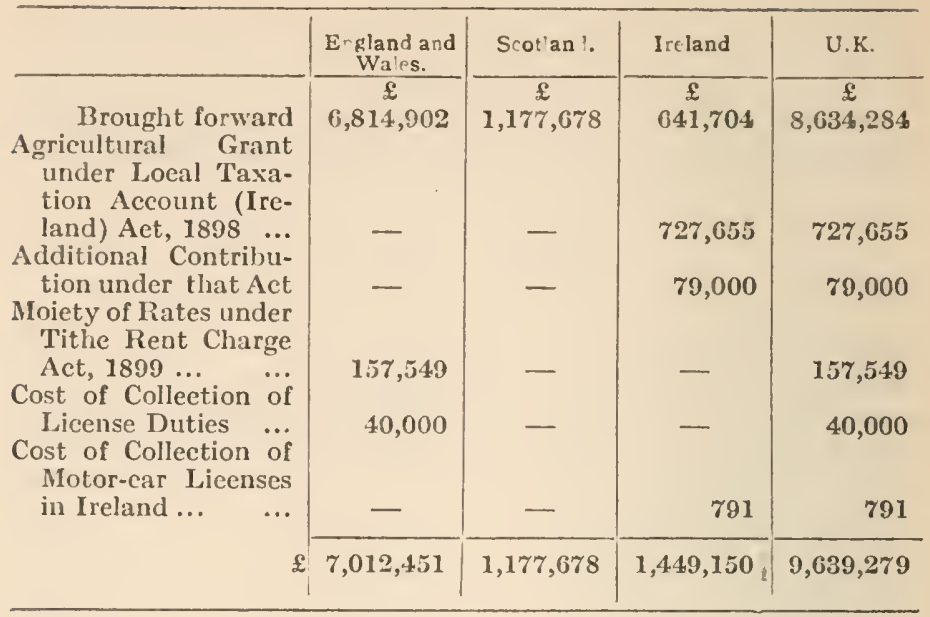




\section{BIBLIOGRAPHY}

\section{HISTORY.}

Connetт, Wm. Rural Rides (1831-32). Reeves, 1894. 2 vols. 12s. 6 d.

Col.I.Ings, Jesse. Land Reform (Occupying Ownership, Peasant Proprictary, and Rural Fdlucation). Longmans, 1908. 2s.6d. net.

Curtlis, W. H. R. Short History of English Agriculture. Clarendon Press, 1909. 6s. 6d. net.

De Coulanges, F. Origin of Property in Land. Sonnenschein, 1891. 2s. 6d.

Dunlop, Jocelyn O. The Farm Labourer; the IIistory of a Modern Prollem. Unwin, 1913. 7s. 6d. net.

Garnier, R. M. Annals of the British Peasantry. Sonnenschein, 1895. 10 s. 6d.

History of English Landed Interest. Sonnenschein, 1892-4. $21 \mathrm{~s}$.

Goume, G. L. The Village Community. Walter Scott, 1890. 3s. 6 d. net.

Gonner, E. C. K. Common Law and Enclosures. Macmillan, 1912. 12s.

Hammond, J. L. and B. The Village Labourer. Longmans, 1912. 9s.

Hasbacit, Dr. W. IIistory of English Agricultural Labourer. King \& Son, 1908. 7s. 6d. net.

Joinson, A. H. Disappearance of the Small Landholder (Ford Lectures). Clarendon Press, 1909. 5s. net.

Levy, Prof. Hermann. Large and Small Holdings. Cambridge Press, 1911. 10s. 6d. net.

Rogers, J. E. T. Six Centuries of Work and Wages. Sonnenschein [1885], 1894. 10s. 6d. net, obtainable at 4s. 6d. net ; abridged edition, 1895, 2s. 6 d. net.

History of Agriculture and Prices (1259-1793). Oxford University Press, 1866-1902. 6 vols. £9 net.

Economic Interpretation of IIistory. Unwin [1888], 1894. 2s. 6d. net.

Serвони, F. The English Village Community, examined in relation to the Manorial and Tribal Systems. Longmans, 1884. 12s. 6d. net.

Slater, Gilbert. The English Peasantry and the Enclosure of Common Fields. Constable, 1907. 10s. 6d. net.

Tawney, R. H. The Agrariun Problem in the Sixteenth Century. Longmans, 1912. 9s. net. 
Vinogradoff, P. Villeinage in England. Oxford University Press, 1892. $16 \mathrm{~s}$.

Grozth of the Manor. Sonnensehein, 1906. 10s. 6d.

Youxg, Artiunr. Six Months' Tour throught the North of England, $17 \tau 0-71$. Out of print.

\section{AGRICULTURAL REFORI.}

Fabian Society : E. Carpenter, T. S. Dyuond, D. C. Pedder. Socialism and Agriculture. Fabian Society, 1908. 6d. net. Gilbeirt, Bernard. Fortunes for Farmers Frank Palmer, 1912 $2 \mathrm{~s}$.

HAgGard, H. R Rural England. Longmans, 1905. 2 vols. 12s. net.

Kropotinn, Prince. Fields, Factorics, and Worlishops. Nelson, 1912. 1s. net.

Masterman, C. F. G. (edited). To Colonise England. Unwin, 1907. 2s. 6rl. net.

Millin, G. F. The Village Problem. Sonnensehein. 2s.6d.net. Moore, H. E. Back to the Land. Methuen. 2s. 6d. Out of print.

Pedder, Lt.-Col. D. C. Where Men Decay ; a Survey of Present Rural Conditions. Fifield, 1907. Is.

Pratr, E. A. Agricultural Organisation. King \& Son, 1912. 2s. 6d. net.

Organisation of Agriculture. King \& Son, 1912. 3s. 6d. net.

Traders, Farmers, and Agricultural Organisation. King \& Son, 1912. 3d. net.

Transition in Agricullure. King \& Son, 1905. 3s.6d. net. Rogens, A. G. L. Business Side of Agriculture. Methuen, 190\%. 2s. 6d. net.

Turnor, Cimistorier. Land Problems and National Welfare. John Lane, 1911. 7s. 6d. net.

\section{WAGES.}

Bowley, A. L. Wages in the United Kingdom in the Ninetecnth Cenlury. Cambridge Press, 1900. 6s. net.

Buxton, C. Roden. Minimum IVages for Agricullural Labouters. Contemporary Review, August 1912; also published as pamphlet by National Land and Hone League. Rowntree, B. Seliboin, and Kendall, Mlay. How the Labourer Lives. Nelsun, 1913.

\section{HOUSING.}

Aduns, T. Garden City and Agriculture. Simpkin, 1905. 1s. net. 
Alden, P., and Hayward, E. E. Housing. Hearlley, 1907. 1s, net.

Allew, J. G. The Cheap Cottage and the Small House. Garden City Press, 1912. 1s. 6ol.

Arosson, H. Our Village IIomes; the Evil and its Remedies. Murby, 1913. 2s. 6d.

Churton, Annette. Hote the Housing and Town Planning Act of 1909 affects Rural Districts. King \& Son, 1910. 2d. net.

Crotcu, Walter. Cottage Homes of England. The ease against the housing system in rural distriets. Industrial Publishing Co., 1908. 1s.

Rural Housing Assocration. Cottages for Rural Labourers. King \& Son, 1909. 4d. net.

Tilomirson, Aldenvian IV. IIousing IIandbook Up-to-Date. King \& Son, 1910. 7s. 6d. net.

\section{SMIALL HOLDINGS.}

Grene, F. E. Awakening of England. Nelson, 1912. 2s. net. Horo I Work . Iy Small Farm. Fifield, 1907. 1s, net.

The Cottage Farm. Daniel, 1912. 1s.

The Small Holding. Lane, 1908. 3s. net.

Inpey, F. Small Holdings in England. Kring \& Son, 1909. 3 d. net.

Pratr, E. A. Small Holders and What They Must Do to Succeed. King \& Son, 1909. 2s. net.

Trвb, Miss L. The Small IIoldings of England: a Survey of Existing Systems. Murray, 1906. 10s.6d. net.

\section{CO-OPERATION.}

Aves, E. Co-operative Industry. Methuen, 1907 5s. net.

Bulstrode, W. Co-operative Farming. P. S. King \& Son, 1908. 3d. net.

Devine, H. C. People's Co-operative Banks. Cassell, 1908. 1s, net.

FAY, C. R. Co-operation at Home and Abroad. P. S. King \& Son, 1908. 10s. 6d. net.

Hobson, J. A. Co-operative Labour on the Land. Sonnensehein, 1895. 2s. 6d.

Wolfe, H. W. Co-operation in Agriculture. King \& Son, 1912. 6s. net.

Co-operative Banking. King \& Son. 1907. 7s. 6d. net. A Co-operative Credit Bank Handbook. King \& Son, 1909. 1s. net.

Pcople's Banks. KFing \& Son, 1909 6s. net. 
LAND (NATIONALISATION, RATING, TAXATION). Adam, Edwin. Land Values and Taxation. Jack, 1907. Is Blunden, G. H. Local Taxation and Finance. Sonnenschein, 1895. (Social Scienee Series.) 2s. 6d.

Cannan, E. History of Local Ratcs in England. P. S. Mringston, 1896. 2s. 6d, net.

Cinomley, C. H., and Outhwaite, R. L. Land Values Taxation in Theory and I'ractice. Sidgwiek \& Jackson, 1909. Is. net. Chonlton, J. D. Rating of Land Values. Manchester University Press, 1907. 3s. 6d. net.

Cox, Harold. Land Nationalisation and Land Taxation. Methuen, 1906. 3s. 6d. net.

Eversley, Lond. Commons, Forests, and Footpaths. Cassell, 1910. 2s. net.

Geongf, Henry. Progress and Poverty. Reeves, 1884. 1s.

Jenis, E. Modern Land Lato. Oxford University Press. 5s.

Lerevre, G. Shaw. Agrarian Tenures in England, Ireland, Scotland, and Recent Reforms. Cassell, 1896. $5 \mathrm{~s}$.

Money, L. G. Cinozza. Riches and Poverty. Methuen, 1910. 5s. net and 1 s. net.

Nicriolson, J. S. The Relation of Rents, Wages, and Profits in Agriculture, and their Bcaring on Rural Depopulation. Sonnensehein. (Soeial Science Series.) 1906. 2s. 6d.

Rates and Taxes as Affecting Agriculture. (Social Scienee Series.) 1905. 2s. 6d.

Orr, Jorn. Taxation of Land Values. P. S. King \& Son, 1912. 1s. net.

PolıLock, Sir F. Land Laros. Maemillan, 1896. 2s. 6d.

Russell, Honourable Rollo. Distribution of Land. IKing \& Son, 1907. 3d. net.

Seligman, E. R. A. Shifting and Incidence of Taxation. Macmillan, 1899. 12s. 6d. net.

Suart, W. Taxation of Land Values and the Single Tax. Maemillan, 1900. Out of print.

Thackeray, S. W. Land and the Community. Kegan Paul, 1889. 3s. 6d. net.

Wallace, Alfred R. Land Nationalisation. Sonnenschein, 1892. 2s. 6d. and 1s.

Webb, Sidney. Grants in Aid. Longmans \& Co., 1911. 5s. net.

Wedgwoon, J. and Mrs. The Road to Freedom and What Lies Beyond. Daniel, 1913. 1s. net.

LAND QUESTION IN OTIEER COUNTRIES.

Baring-Gouln, S. Germany, Past and Present. Paul, 1881. $7 \mathrm{~s} .6 \mathrm{~d}$.

Dumas, Jacques. Present State of Land System in France. Economic Journal. Vol. 19, pp. 32-56. 
Haggard, H. Rider. Rural Denmarli and its Lessons. Longmans, 1911. 6s. 6d. net.

Plunketr, Horace. Rural Problem of the United States. Macnillan, $1910.5 \mathrm{~s}$. net.

Ireland in the Nerv Century. Murray, 1905. 1s. net.

Rowntree, B. Seenory. Land and Labour: Lessons from Belgium. Maemillan, 1910. 10s. net.

Scott, J. W. Robentson. A Free Farmer in a Free State (IIolland). Heinemann, 1912. $6 \mathrm{~s}$.

\section{GAME LAWS.}

The Grouse in Health and Disease. Preface by Lond Lovat. 1912.

WELFonD, R. G. Influence of the Game Lares (Evidence before a Select Committee. Appendix and Address to Tenant Farners by John Briglit). Groombridge, 1846. 3s.

\section{MISCELLANEOUS AND GENERAL.}

Arcir, Josepir. Story of II is Oron Life. Hutchinson, 1897. 6s. Bounne, G. Memoirs of a Surrey Labourer. Duckworth, 1007. $6 s$.

Change in the Village. Duckworth, 1912. 5s.

Cambury \& Bryan. The Land and the Landless. Headlcy, 1908. 1s, net.

Davies, Emi. The C'ase for Railway Nationalisation. Collins, 1913. 1s. net.

Davies, Maud F. Life in an English Village : an economic and historic survey of the parish of Corsley, Wiltshire. Unwin, 1909. 10s. 6d. net.

Davícs, W. H. Autobiography of a Super-Tramp. Fifield, 1908. 6s.

Farrchild, G. T. Rural Wealth and Welfare. Macmillan. 5s. 6d. net.

Fordham, Montagu. Mother Earth: a proposal for the permanent reconstruction of country life. Open Road Publishing Co., 1908. 1s. net.

Grairam, P. A. The Rural Exodus. Methuen, 1892. 2s. 6d.

Green, F. E. The Tyranny of the Country-side. Fisher Unwin, 1913. 2s. net.

Green, J. L. Rural Industries of England. Marlborough Press, 1895. Out of print.

Heati, F. G. British Rural Life and Labour. King \& Son, 1911. 10s. 6d. net.

Heati, R. The English Peasant. Unwin, 1893. Out of print. Mann, P. H. Life in an Finglish Village (Bedfordshire). Sociological Papers, 190t. 
Pratt, E. A. Railuays and their Rates. Murray, 1905. 5s. net. History of Inland Transport and Communication in England. Fing \& Sun, 1912. 6s. net.

Protuero, R. E. English Farming, Past and Present. King \& Son, 1912. 12s. 6d. net.

Quainjance, II. W. Influence of Farm Machinery on Production and Labour. Sonnenschein, 1904. 2s. 6d.

OFFICIAL PUIBLICATIONS, REPOR'TS, ETC.

Final Report of the Royal Commission on Agriculture. Cd. 8510. 1896.

Report of the Departmental Committee on Simall Iloldings. Cd. 3277.1906.

Report of the Departmental Committee on Small IIoldings: Evidence, etc. Cd. 3278. 1906.

Annual Reports of Procesdings under the Small Holdings and Allotments Act, 1908.

Return of the Number of Agricultural IIoldings in each County of Great Britain. Cd. 3708. 1907.

Memorandum of Evidence contained in Parliamentary Papers as to the Demand for Allotments and Sinull IIoldings, and as to the Difficulty of Obtaining Land for these purposes. Cd. 346S. 1907.

Report of the Departmental Committee on Buildings for Small IIoldings in England and Wales. Cd.670s. 1913. 11s. 3d

Annual Reports of the Congested Districts Board for Ireland

Final Report is Cd. 4.088. 1908.

Index to Evidenee. Cd. 4059. 1908.

Digest of Evidenee. Crl. 4099. 1908.

Report on the Decline in the Agricultural Population of Great Britain, 1881-1906. Cd. 3273. 1906.

Report on the Agricultural Returns relating to Acreage and Produce of Crops, and Number of Livestock in Great Britain, with Summaries for the United Kingdom, British Possessions and Foreign Coumtries, and Particulars of Prices, Imports and Exports of Agriculural Produce. Cd. 3061. 1901.

Report on I'rges, Earnings and Conditions of Fimploument of Agricultural Labourers in the United Kingdom. Cd. 34.6, 1900 ; Cd. 2376, 1905.

Report on Earrings and Hours in Agriculturc. Cd. 5460. 1910. Afforestation: Second Report of the Royal Commission on Coast Erosion, Reclamation of Tidral Lauds, and Afforestation in the United Kingdom. Cd. 44.60. 1909.

Correspondence between the Board of Agriculture and Fisheries and the Railzan Companies in Great Britain as to the Carriage of Agricnltural Products and Requisites. Cd. 2045. 1904.

Anmurl Agricultural Returns for Great Britain, with Alstract Returns for Forcign Countries. King. 4 parts. 6d. each. 
Anmual Reports of the Department of Agriculture and Technical Instruction (Ireland).

Aunual General Abstracts showing Acreage undcr Crops, etc.

Amunal Reports of the Crofters' Commission (Scolland). P. S. King.

Royal Commission on the Land Transfer Acts. Second Final Report. Cd. 5ts:3. 1911.

Report of the Tariff Commission (Vol. 3) on Agriculture. King, 1909. 2s. fid. net.

Report of Royal C'ommission on Loral T'axation. Cd. 638. 1896. Report of Roynal Commission on Land Values. Cd. 638. 1907. $1 \mathrm{s.} 6 \mathrm{~d}$.

Land Taxes in Germamy. France, Australia, and the Worting of Taxation of Site Values in cerlain cities in other comntries. Cd. 1750.1909.

Rural Housing.

(W'hite Paper 305 (Local Govermment Board).

Second Report of Development Commissioners. H.C. 305. March, 1912

White Paper, 293 (Local Gozermment Board). August, 1912. IIousing Section Report of the First National Conference on the Prevention of Destitution, 1911. King \& Son, 1911. 2s. 6d. net.

IInusing. See Paper in Report and Proceedings of Second National Conference on Prevention of Dcstitution, Housing Section. P. S. King \& Son, 1912. 10s. 6d. net.

Rural Dctelopment and Sinall Holdings. Official Report of the Conference of the Small IIoldings Section of the Festival of Empire, 1911 (with an Address by Earl Carrington), 1912 King \& Son. 2s, net.

lBoard of Agriculture Leaflets, Nos. 214, 218, 260, on Cooperation and Credit Banks.

lieport of the Sclect Committee of the House of Lords on the Thrift and Credit Banks Bill, 1910.

Farming in Dermarli. A Report of the Scottish Commission to Dcumark, 1904. Blackwond \& Son. 6d.

lieport on Co-operatize Agriculture and Rural Conditions in Denmarli (by a Deputation from the Department of Agriculture and Technieal Instruction for Ireland), 190.t. Alex. Thom \& Co., Dublin.

Report of Departmental Committee on the Frrit Iudustry of Great Britain, 1905.

Training. Report of First National Conference for Prezention of Destitution. Paper by Bolton Smart on Hollesley Bay. King, 1911. 10s. 6d. nct.

Agricultural Organisation Society-Anmual Reports.

Journal of the Board of Agriculture.

Acreage and Live Stock Returns, Agricultural Statistics, 1912. cd. 6597. 
Census of England and Wales, 1911. Vol. I. Cd. 6258. 1912. 5s. 4 d. net.

Fifteenth Abstract of Labour Statistics (Board of Trade). Cd. 6228. 1912.

Report of the Selcet Committce on the Housing of the Working Classes Acts Amendment Bill, 1906. H.C. 376. 1s.

Report of Royal Commission on Agricultural Depression, 1897. Cd. 8540. 3s. 1 d.

Annual Report of the Small Holdings Commissioners. Published May, 1913. Cd. 6790. 5d.

Monthly Bulletins of International Institute of Agriculture (Rome). Report on Working of Small IIoldings and Allotments Act, elc., for 1911.

Statistical Abstract relating to British India from 1901-02 to 1910-11. Cd. 6637. 1913.

Scottish Census Returns, 1911.

Railway Rates (Preferential Treatment). Cd. 2959. 5d.

Railway Rates and Frailities. Cd. 2045. 10d. 


\section{INDEX}

Acreage of England and Wales, 1 of agrieultural land, 1 Acres per labourer, Appendix G Afforestation, Report of Royal Commission on, 105

must be undertaken by State, 105

necessary part of rural development, 106

in other countries, 105

Agrarian banks, 85

Agriculture, Women engaged in, 13

Persons engaged in, 2, 3, 4

Decline of, 1, 2

Negleet of, 5, 6

Replaced by industry, 5

State development of, 25

Output of, 1, 58,$54 ;$ Appendix A

Agricultural Credit and Insurance

Societies Bill, 1910, 84

Agricultural Instructors, Travelling,

71,72

Agricultural Labourers, Decrease

in numbers of, $2,8,4$

Scareity and dependence of, $4,5,55$

Poverty of, $7,8,9,10,11,12$,

$13,14,15,16,17,55$

Organisation of, 27

IVages of, $7,8,9$

Hours of labour of, 9, 10, 11

Budgets of, $13,14,15,16$

Family earnings of, 12, 13

Agricultural Land, Aereage of, 1

Output of, 1, 54; Appendix A

Agricultural Organisation Society, $74,75,76,77,78,84,85$

Opposition to, 77

Articles of Association of, 77; Appendix K
Agricultural Schools, 71, 72

Allen, G. Gordon, 39

Allotments, Appendix D

distance from cottages, 12

Allotments and Small Holdings

Act, 1908, 69

America, 5, 71, 91

Anglesey, 89

Argentine, Co-operative dairies and factories in the, 82

Armistead, Dr., 21

Aronson, Hugli, 19

Ashford, 92

Austria, Co-operation in, 74

Co-operative dairies and factories in, 81

freights to, 91

pereentage of land covered witl trees in, 105

Banks. See Credit Banks

Barclay, T. W., M.P., 92

Bathurst, Chas., M.P., 70

Bavaria, 9.5, 96

Bedford, 14

Bedfordshire, 8, 11, 19

Bedrooms, dearth of, 19, 20, 21

Belgium, 42, 54, 74

Co-operative purchase in, 79

Pereentage of land covered with trees in, 105

Raiffeisen Banks in, 85

Belloc, Hilaire, 56

Belts of agricullural land round torens, 47

Biffen, Professor, 71 ; Appendix J

Biggleswade, 19

Billericay, 19

Birmingham, 92, 95 
Board of Agrieulture and Fisheries, $76,77,84,92,106$

of Trade, 76

National Minimum Wage, 28, 29,30

Boards, Loeal Minimum Wage, 28, $29,30,31$

Boulogne, 92

Boy Labour, 12

Bradford, 93

Bray, R. A., L.C.C., 103

Brighton, 89

Bristol, 89, 9.4

Brittany, 92

Buckinghamshire, 10, 23, 27

Budgets of agricultural labourers, $13,14,15,16$

Building of eottages, 24, 36, 37, 38, $39,40,41,42,43$

Effeet of coal strike on cost of, 39

Bullen, Mr., 95

Buying and leasing land for small holdings compared, 57,58

Bye-laws, Inelastic, 38

\section{California, 91}

Cambridge, Mendelian experiments at, 71 ; Appendix J

Canterbury, 92

Carmarthen Farmers' Co-operative Society, 80

Carmarthenshire, 108

Carrington, Earl, 49

Casual labour, 8

Cattlemen, 7, 9, 10

Caxton and Arrington (Poor Law) Union, 111

Census of persons engaged in agriculture, 2,3

of women engaged in agriculture, $1: 3$

of urban and rural areas, 3,4 of Cerne Abbas, 4

Central Land Association, 70

Cerne Abbas, 4

Charente District, 81

Cheshire, 58

Clyndermen and District Farmers' Association, 80
Coal Mines Act, 29, 30

Coal Strike, effect on cost of building, 39

Commons, Enelosure of, 52, 53

Co-operation, Reeent growth in Lingland, 73

Grant for promotion of, 75 essential for small holder, 88 effect on farmers, 67 abroad, 74

in England and Wales, 74

in Ireland, 75

possibilities of, 78

Co-operative bacon factories,

in Denmark, 82, 83

in England, 83

Co-operative dairies and factories, $80,81,82,83$

in Denmark, 80,81

in Franee, 81

in Holland, 81

in Hungary, 81

in Austria, 81

in Sweden, 81

in Argentina, 82

in Norway, 82

in Germany, 82

in Ireland, 82

in England, 82

Co-operative marleting, $87,88,89$, 90,91

in Denmark, $90 ;$ Appendix $\mathbf{L}$ in France, 90 ; Appendix L

in England, 90, 91

Co-operative Purchase, 78, 79, 80

in Denmark, 78

in Germany, 78

in Franee, 78,79

in Belgium, 79

in Poland, 79

in Italy, 79

in Holland, 79

in Sweden, 79

in Hungary, 79

in Switzerland, 79

in Finland, 79

in England and Wales, 79, 80

Co-operative Union, 77

Cork, County, 41

Cornzuall, 4, 18, 53, 89

Cost of building eottages, 38,39

of Edueation in U.S.A., 71

of living, 13, 14, 15, 16, 17 
Cottages, 17, 18, 19, 20, 21, 22, 23, $24,36,37,38,39,40,41,42$, 4.3

Dearth of, 20, 21, 22, 28

Government grant in aid of building, arguments for and against, $40,41,42$

lixample of Ireland, 40, 41

Stimulus to local authorities, 42,48

Insanitary condition of, 21, 22, 2:3

Overerowding of, 19

Tied, 12

too small, 21

Collage-building, Cost of, 38, 39

Loans to IR.D.C.'s, 37

not a commercial undertaking, 24, 38, 39

Price of land unimportant factor in, 38

Cost of labour in, 38

Minimum wage a stimulus to, 41

Housing of Labouring Classes Act, 1890,36

Housing and Town-Planning Act, 1909,36

County Councils, Administration of Minimum Wage Act by, 30, 31

Connty Councils' Association, 77, 110

Courie, 99

Credil Banl's, 83, 84, 85, 86

liability of nembers, 8 ;

Cromarlie, Countess of, 99

Crowland, 19

Cumberland, 9, 26, 28

Cunningham, W., 91

Dairies. See Co-operative Dairies Dairy farming, Extension of, 4

Davics, Emil, 91

Davies, Miss Maud, $7,9,13,15$

Dearth of bedrooms, 19,21

of cottages, $19,20,21,23,24,38$

Death Duties on land, 46, 51

Decline of agrieulture, 1, 2

of sentimental value of land, $45,46,51$

Decrease in number of agrieultural labourers, 2, 3, 4

in value of money, 16,17
Deductions from wages, 10

Development Conmissioners, Grant for promoting agricultural co-operation by, 76

Grant to A.O.S., 76,84

Devon, 53

Displacement of labour by laying down land to grass, 4, 45

by machinery, 4

Doncaster, 93

Dorsetshire, 7, 9, 10, 17, 26, 32

Dover, 94

Driffield, 93

Drudgery of agricultural labourers, 4.

Dundee, 93

Durham, 33, 111

East Anglian Farmers, Ltd., 90

Eastern Counlies Farmers' Association, $79,80,8 ;$

Educalion, Cost of, in U.S.A., 71

Rural, $70,71,72$

at Lindsey, $r 1$

effect on Farmers, 70,71

Unsuitability of, 70

Suggested reforms in, 71, 72

Edwards, George, 8

Eight hours' day, 10

Enclosure of Commons, 52, 53

Essex, 53, 108

Family earnings of labourers, 11, 12,13

Farm sehools, 71, 72

Farmers, Effect of co-operation on, 67

of edueation on, 70,71

of land tenure on, 67,68

of local taxation on, $6 \tau$

of mininum wage oll, 32, 33, 34,66

of railway rates on, 92,93

of organisation of marketing on, 67

of organisation of transit on, 67

Lack of edueation among, $70, \tau 1$

Farming, Uneconomical, 4.5

Farms, Value of tenant, $\Lambda$ ppendix $\mathrm{H}$

Fels, Josepl, 64, 65 
Females in agrieulture, 2

Feudalism, 44

Finland, 74, 79, 82

Flushing, 91

Folkestone, 91, 92, 94

Framlingham and District Farmers' Co-operative Association, so, 91

France, Co-operative dairies in, 81 marketing in, 90 ; Appendix L

purehase in, 78,79

Percentage of land covered with trees in, 105

Raiffeisen banks in, 85

Fylde (Poor Law) Union, 111

Galway, County, 92

Game Laws, Abolition of, 101, 102 Summary of, 101, 102

Game-preserving, 5, 97, 98, 99, 100, 101

Advantages of, $97,98,99$

Evils of, 99, 100, 101, 102

Expenses, 98, 99

Reduetion in value of farms owing to, 100

Tax on, 103, 104

Gardens, Lack of, 12

Germany, 42, 54, 61, 63, 74, 78, $82,85,86,91,94,96,105$

Co-operative purchase in, 78 dairies in, 82

Pereentage of land covered with trees in, 105

Raiffeisen banks in, 85

Gilmour, W. E., 99

Gladstone, Mr., 95

Glasgow, 94

Goole, 93

Gosehen, Lord, 49

Gothenburg, 81

Grantham, 20

Grants in aid of bnilding cottages, $40,41,42,43$

rates, $109,110,111$

by Development Commissioners, 76,77

to $\Lambda$.O.S., 76,77

Government Housing, in Ireland, 40, 41

Great Western Railway, 95

Grimsby, 94
Grouse Moors, Expenses of, 98, 99 Sporting rents of, 98

Guildford of Mid-Surrey Farmers Agricultural Co-operative Association, 80

\section{Hamburg, 95}

II ampshire, 9, 11

Ilarvest-money, 8

IIarwich, 94

Hasbach, Dr. W., 13

IIcalth, 19, 20, 21, 22

Henncll, Mr., 95

Herefordshire, 4

IIerifordshire, 21, 27

Hirst, $\boldsymbol{F}$. W., 2

IIolidays, 10

Holland, 42, 74, 79, 81, 85, 91

Co-operative purchase in, 79

Co-operative dairies in, 81

Raiffeisen banks, 85

Horsemen, 7, 9, 10

Hours of labour of agricultural labourers, 9, 10, 11, 30

Houschold Budgets, 13, 14, 15, 16

IIousing grants, 40, 41, 42, 43

IIuddersfield, 93

IIull, 93, 94

IIungary, Co-operative purchase in, 79

dairies in, 81

Percentage of Land eovered with trees, 105

Raiffeisen banks, 85

Importation of timber, 105

India, Raiffeisen banks in, 86, 87

Industrial Revolution, Cause of decline of rural life, 5

Cause of long hours of labour, 10,11

Industry, Output of, 1 ; $\Lambda$ ppendix $\Lambda$

replaced by agrieulture, 5

Inhabited IIouse Duty, Transfer to local exchequer, 109

Insanitary cottages, 21, 22, 23

Instructors, Travelling Agrieultural, 71, 72

International Institute of Agriculture (Rome), 74 
Ireland, Government housing grants in, 40, 41

Agricultural co-operation in, 75

Co-operative dairies in, 8:2

Percentage of land covered with trees in, 105

IRaiffeisen banks in, 85

Cottage-building in, 40,41

Irish Agricultural Organisation Society, 75

Irredcemable Morlgage, Thc, 50, 51

Italy, 74

Co-operative purchase in, 79

Raiffeisen banks in, 85

Japan, 74

Johnson, A. H., 53

Julland, West, 80, 81

Karchave School, 72

Kent, 53

King's Lynn (Poor Law) Union, 111

\section{Labourer. See Agricultural} Labourers

Lamb-money, 8

Lancashire, 9

Land, Acreage of agricultural, 1 put to seliish uses, 5,38

Uneconomical farming of, 4.5

Taxation of, 25, 47, 109

Death duties on, 46,51

Sentimental value of, $4.4,45,46$, 51

Nationalisation of, $4 \%, 51$

Land Commissioners, $48,49,50$

Land stock, Guaranteed, 49

Land tenure, $67,68,69$

Landlord, Effect of minimum wagc on, 34, 3.5

Lapland, 79

Leeds, 93

Leicester, 82, 93

Leith, 94

Levy, Prof. IIermann, 53

Limpsfield, 58

Lincolnshire, 9, 18, 32, 58, 72 Marquis of, 49
Lindsey, 58, 71

Linton, 21

Little, W. C., 18

Liverpool, 71,93

Loans to R.D.C.'s for cottagebuilclinır, 37

Local Goverument Board, 75

Local 'Taxation, 67, 108, 109, 110 , 111

London, Port of , 49, 58, 89, 91, 94

Longforen (Poor Law) Union, 111

Lovat, Lord, 98

Machinery, Displacement of labour by, 4

Malmö, 82

Manchester, 92, 93

Mann, P. H., 8, 13, 14, 15

Marures, Compound, 70, 71

Market gardening, Extension of, 4

Marketing, Co-operative, 26, 87 , $88,89,90,91$

Marliets, Insufficiency of, 89

Marriage of labourers, Early, 13

Marshall, William, 10

Mayland small holdings expcriment, 64, 65

Medical Officers of Ilealth, Reports of, $19,20,21,22$

Mendlclian experiments at Cambridge, $\mathbf{7 1}$; Appendix J

Merton, Statute of, 52

Middlemen's profits, 88

Middlesex, 8, 111

Midland Conties Agricultural Traders' Association, 95

Midland Farmers' Co-operatize Association, 80

Milk, Scarcity of, in rural districts, 87

High price of, in England, 87, 88

Price of, in Denmark, 88

Minimum Wage, arguments for National rate, 27

Boards, local and national, 28, $29,30,31$

same for all grades of workers, 27,28

stimulus to cottagc-building, $40,41,4: 2$

Effect of, on farmers, 32, 33, 34,66 
Minimum Wage, Effect of, on landlord, 34, 85

Machinery of, 28, 29, 30, 31

in mining industry, 25, 29,30

Mining industry, minimum wage in, $25,29,30$

Money, Decrease in value of, 16 , 17

Money, L. G. Chiozza, M.P., 17, 45,93

Monmouth, 108

Molor service, State, 96

Munro, A. W., 92

Nationalisation of land, $4,7,49,51$ of railways, $91,92,93,94,95,96$

Newcaslle, 94

Nezhaven, 94

Nezeport (Salop) and District Agricultural Trading Society, 80

Nezo York, 93

Norfolk, 7, 10, 18, 20, 58

Chamber of Agriculture, 91

Normandy, 91

Northumberland, 21, 57

Norway, Co-opcrative Dairies and Factories in, 82

Organisution of markets, 26, 67, $87,88,59,90,91$

of transit, $67,91,92,93,94,95$, 96

Ourdle, 20

Output of agricultural land and industry, 1, 54; Appendix A

Overcrowding, 19

Ownership lyy farmer, 66, 67, 68 by small holder, $67,68,69$ Tenaney versus, $66,67,68,69$

Oxfordshire, $7,8,32$

\section{Pembrokeshire, 108}

Pershore Co-operative Fruit Market (Lld.), Worcestershire, 90

Plunkett, Sir Horace, 5, 75, 82

Poland, Co-operative purchase in, r9

Population of urban and rural districts compared, $\mathbf{3}, \mathbf{3}$; decrease in rurul districts, $2,3,4$

Porter, G. R., 2
Portsmouth, 11

Prall, Edwin A., 68, 78

Price of building materials, 39 ; Appendix I

of lind, 38

of milk, 87,88

of wheat, 53; Appendix J

Prussia, 1Railway rates in, 94

Queenborough, 91

Radnorshire, 4, 91

Raiffeisen banks, 78, 85, 86, 87

Definition of, 85

in Belgium, 85

in England, 86

in France, 85

in Germany, 85

in Holland, 85, 86

in Hungary, 85

in India, 86, 87

in Ireland, 85

Railway nationalisation, 91, 92, 93, 94, 95, 96

Railway Rales injurious to farmers, $91,92,93,94,9.5,96$

preferenec given to foreigners, $91,92,93,94$

complieations of, 94

Rates Grants in aid of, 109, 110 , 111

lower now than $\mathbf{1 0 0}$ years ago, 108

Fear of increasing, 108, 109

Rating system contributory cause of dearth of cottages, 38

Rent of cottages, 17, 18, 38, 39

of small holdings, 39

of tenant farms, 34, 35; Appendix II

Rent conrts, :4

Ridgmount, 14

Rozontree, B. Secbohm, 13, 54

Royal Commission on railways, 93 on alforestation, 105

Rural arers, census of, 1, 2, 3, 4

Decrease in population of, 2 , 3,4

Rural District Councils, Loans to, 3 \%

Russell, G., 75

liussia, Afforestation in, 105 
Schools, Farm, 71, 72

Smallholders', in Denmark, 72

Scotland, Percentage of land eovered with trees in, 105

Scottish Congested Districts Board, 99

Department of Agriculture, 99

Security of tenure, 60

Selby, 9:3

Servia, 74, 79, 105

Shepherds, Wages of, $\tau, 9$

Single Tax, The, 47

Site values of rural land, 109

Small holder, Qualities essential to success of, 63

Small holdings, Advantages of, 54, 55,56

Demand for, 58

High rents of, 59

Effect on village of, 5.5, 56

Eeonomic argument for, 52, 53,54

tenaney versus ownership, $6 \tau$, 68,69

Small IIoldings and Allotments ifct, 1908, 57

Working of, 57,58

Powers of, 75

Comparative failure of, $59,60,61$

Somerset, 10, 18, 58

Southampton, 94

Southern Countics Agricultural Trading Society, 80

Storve, 89

Suffolli, 7, 9, 33

Surrey, 106

Sussex, 18, 108

Siceden, Co-operative purchase in, 79

Co-operative dairies in, 81,82

Pereentage of land covered with trees in, 105

Sicitzerland, Co-operative purchase in, 79

Syndicat Centrale des Agriculteurs de France, 79

\section{Tariff Reform, 25}

Tawney, R. H., 53, 55

Taxation of land, 25, 4\%, 109

of game-preserving, 103, 104
Tenancy versus ownership, 66, 67, (is, 69

of farmers, 67,68

Tenure of small holder, $67,68,69$

of farner, $66,67,68,69$

Security of, $6(6,6)$

Thompson, Alderman, 18, 21

Thrift and Credit Banlis Bill, 8.4

Timber, Importation of, 105

Tobacco growing, 75

Trade Unions for Agricultural Labourers, 26, 27, 31

Travelling agricultural instructors, 71,72

Turnor, Christoplier, 32, 45, 54, 88,100

Tyramies of village life, 23,24

Unearned increment on rural land, Taxation of, 109

Utrecht, 86

Valuation of land, $47,48,49,50$, 51

Value of money, Decrease in, 16, 17

I'uyst, M., 54

Wages of agricultural labourers, T, 8,9

Boards, 28, 29, 30, 31

Rise in, 17,25

Higher, result in better work, 32

See also Minimum Wage

Warvickshire, 11

IVebb, Sidney, 10S, 110

Wells, H. G., 5.;

Hest Midland Farmers' Association, 80

Westmorland, 9

Wheat, Fall in price of, 53

Wiltshire Farmers, Ltd., 82, 90

Women in agriculture, 2, 13

Worcestershire, 57

Wye, 92

York, 15

Yorkshire, 9

Zola, Emile, $6 \mathrm{~s}$ 


\section{Fabian Research Department Publications}

The Fabian Researeh Department was formed in 1912 for the purpose of systematising the researeh into social problems, whieh has always been a part of the work of the Society.

The first fruits of this step is the present Report on the Rural Problem.

The next Report, now being drafted by Mr. and Mrs. Sidney Webb, will treat of the "Control of Industry" and will be published in 1914, and an investigation into the operations and sphere of Industrial Insuranee is now being set on foot.

The Fabian Researeh Department has its own offiees and staff and its expenses are defrayed by speeial funds contributed in part by non-members interested in investigation rather than propaganda. Membership in the Rescareh Department is open to all members of the Society, and any others willing to give help may be co-opted as associates.

For further information apply to the Fabian Society, 3 Clement's Inn, Strand, London, W.C., or the Fabian Researeh Department, 37 Norfolk Strect, Strand, London, W.C.

Oetoher, $191 \%$. 


\section{THE FABIAN SOCIETY.}

THE FABIAN SOCIE'TY consists of men and women who are Soeialists, that is to say, in the words of its "IBasis," of those who aim at the reorganisation of society by the emancipation of Land and Industrial Capital from individual and elass ownership, and the vesting of them in the eommunity for the general benefit... For the attainment of these ends the Fabian Society looks to the spread of Socialist opinions, and the soeial and politieal ehanges consequent thercon. It secks to promote these by the general dissenination of knowledge as to the relation between the individual and society in its economic, ethical, and politieal aspects.

The Society weleomes as members any persons, men or women, who desire to promote the growth of Socialist opinion and to hasten the enaetment of Socialist measures, and it exacts from its members no pledge exeept a declaration that they are Soeialists.

The Soeiety is largely oceupied in the endeavour to discover in what way the prineiples of Socialism can be applied both to the political problems which from time to time come up for settlement, and to those problems of the future which are as yet rather politieal theory than actual polities. It holds fortnightly meetings for the diseussion of papers on such subjects by members and others, some of which are published as Fabian Tracts.

The Researeh Department, largely maintained by special funds, investigates partieular problems, sueh as the future Control of Industry, and the IRural Problem dealt with in this Report; assistanee, both personal and finaneial, is invited for this branch of the Society's work from those who are not prepared to take part in the direct propaganda of Socialism.

The Society includes :

I. Menibers, who inust sign the Basis and be elected by the Committee. Their subscription is not fixed; each is expected to pay according to his means. They control the Society through their Exeeutive Committec and at business meetings.

II. Associatis, who sign a form expressing gencral sympathy with the oljeets of the Soeiety, and pay not less than 10s. a year. They ean attend all exeept specially private nectings, but have no control over the Socicty and its policy.

III. Subscribers, who must pay at least 5s. a ycar, and can attend the lectures.

The monthly paper, Fabion Newe, and the Fabian Tracts are sent as published to all three elasses.

Lists of Publications, Annual Report, Form of Application as Member or Associate, and any other information can be obtained on application, personally, or by letter, to

Tire Secretary of tilf Fabian Society, 3 Clement's Inn, Strand, London, W.C. 


\section{Publications of the Fabian Society.}

\section{FABIAN BOOKS, ETC.}

Fabian Essays in Socialism. Seven Essays giving. a conıprehen-

- sive account of the Theory of Socialism. Preface by the Editor, Berinard Siraw. Paper, 6d. net; cloth, .1s. 6d.

Fabian Tracts, Bound. Complete set of those in print.' 1 vol. Buckram, 4s. 6d. net; postage $6 \mathrm{~d}$.

What to Read on Social and Economic Subjects. A classified list of the best books on subjects important to the progressive politician and social student. 1910. Interleaved, 1s. net; cloth, 2s. net.

Songs for Socialists. A collection compiled for the use of Socialist gatherings. 3d. ; post free, 4 d.

\section{FABIAN TRAC'TS}

No. 146. Socialism and Superior Brains. A Reply to Mr. Mallock. By Bernard Silaw. 1 d.

No. 149. The Endormient of Motherhood. By II. D. HAruen. $2 d$.

No. 137. Parish Councils and Village Life. An account of what Parish Councils have done. $\mathbf{1}$ ().

No. 76. Houses for the People. Explanation of the Housing Acts, 1890-1909. $1 \mathrm{~d}$.

No. 62. Parish and District Councils: What they are and what they can do. $1 \mathrm{~d}$.

No. 162 Famıly Life on $£ 1$ a Week: Working-class Budgets explained. By Mrs. Penisiz Rlinvis. 2 d.

No. 51. Socialism True and False. By Sidney Wemb. Id.

No. 42. Christian Socialism. By the REv. STEwakT D. HeanLAM. Id.

No. 161. Afforestation and Unemployment. By A. P. Greviei.I. $1 d$.

No. 170. Profit-sharing and Co-partnership. 13y Epw. R. PEase. $1 \mathrm{~d}$.

Catalogue of about 80 'Tracts still in print and of other publications can be obtained on application to

Tile Fabian Society,

3 Clement"s Inn, Strand,

Lowdon, W.C. 

THE UNIVERSITY LIBRARY

This book is DUE on the last date stamped below 


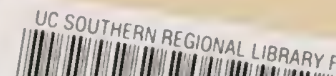 AA 000 | I ||| || ||| || ||||| || $000278137_{5}$}

IDD

1925

다 
6.t.

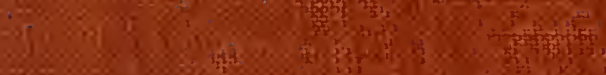

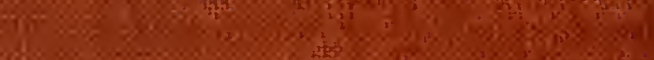

135

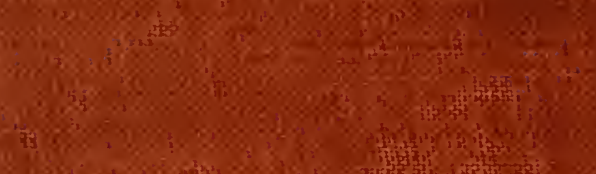

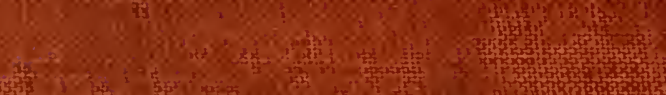

(3)

$=\mathbf{i}$

$3 \times 380$

1
1

trit,

1.7.

wi: :

1.

H.

F,

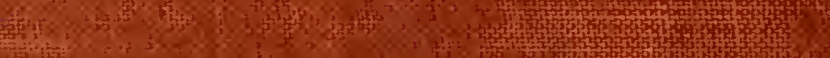

intip

M.

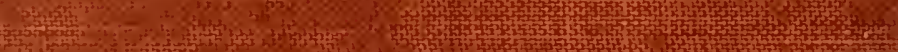

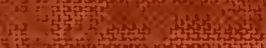

H.

is

6.

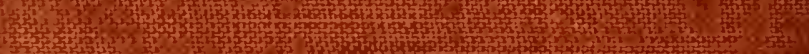

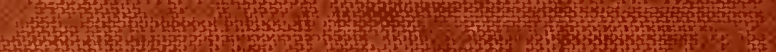

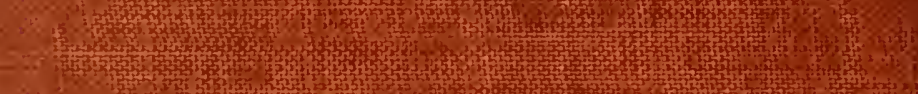

3.

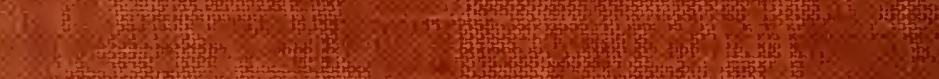

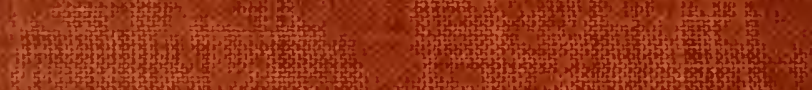

S

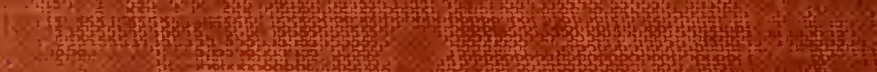

A

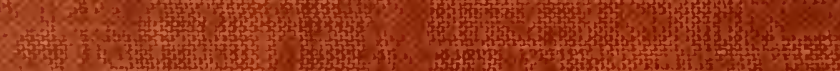

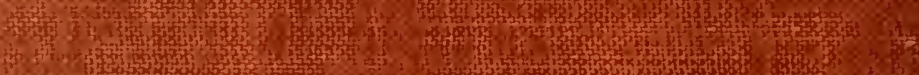

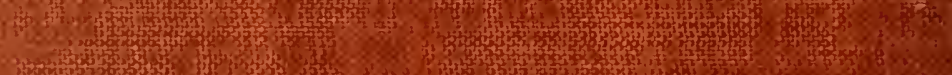

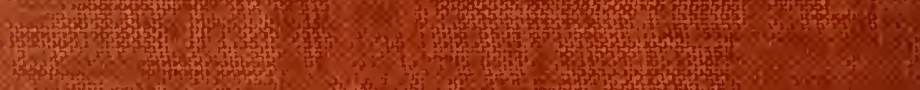

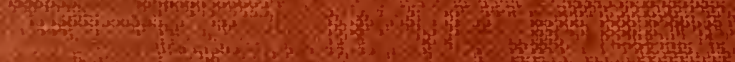

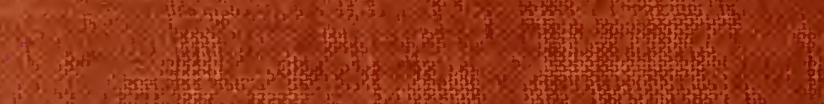

3rit

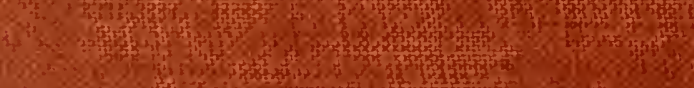

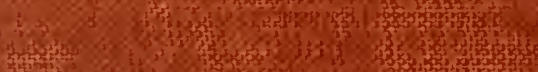

36.

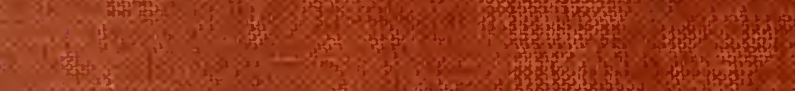

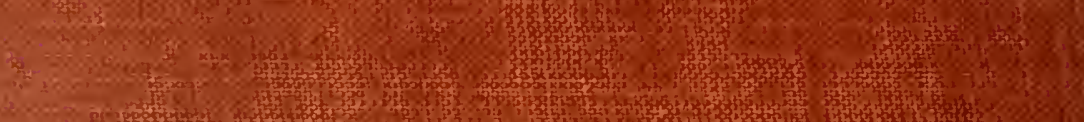

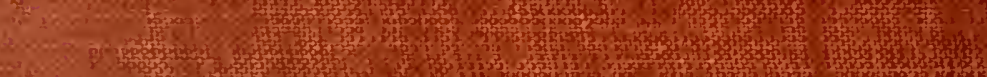

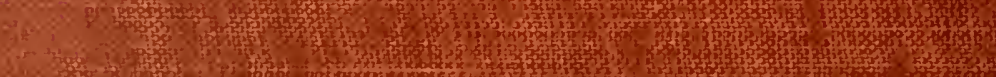

